\title{
Francis Poulenc: The Compositional Influences of Les Six and Sergei Prokofiev on the Poulenc Oboe Sonata (1962)
}

\author{
Evan Klein \\ West Virginia University, eklein2@mix.wvu.edu
}

Follow this and additional works at: https://researchrepository.wvu.edu/etd

Part of the Music Performance Commons

\section{Recommended Citation}

Klein, Evan, "Francis Poulenc: The Compositional Influences of Les Six and Sergei Prokofiev on the Poulenc Oboe Sonata (1962)" (2021). Graduate Theses, Dissertations, and Problem Reports. 10296. https://researchrepository.wvu.edu/etd/10296

This Dissertation is protected by copyright and/or related rights. It has been brought to you by the The Research Repository @ WVU with permission from the rights-holder(s). You are free to use this Dissertation in any way that is permitted by the copyright and related rights legislation that applies to your use. For other uses you must obtain permission from the rights-holder(s) directly, unless additional rights are indicated by a Creative Commons license in the record and/ or on the work itself. This Dissertation has been accepted for inclusion in WVU Graduate Theses, Dissertations, and Problem Reports collection by an authorized administrator of The Research Repository @ WVU.

For more information, please contact researchrepository@mail.wvu.edu. 
Francis Poulenc:

The Compositional Influences of Les Six and Sergei Prokofiev on the Poulenc Oboe Sonata (1962)

\section{Evan Klein}

Research Project submitted

to the College of Creative Arts

at West Virginia University

in partial fulfillment of the requirements for the degree of

Doctor of Musical Arts

in

Oboe Performance

Cynthia Anderson, MM, Chair

John Weigand, DMA, Research Advisor

Mikylah Myers, DMA

Willam Haller, DMA

Allison Helm, MFA

School of Music

Morgantown, West Virginia

2021

Keywords: Francis Poulenc, Sergei Prokofiev, Les Six, Keith Daniel, Pamela Poulin, Margaret

Grant, Siobhán Ciulla, oboe sonata, oboe, neoclassicism

Copyright 2021 Evan Klein 


\begin{abstract}
Francis Poulenc:

The Compositional Influences of Les Six and Sergei Prokofiev on the Poulenc Oboe Sonata (1962)

\section{Evan Klein}

This research document contextualizes the compositional influences found within Francis Poulenc's oboe sonata. In his lifetime, Poulenc was an extremely well-connected individual, often dedicating his works to his close friends and patrons. The Sonata for Oboe and Piano, in particular, is one of these compositions dedicated to his friend and famous composer Sergei Prokofiev. Written in 1962 toward the end of Poulenc's life, he glanced back to the start of the twentieth century for inspiration and source material. The oboe sonata is then a collage of sorts - it takes on the shared contextual principles of Les Six in which he was a member, direct thematic material from Sergei Prokofiev, and self-quotations of his other two late works for winds. This document explores these influences and attempts to source the thematic and extramusical elements found within by performing a comparative analysis using research compiled from Poulenc scholar Keith Daniel, theorist Pamela Poulin, and feminist scholar and oboist Margaret Grant. The document also explores a subsequent "Poulencien" influence on modern neoclassical oboe settings by reviewing oboist Siobhán Ciulla's research document, "Two Examples of Neo-Classicism in France from the Early and Late Twentieth Century: Francis Poulenc's Trio for Oboe, Bassoon, and Piano (1926) and Jean Françaix's Trio for Oboe, Bassoon, and Piano (1994)." Finally, this research document aims to aid performers in actualizing a better understanding of Poulenc's oboe sonata that can translate into a more authentic performance.
\end{abstract}




\section{Acknowledgements}

I want to express my deepest thanks to Professor Cynthia Anderson, my family, and my committee for pushing me to finish my DMA degree over the course of a decade-long journey. 


\section{Table of Contents}

$\begin{array}{ll}\text { Abstract } & \text { ii }\end{array}$

Acknowledgements

Table of Contents

List of Figures $\quad$ v

$\begin{array}{ll}\text { Introduction } & 1\end{array}$

$\begin{array}{ll}\text { Chapter } 1 & 3\end{array}$

The Early Years

Tutelage: Viñes, Satie, and Others

Growing Popularity 17

$\begin{array}{ll}\text { Chapter } 2 & 21\end{array}$

Les Six and First Collaborations

Their Different Styles $\quad 23$

A List of Their Oboe Works

$\begin{array}{ll}\text { Chapter } 3 & 34\end{array}$

The Oboe Sonata (1962-1963)

The Dedication to Sergei Prokofiev $\quad 41$

Prokofiev's Early Style $\quad 43$

Analyses Review $\quad 48$

Wind Sonatas Review

Élégie $\quad 62$

$\begin{array}{ll}\text { Scherzo } & 67\end{array}$

Déploration $\quad 72$

$\begin{array}{ll}\text { Chapter } 4 & 77\end{array}$

A Lasting Legacy

The Neoclassic Expectation

$\begin{array}{ll}\text { Oboe Characterizations } & 81\end{array}$

$\begin{array}{lr}\text { Chapter } 5 & 83\end{array}$

Conclusions

$\begin{array}{lr}\text { Bibliography } & 85\end{array}$ 


\section{List of Figures}

1 Prokofiev, Piano Sonata No. 5, Mvt. I, opening 52

2 Poulenc, Flute Sonata, Mvt. I, opening 52

$3 \quad$ Poulenc, Clarinet Sonata, Mvt. I, reh. 2-3 53

$4 \quad$ Poulenc, La voix humaine, reh. 107-108 (near the ending) 54

$5 \quad$ Poulenc, Flute Sonata, Mvt. II, pickup to 4 before reh. 1

$6 \quad$ Poulenc, Dialogues de Carmélites, act III, scene iii, pickup to 4 before reh. $39 \quad 54$

$7 \quad$ Poulenc, Flute Sonata, Mvt. I, opening 55

$8 \quad$ Poulenc, Clarinet Sonata, Mvt. II, ending 55

9 Prokofiev, Piano Sonata No. 4, Mvt. I, opening 56

10 Poulenc, Flute Sonata, Mvt. I, 3 bars before reh. 3 (piano part) 56

11 Poulenc, Flute Sonata, Mvt. I, ending 56

12 Poulenc, Flute Sonata, Mvt. III, pickup to reh. 9 and 2 bars after reh. 9

13 Poulenc, Clarinet Sonata, Mvt. III, opening 58

14 Prokofiev, Piano Sonata No.4, Mvt. III, opening 58

15 Poulin, "Self-Quotation In The Sonata For Oboe And Piano, example 2-30" 60

16 Poulenc, Oboe Sonata, Mvt. I, opening 63

17 Poulenc, Clarinet Sonata, Mvt. II, opening 63

18 Poulin, "Form Of The Sonata For Oboe And Piano, figure 2-9" 63

19 Poulenc, Oboe Sonata, Mvt. I, reh. 4

20 Poulenc, Oboe Sonata, Mvt. I, reh. $6 \quad 64$

21 Poulenc, Clarinet Sonata, Mvt. I, reh. $8 \quad 64$ 
22 Liturgical chant, Dies irae $\quad 65$

23 Poulenc, Oboe Sonata, Mvt. I, reh. 6, Dies irae notes 65

24 Poulenc, Oboe Sonata, Mvt. I, 2 bars after reh. $8 \quad 66$

25 Poulenc, Clarinet Sonata, Mvt. II, 3 bars after opening 66

26 Poulenc, Clarinet Sonata, Mvt. III, 2 bars after reh. $9 \quad 66$

27 Poulin, "Form Of The Sonata For Oboe And Piano" revised by Klein 66

28 Poulenc, Oboe Sonata, Mvt. I, ending $\quad 67$

29 Daniel, rondo ABA ternary form chart $\quad 68$

30 Poulin, "Form Of The Sonata For Oboe And Piano, figure 2-9" 68

31 Daniel, "rondo ABA ternary form chart" revised by Klein 69

32 Poulenc, Clarinet Sonata, Mvt. I, reh. 9

33 Poulenc, Oboe Sonata, Mvt. II, 7 bars after reh. 3

34 Prokofiev, Romeo and Juliet Suite No. 2, Mvt. I, reh. 7

35 Poulenc, Sonata, Mvt. II, reh. $8 \quad 70$

36 Poulenc, Oboe Sonata, Mvt. II, 4 bars after reh. 9-12 71

37 Poulenc, Oboe Sonata, Mvt. III, opening 73

38 Poulin, "Form Of The Sonata For Oboe And Piano, figure 2-9" 73

39 Poulin, "Form Of The Sonata For Oboe And Piano," revised by Klein 74

40 Poulenc, Oboe Sonata, Mvt. III, “transition” material and "c" at reh. 6

$41 \quad$ Poulenc, Oboe Sonata, Mvt. III, reh. 1

42 Poulenc, Oboe Sonata, Mvt. III, reh. 2 


\section{Introduction}

Francis Poulenc's oboe sonata was his last work. In it, he took the traditional sonata and combined the experimental, populist, and modern styles as a unified form, laying a progressive runway for the further development and maturity of the neoclassical style. From its premier after Poulenc's death in 1963, this sonata has come to represent the epitome of neoclassic chamber music. Reviewing the literature of the oboe sonata, however, reveals that in-depth investigations of this sonata are few and do not attempt to explain the numerous extramusical influences found within it. Such influences from the group known as Les Six-having consisted of Poulenc himself, Louis Durey, Georges Auric, Arthur Honegger, Darius Milhaud, and the only woman of the group Germaine Tailleferre-are neglected. Les Six represented the future of French music innovation between 1917 and 1921, so the absence of literature investigating their personal and musical influences on Poulenc's oboe sonata is unusual. Additionally, further exploration into the oboe sonata uncovers a dedication to Sergei Prokofiev that is seldom discussed; instead, he is usually mentioned in passing as Poulenc's Bridge partner. This all warrants more study into the vital influences of Poulenc's growth, through the depressing moments of his adolescence to his maturity as a confident composer.

The first chapter of this research document reviews biographical information that contextualizes Poulenc's early life, musical influences, and relationships as seen through the lens of Poulenc scholars: Keith Daniel, Roger Nichols, Wilfrid Mellers, Carl Schmidt, and even Poulenc himself in his interviews with Stéphane Audel. He had a special affinity for creating connections - he became a member of the famed Les Six by the grace of Erik Satie, Ricardo Viñes, and famed poet and playwright Jean Cocteau. This alliance developed during formative 
years for Poulenc, as he had no formal compositional education himself. His early musical language was unique and without tampering from the Conservatoire de Paris.

In the second chapter, biographical accounts of the members of Les Six are examined to better understand their own influences and styles, and how these may relate back to Poulenc and the oboe sonata. A list of their oboe works assists the reader with the context of Poulenc's oboe sonata and its placement in time with that of the other oboe works by Les Six.

The final two chapters are concerned with Poulenc's late wind sonatas, oboe sonata, and the neoclassical implications that stem from these compositions. The investigation of Poulenc's late wind sonatas uncovers startling discoveries of Prokofiev's heavy melodic and stylistic influences on Poulenc's works. A comparative analysis of the oboe sonata is performed using research compiled by Poulenc scholar Keith Daniel, theorist Pamela Poulin, and feminist scholar and oboist Margaret Grant that reflect Poulenc's expert settings of the oboe: "oboe as voice," "oboe as virtuoso," and "oboe as tonality." Musical influences of Les Six and Sergei Prokofiev aid the exploration in Poulenc's unusual settings of formal structures and abandonment thereof, as well as neoclassical traits and extramusical ideas. A survey of two trios by Poulenc and Jean Françaix by oboist Siobhán Ciulla suggests that Poulenc's influence on the neoclassical style is mirrored in works of other influential composers in the later half of the twentieth century, well after he died. This raises questions that encourage performers to explore a possible "Poulencien" influence on newly-composed works based on traditional models like the sonata or trio. Finally, a conclusion on the results of the biographical reviews, comparative analysis, and research is given. 


\section{Chapter 1}

\section{The Early Years}

Poulenc was born into a prestigious household. His father, Émile Poulenc, was a successful pharmaceutical manufacturer while his mother, Jenny Zoé Royer, was an excellent amatuer pianist and cultured urban socialite. ${ }^{1}$ Poulenc recalled his early childhood:

I was born in Paris... in the very heart of Paris, a few yards away from the Church of Madeleine, on the 7th of January, 1899. My father came originally from Averyon. He was, together with my two uncles, at the head of a very old chemical products firm which eventually became Rhône-Poulenc. My mother, of purely Parisian descent... came from a line of cabinet makers, bronze workers and tapestry weavers. ${ }^{2}$

Poulenc remembered both of his parents very fondly, but it was his mother Jenny who was the primary source of artistic inspiration to him. She started him on the piano-in which she was expertly trained by the teacher Madam Riss-Arbeau, one of Liszt's last piano students ${ }^{3}$ —and introduced him to poetry and paintings, as well as literature, drama, ballet, and cinema. ${ }^{4}$ Later on in life, he honored her memory by making her the first dedicatee to his only major full-size opera, Dialogues des Carmelites. ${ }^{5}$ Jenny's side of the family was also involved in his musical and educational upbringing, more so than Émile's. Poulenc's uncle Marcel Royer was his Godfather. Young Poulenc and Marcel had a special relationship commonly found between uncles and nephews. Poulenc called him "Papoum" — a name he acquired because of Poulenc's

\footnotetext{
${ }^{1}$ Keith W. Daniel, "Francis Poulenc: A Study Of His Artistic Development And His Musical Style" (PhD diss., State University Of New York At Buffalo, 1980), 2, ProQuest Dissertations \& Theses Global.

${ }^{2}$ Francis Poulenc and Stéphane Audel, My Friends And Myself: Conversations [With] Francis Poulenc, trans. James Harding (London: Dobson Books Ltd., 1978), 29.

${ }^{3}$ Ibid., 30.

${ }^{4}$ Daniel, 2.

${ }^{5}$ Roger Nichols. Poulenc: A Biography (New Haven: Yale University Press, 2020), 2.
} 
inability to pronounce Parrain (godfather). Papoum regularly visited Jenny and the family to discuss the day-to-day happenings of Parisian highlife. Papoum was an avid arts patron, and he would talk about plays, concerts, and artwork that he had recently seen with Jenny while Poulenc played with his toys under the table. ${ }^{6}$ Sometimes Papoum also brought company, and that is when Poulenc met the Opéra-Comique's principal tenor, Edmont Clément; there were several moments in his childhood that helped to shape his musical perspective and tastes, and this was one of them. Poulenc developed a deep appreciation for the human voice after listening to Clément: "I was fascinated, and until the age of fifteen I dreamed of becoming a singer. In the end I had to be satisfied with what I've become, because when my voice broke I was left with the composer's typical sorry squawk."”

Poulenc's father's side and religious beliefs were opposed to the Royers'. His father was a Roman-Catholic, but not dogmatic. Instead, he was a free thinker that believed in Deism—-the belief in a supreme being that does not interfere with the universe. ${ }^{8}$ Their differences continued in that Émile's primary vocation was in pharmaceutical manufacturing, while Jenny was agnostic and trained in the arts. Émile was born in 1855 in Espalion in the south of France close to Averyon. He had two brothers, Camille and Gaston, and in 1900, the three brothers took over the family business and renamed it to the Poulenc-Frères (Poulenc-Brothers). Nichols mentions that each brother took a particular role in the company: Camille in research and Émile in photography, however, Gaston's role is not mentioned. The business venture was successful, bringing in a comfortable income for the family, so much so that Émile was able to hold his own photography studio for sixteen years (1887-1903) at 19 rue du Quatre-Septembre. ${ }^{9}$ The brothers'

\footnotetext{
${ }^{6}$ Poulenc and Audel, 30.

${ }^{7}$ Ibid., 33.

${ }^{8}$ Daniel, 1.

${ }^{9}$ Nichols, 3.
} 
company still exists today, albeit now completely absorbed by other companies. In 1928 , it became Rhône-Poulenc; in 1999, it merged with the German pharmaceutical company Hoechst AG to become Aventis; in 2004, Aventis merged with the French pharmaceutical company Sanofi-Synthélabo to become Sanofi-Aventis. Now the company simply goes by Sanofi, a multinational pharmaceutical company stationed in Paris. Despite parental differences, music was deeply appreciated by everyone in the family, and Émile, while having never been able to play an instrument, rarely missed a rehearsal, concert, or opera he could attend. ${ }^{10}$ Émile's taste for music varied greatly in that he preferred composers like Gounod, Bizet, Delibes, Lalo, Offenbach, Messager, Wagner, and Debussy, but Beethoven may have been his favorite. ${ }^{11}$ Jenny, on the other hand, idolized the music of Mozart, Schubert, Scarlatti, and Chopin. ${ }^{12}$ There is no doubt that Poulenc inherited some of these tastes, taking a particular liking to Mozart early on.

Poulenc wasn't the only child of his family, he had an older sister named Élise Marguerite (b. 1886). Poulenc's sister was already thirteen years old by the time Poulenc came along, and she was raised as a trained singer. Poulenc said that by listening to her sing that she unknowingly contributed to his early education, and "by the time I was fifteen I knew the songs of Fauré, Debussy, and Schumann intimately."13

The family would have been much larger had it not been impacted by tragedy. Jenny had already lost two infants by 1892: Louis Étienne in 1891, and an unnamed stillborn the following year. ${ }^{14}$ So when Poulenc was born in 1889 , he was extremely coddled in the sense that his health was constantly monitored. A quick glance at infant mortality rates in France at the turn of the

\footnotetext{
${ }^{10}$ Poulenc and Audel, 29.

${ }^{11}$ Ibid., 30.

${ }^{12}$ Ibid.

${ }^{13}$ Samuel M. Trickey, "Les Six" (PhD diss., University of North Texas, 1955), 11, ProQuest Dissertations and Theses Global.

${ }^{14}$ Nichols, 4.
} 
century indicates that a quarter of all children died by their sixth birthday. ${ }^{15}$ Poulenc said that his family hired a nanny, Françoise Lauxière (known as "Nounou"), to look after him. She was with the family until he was fifteen. Nichols wonders whether being under constant observation for over a decade during his childhood could have been a major contributing factor to his adult hypochondria. ${ }^{16}$ Outside of Nichols' observation, however, his childhood was actually very stable. His family could afford most of the amenities of the upper middle class, and Poulenc even joked that "[he] grew up in a family for whom gastronomy was a rite; [he] inherited a taste for good food and a wide range of recipes. It [was his] culinary ancestry." ${ }^{17}$

As mentioned before, Jenny started Poulenc on the piano as early as five years old. Later on, she passed him to an assistant that he did not remember the name of. Instead, "she impressed me more with her vast bespangled hats and gray dresses than her mediocre teaching." ${ }^{18}$ But in 1907, Poulenc recalled being taught by a new teacher, Mlle Melon, the private coach to César Frank's niece, who he remarked had very good technical principles. ${ }^{19}$ She inspired him so much that when he found "a free few minutes during the day, [he'd] run to the piano and sight-read." ${ }^{20}$ Poulenc's education seemed to be a point of contention at home, however. When Audel asked Poulenc why he hadn't entered the Conservatoire when he was younger, Poulenc responded that there was a parental disagreement as to what he should do with his future. ${ }^{21}$ Poulenc's father insisted that he receive a "traditional" education, whereas Jenny felt the opposite and he should

\footnotetext{
${ }^{15}$ Guillaume Blacc and Romain Wacziarg, Explorations in Economic History, vol. 78, Change and Persistence in the Age of Modernization: Saint-Germain-d'Anxure, 1730-1895 (Amsterdam: Elsevier, 2020), 2.

${ }^{16}$ Nichols, 4.

${ }^{17}$ Ibid., 5.

${ }^{18}$ Poulenc and Audel, 34.

${ }^{19}$ Ibid.

${ }^{20}$ Ibid.

${ }^{21}$ Ibid.
} 
go to the Conservatoire - all of this coinciding with the onset of World War I. As he said in his interviews:

My mother, who felt immediately that music was my only vocation, would certainly have let me enter the Conservatoire. Artists had always been accepted in her family, and it seemed to her quite natural. But my father, despite his love for music, was unable to agree that an industrialist's son shouldn't sit for his two school-leaving exams. "He can do what he likes afterwards," my father used to repeat. The result was that, continually sacrificing my conventional education to my beloved piano, I was a less than indifferent pupil at school. ${ }^{22}$

Poulenc was homeschooled until he was around thirteen years old by the same governess that taught his mother and sister, but then later attended the Petit Condorcet - a feeder school to the Lycée Condorcet, which, founded in 1803, is still one of the oldest and most prestigious Parisian high schools. After starting his second year, Poulenc was sent home in 1914 for being "sick." Nichols believes this was due to one of his first depressive episodes, a problem that returned for the rest of his life. ${ }^{23}$ To make matters worse, in 1915, his mother Jenny passed away. Nichols mentions that Poulenc was quiet in dealing with the death of his mother, but it was something he most deeply felt-he was just sixteen years old, struggling with completing school, dealing with early mental health issues, and being forced into an education he did not want. Instead, he internalized his trauma, which no doubt fed his already problematic mental state. ${ }^{24} \mathrm{He}$ returned to school early in 1916 and passed the first part of the baccalauréat in an unusual manner. Poulenc's scores in geography $(5 / 20)$ and physics $(6 / 20)$ were very poor, but an essay on Diderot, the French philosopher and co-founder of the Encyclopédie, was stellar $(36 / 40) .{ }^{25} \mathrm{He}$ was accused of being a cheater or a somehow remarkable student. ${ }^{26}$ For his oral exam, he was

\footnotetext{
${ }^{22}$ Poulenc and Audel, 35.

${ }^{23}$ Nichols, 9 .

${ }^{24}$ Ibid., 12.

${ }^{25}$ Ibid., 13.

${ }^{26}$ Ibid., 14.
} 
asked to discuss any topic, so he chose the 18th century writer and political philosopher, Montesquieu. He passed, and his father gave him a promised camera. ${ }^{27}$ Unfortunately, when he returned to school in the fall, he fell back into mental health crises and was unable to finish at that time.

In 1917, tragedy struck again with the death of his father, Émile. Poulenc (now eighteen) had dealt with the death of both of his parents, ongoing problems at school, and, now orphaned, he moved in with his older sister Élise and her family. Thankfully, Poulenc was able to finish his exams in 1918, but quickly entered the army for a brief three-year service. ${ }^{28}$ While in the military, he was frequently punished with days in solitary for overstaying his leave, citing that he was bored and, writing to his sister, if he "only had someone to talk to, but here I have nothing but imbeciles as companions.. ${ }^{29} \mathrm{He}$ attempted to become a Red Cross driver, but nothing ever came of it. Instead, he ended up taking an office post in Paris before being delisted in $1921 .^{30}$

It is important to mention the musical influences of Poulenc's tender years. Obviously, Jenny and Émile imparted their tastes for certain composers onto Poulenc. He had a strong inclination toward one composer, however, and it is someone not often associated with Poulenc. Around 1910, the Seine River overflowed, and most of central Paris (and the Poulenc family home) had flooded, so the Poulencs fled to the Fontainebleau Forest to the South. Both Daniel and Nichols agree that for the eleven-year-old Poulenc, this event sparked a musical turning point for him. Poulenc discovered the score to Die Winterreise by Schubert at a local music shop and he was awestruck-“I went from magic moment to magic moment. By a bizarre coincidence, city-raised as I had been, I discovered all at once the beauty of the country, the

\footnotetext{
${ }^{27}$ Nichols, 14.

${ }^{28}$ Poulenc and Audel, 35.

${ }^{29}$ Nichols, 22.

${ }^{30}$ Ibid.
} 
winter, and its sublime musical transmutation... Something very profound was changed in my life." ${ }^{31}$ Nichols offers another visual account of this moment through the lens of musicologist Hervé Lacombe:

By turning his piano round, he can, at about $4 \mathrm{pm}$, see the sun moving through the forest trees covered with frost. The song he is then singing harmonizes with the countryside. This fusion of the visual, the musical and the poetic is the open sesame of his future aesthetic, in the same way that the expressive restraint and the accuracy of declamation, the balance and interplay between piano and voice are a lesson for his future as a song composer. $^{32}$

Daniel suggests that even though Schubert was not the most direct influence on his compositional style, this event imparted a "mood and spirit" in the setting of his lyrical melodies between voice and piano and their shifting between major and minor. ${ }^{33}$ These early influences contributed to the twin nature of Poulenc's later bourgeoisie style, also described as "street music" by himself, in that "its genuineness has been suspected, and yet there's nothing more genuine in me. Our two families ran their business houses in the Marais district, full of lovely old houses, a few yards from the Bastille. From childhood onwards I've associated café tunes with the Couperin Suites in a common love without distinguishing between them. ${ }^{34}$ Also at eleven, Poulenc was introduced to the music of Stravinsky when he attended a concert featuring the "Berceuse" from L'Oiseau de feu ${ }^{35}$ Poulenc also heard the notorious Le Sacre du printemps at the famous Théâtre des Champs-Elysées just three years later. ${ }^{36}$ Nichols and Poulin disagree if he

\footnotetext{
${ }^{31}$ Daniel, 4.

${ }^{32}$ Nichols, 6.

${ }^{33}$ Daniel, 4.

${ }^{34}$ Poulenc and Audel, 31.

${ }^{35}$ Pamela L. Poulin, "Three Stylistic Traits in Poulenc's Chamber Works For Wind Instruments" (PhD diss., University of Rochester, Eastman School of Music, 1983), 4, ProQuest Dissertations and Theses Global.

${ }^{36}$ Ibid.
} 
was at the infamous premiere that sent shockwaves through Paris but they do agree that it awed him:

I came home so shocked and thunderstruck that, during the evening, I couldn't conceal from my parents how I'd spent the day. "It's not a concert for someone your age," said my father, as if the memorable scandal had been caused by some indecency or other. My mother smiled, approving internally, and said nothing. "You really have got some weird taste, my poor boy!” [M]y father finally grumbled! "Ah well!!!” His “Ah wells” were a sign of resignation, and the incident was closed. ${ }^{37}$

Another composer Poulenc mentioned often was Debussy, having first heard him in 1907 when he was eight. A harpist friend of the family performed Danses sacrée et profane with string orchestra, and Poulenc remarked, "It's so pretty! It's a bit out of tune!" 38 He was so excited that he wanted to play the piece, and subsequently got copies of La Soirée dans Grenade and Jardins sous la pluie to try out, although they were well above his capabilities. Poulenc recalled a moment in which he met Debussy in passing:

I'd often seen Debussy at the Concerts Colonne rehearsals, on Saturday mornings at the Châtelet, which he came to with his daughter Chouchou. My dream was to meet him. Well, one day I saw Debussy and his wife going into a shop that sold mourning clothes (such shops existed before 1914). While Mme Debussy and my mother were trying things on in adjoining rooms, I took advantage of a moment when Debussy was telephoning to touch the lining of his hat, which he'd left on a chair. If I'd dared, I'd have kissed it. Debussy returned a moment later, I was blushing with pleasure, shame and timidity. I think he saw this, because he gave me a little smile when he saw me gazing at him with such admiration. ${ }^{39}$

Sadly, Poulenc never got to meet Debussy formally since he soon passed away from cancer as Poulenc's career was "auspiciously beginning." ${ }^{40}$ For Poulenc, Debussy continued to be a source of inspiration for him, especially in works later on like the flute sonata. Poulenc

\footnotetext{
${ }^{37}$ Nichols, 10.

${ }^{38}$ Ibid., 5.

${ }^{39}$ Ibid.

${ }^{40}$ Daniel, 6.
} 
confirmed his influences with Audel after being jokingly asked if he were to be exiled to a desert island, what five composers he would take with him. Poulenc replied, "Mozart above all else, then Schubert, Chopin, Debussy, and Stravinsky."${ }^{\not 11}$

\section{Tutelage: Viñes, Satie, and Others}

In 1914, Poulenc met Ricardo Viñes, the celebrated virtuoso pianist, through a mutual family friend, Mme Sienkiewicz. Poulenc was enamoured with him - he had given some of the very first piano performances of Debussy, Ravel, Falla, Satie, Prokofiev, and Albeniz's contemporary piano works in Paris. ${ }^{42}$ He began taking piano lessons with Viñes, and Poulenc said this was another turning point in his life; he felt as though he owed Viñes everything. His first flights in music, and everything he really knew about the piano, were taught to him by Viñes. ${ }^{43}$ Poulenc described him as

a delightful man, a bizarre hidalgo with enormous mustachios, a flat-brimmed sombrero in the purest Spanish style, and button boots with which he used to wrap my shins when I didn't change the pedal enough. Viñes was paramount in the way he handled pedaling, that essential factor in modern music. He succeeded in playing crisply even through a wash of pedal! And what cunning he showed in distinguishing between staccato and full legato! ${ }^{44}$

His first sessions started out as a half hour lesson each week, but these lasted hours until Poulenc joked that he had spent his entire life with him. ${ }^{45}$ They discussed poetry and paintings, as well as arranged meetings with other pupils and prominent figures like Satie, Cocteau, Auric, and Stravinsky. ${ }^{46}$ There must have been no shortage of topics to talk about, especially with the

\footnotetext{
${ }^{41}$ Poulenc and Audel, 59.

${ }^{42}$ Nichols, 11.

${ }^{43}$ Poulenc and Audel, 36.

${ }^{44}$ Ibid., 37.

${ }^{45}$ Daniel, 21.

${ }^{46}$ Ibid., 22.
} 
arts experiencing massive advancements in every discipline. Daniel confirms that at this point of time that Paris was

particularly vibrant during the first fifteen years of the twentieth century: Debussy, Ravel, Stravinsky, and Satie in music; Valery, Cendrars, and Apollinaire in poetry; Jarry and Claudel in theater; Rolland, Gide, and Proust in literature; Fauvism (Derain, Dufy, Vlaminck) and Cubism (Braque and Picasso) in art; and the coalescence of the arts in Diaghilev's Ballets russes. The harsh realities of war brought about significant changes in this artistic scene. Such great men as Debussy, Peguy, Apollinaire, and Alain-Fournier died during the war years, while numerous cultural institutions either closed, or were forced to operate with reduced budgets and audiences. ${ }^{47}$

Nichols and Poulenc both mention how Viñes was not respected by many of his contemporaries, as he was not a "Romantic" virtuoso and his right to be so-called was questioned. ${ }^{48}$ From his recordings he was remarked to have a "sparkling, colorful tone and elegant phrasing that made him a successful pianist." ${ }^{49}$ Viñes encouraged Poulenc to start composing more seriously, and even premiered all of Poulenc's early piano works. ${ }^{50}$ One of these works, and the oldest of his published pieces, Pastorale, is dedicated to him. Viñes was paramount in Poulenc's navigation of the Parisian intellectual community. Since Poulenc never attended the Conservatoire, his connections were limited. Viñes was the person who introduced him to Satie, Auric (the future member of Les Six), and to many others. In 1917, when Poulenc, with no formal training, was shopping around for a new composition teacher, Viñes assisted him dutifully. He was turned away quite frequently, the first by Paul Dukas, who was no longer accepting students. Poulenc had some other humorously awkward and terrible meetings with teachers that he wrote to Viñes about. At Dukas's suggestion, one of these was with Paul Vidal, and it could not have gone more wrong:

\footnotetext{
${ }^{47}$ Daniel, 23-24.

${ }^{48}$ Nichols, 37.

${ }^{49}$ Ibid.

${ }^{50}$ Ibid., 38.
} 
He asked if I'd brought him a manuscript. I handed him the manuscript of my Rapsodie négre. He read it closely, wrinkled his brow and, on seeing dedication to Erik Satie, rolled his eyes in a rage, got up and yelled these precise words: "Your work's disgusting, inept, a load of tasteless garbage. You're trying to make a fool of me with the consecutive fifths everywhere. And what the Hell is this 'Honoloulou?' Ah! I see you're a member of the gang of Stravinsky, Satie \& Co. Well good-day to you!"51

Disheartened, Poulenc returned to Viñes who tried to help him find a teacher again, this time with Ravel. Again, things did not go to plan as Ravel dismantled all of Poulenc's tastes right in front of him, leaving him feeling extremely uncomfortable. Poulenc recalled Ravel's words from this meeting:

Schumann...pooh! pooh! pooh! ... was a nonentity ... that Mendelssohn.... was wonderful.... That Mendelssohn's Songs without Words were a thousand times better than Schumann's Carnaval, that all the later works by Debussy... which [Poulenc] worshipped - which, in fact, I was one of the very few to worship - that is Jeux and the Etudes pour piano... were none of them “good” Debussy. That Debussy's musical old age wasn't up to much; that Saint-Saëns was a musician genius... that Chabrier wasn't equal to orchestrating his own music, and so on. All this bowled me over. I came out [of that meeting] as though I'd been K.O.'d. ${ }^{52}$

Eventually, he managed to find a teacher after four years of trying. At the direction of Milhaud, Poulenc wrote to Charles Koechlin asking to take lessons. Koechlin was considered to be the best counterpoint instructor in France at the time. Poulenc studied with him for forty-eight lessons between 1921 and 1925, and during them, Koechlin adapted his teaching style to fit Poulenc's needs - he felt that Poulenc was more of a harmonist than a contrapuntist. ${ }^{53}$ So he trained him in four-part harmony by doing realizations of Bach chorales, as well as typical counterpoint exercises. ${ }^{54}$ Poulenc felt that this had a strong effect on him and he credited Koechlin with his appetite for choral music. ${ }^{55}$ He also said that he deeply influenced some of the

\footnotetext{
${ }^{51}$ Nichols, 14.

${ }^{52}$ Poulenc and Audel, 126.

${ }^{53}$ Ibid., 35.

${ }^{54}$ Ibid.

${ }^{55}$ Ibid.
} 
compositional directions he took at different times in his career. ${ }^{56}$ Poulenc's later religious works and choral-like undertones in instrumental works can possibly be traced back to his time spent with Koechlin.

Probably the most notable friendship Poulenc made was with Satie in 1917. Satie's Parade had just premiered at the Ballets Russes, and it sent another culture shock through Paris not felt since Le Sacre du printemps. Poulenc was at that opening concert and he said, "I was conquered! With all the injustice of youth, and although I idolized Debussy, I agreed to disown him a little because I was so eager for the new inspiration Satie and Picasso were bringing us. That was the time Viñes introduced me to Satie."${ }^{, 57}$

Parade had come to symbolize a new direction in the arts, involving all facets of intellectualism and collaboration in the arts community. Diagheliv commissioned the piece for the Ballets Russes, Picasso designed the cubist set and costumes, Cocteau wrote the scene, and Satie provided the score. Program notes were written by the poet Apollinaire, and in them he coined this new direction as surréalisme - the surrealist movement. This "New Spirit" came out of what was thought to be the end of Impressionism and Wagnerian symbolism, and that the experimental techniques used in Parade embodied it: "Satie created a deliberately banal score employing real sound effects (one of the first examples of musique concréte) and a bit of American jazz (one of the first instances of its use by a European composer). ${ }^{958}$ Poulenc, like so many others, was enamored, and as Daniel rightly puts it, "for the first time, a French composer had thrown off the multiple influences of Wagner, Romanticism, Impressionism, and Russian exoticism." 59

\footnotetext{
${ }^{56}$ Poulenc and Audel, 38.

${ }^{57}$ Ibid., 39.

${ }^{58}$ Daniel, 25.

${ }^{59}$ Ibid., 26.
} 
Poulenc's first meeting with Satie actually happened before Parade premiered. Like so many of his other tragic meetings with composers, Satie was not initially impressed with him. Instead, Satie was rather "suspicious" of him because he came from a middle-class family. ${ }^{60} \mathrm{He}$ seemed to change his mind, however, after Poulenc attended the premiere and subsequently congratulated and celebrated his great success. On another occasion, Satie, who was on board with Poulenc now (and never one for a lack of humor), caught wind from Auric about Poulenc's disastrous meeting with Vidal. He offered him some consolation:

Cher Ami, I'd like to see you. You seem lost to me but easy to find again. Suggest a date. Who can be giving you such strange advice? It's funny. Never mix your schools: the result is an explosion, which after all is quite natural. What's more, if I'm to give you useful advice, I shall have to know what you plan to do and what you can do. Your application to Vidal was that of an amateur pupil, not an artist pupil. He showed you that himself. He's an old dyed-in-the-wood prima donna who's put you off your stroke. Laugh it off, old chap. Yours ever, Erik Satie ${ }^{61}$

Poulenc recalled that this letter cemented their friendship. Daniel and Poulin mention that around 1917 is when Poulenc began to show Satie's experimental influences in his own compositions. Satie's influence was felt so widely at the time that even Debussy consulted him, playing a key part in the creation of Pelléas et Mélisande. ${ }^{62}$

Unfortunately for Satie and Poulenc (and Auric), there was a massive falling out in 1924. Satie, who was known to be extremely volatile, had cut them both off completely because they had become friendly with music critic Louis Laloy, Satie's dubbed "arch-enemy." ${ }^{\prime 3}$ Poulenc exacerbated the issue when he attended Satie's ballet Mercure later that year. He, with some others, created an artists' manifesto called "Hommage á Picasso" thanking Picasso for being the

\footnotetext{
${ }^{60}$ Poulenc and Audel, 39.

${ }^{61}$ Ibid., 40.

${ }^{62}$ Ibid., 65.

${ }^{63}$ Daniel, 28.
} 
leader of young surrealists with absolutely no mention of Satie or his contributions. This made Satie livid to the point where there was no chance of forgiveness. ${ }^{64}$ Poulenc regretted this decision later on and distanced himself from the other artists he wrote the manifesto with, but the damage was done. Daniel mentions that Poulenc visited Satie on his deathbed in 1925, and it was Milhaud and Poulenc who were given the task of putting together Satie's belongings from his room. ${ }^{65}$ While it's not known what was said between them, it does seem as though they mended things to some degree since he allowed Poulenc to help gather his things from his studio after he passed.

When Audel asked him to paint a portrait of Satie when he was alive, Poulenc remembered him both humorously and fondly:

Winter and summer alike, Satie never left off the bowler hat which he respected, nor the umbrella he adored. At his death, when people could at last get into his room at Arcueil where, during his lifetime, no one had ever dared venture, a hundred or so umbrellas were discovered...some of them weren't even taken out of the shop-paper they were wrapped in... Satie's overcoat, rarely left off even in summer, wrapped him round like a dressing-gown. He had a goatee-beard which he carefully trimmed over and over again, and a pair of pince-nez which he was always re-adjusting with an imperious hand. Such were the characteristics of that odd half-French, half-Irish personality. ${ }^{66}$

And regarding his ability to play piano:

Satie played the piano very badly, especially towards the end of his life. He was very fond of the piano for sure, but most of his pieces were written on café tables at Arcueil Cachan. Anyway, the piano to be found in Satie's home after his death was completely unplayable, and Braque bought it as a relic, nothing more. ${ }^{67}$

Satie was larger than life, or at least his presence demanded that attention. It's easy to see how he drew so many in - he was extremely talented, a visual spectacle, and had an attractive yet

\footnotetext{
${ }^{64}$ Daniel, 28.

${ }^{65}$ Ibid., 29.

${ }^{66}$ Poulenc and Audel, 66.

${ }^{67}$ Ibid., 70.
} 
abusive personality. What people admire about his music is its "simplicity and its tunefulness, characterized by its inclusion of jazz and music-hall influences." 68

\section{Growing Popularity}

The years between 1917 and 1921 were a busy period of time for Poulenc. While finishing high school at the Lycée Condorcet, adjusting to the new living situation at his sister's house, networking, and then deployment, Poulenc somehow composed his first public works: Rapsodie négre (1917), Trois Pastorales (1918), Toréador (1918), Jongleurs (1918, destroyed/never performed), Sonata for Two Clarinets (1918), Sonata for Piano 4 Hands (1918), Mouvements perpétuels (1918), Le Bestiaire (1919), Cocardes (1919), and Valse (1919). The first of these works to be performed was the already controversial Rapsodie négre that got him ejected from Vidal's studio. It was performed at a Les Nouveaux Jeunes concert on December 17th, 1917, along with works by Auric, Honegger, Durey, Tailleferre, and Alexis

Roland-Manuel. These composers, while missing Milhaud (and with the exception of Roland-Manuel), would become the famed members of Les Six. Poulenc had already been making a name for himself thanks to the championship of Viñes. Viñes had been performing his piece, Mouvements perpétuels, at every concert of his from 1919 and $1920 .{ }^{69}$ Poulenc's attachment to that piece and Viñes was painfully sincere. After World War II in Barcelona, Poulenc performed Mouvements perpétuels as “an encore in Viñes’s memory... bursting into tears" ${ }^{\prime 70}$ on stage. Poulenc's attachment to emotional memory and flattery wasn't anything short either, it was something that he consciously practiced early on. He got his foot in the door with

\footnotetext{
${ }^{68}$ Daniel, 26.

${ }^{69}$ Ibid., 22.

${ }^{70}$ Nichols, 31 .
} 
Satie by dedicating the infamous Rapsodie négre to him, a move that greatly impressed the mercurial composer.

The group, Les Nouveaux Jeunes, was named by Satie as he acted as their adopted "unofficial guardian." Honegger in André Gédalge's composition class at the Conservatoire and they became very good friends. While Milhaud was in Brazil in 1917 working as a foreign affairs secretary, Honegger was introduced to Auric and Durey by Satie. ${ }^{72}$ The three of them formed the core of the group, adding Poulenc and Tailleferre later that year, and finally including Milhaud when he returned from Brazil. Daniel mentions that this is where Cocteau's association with the group began, having been instrumental in its assembly. Concerts featuring Les Nouveaux Jeunes were presented between 1917 and 1920 at the Salle Huyghens, a studio owned by painter Émile Lejeune for use by artists as a theatre or hall. ${ }^{73}$ These concerts were very popular, attracting attention and involvement from the larger Parisian art community with the likes of Picasso, Georges Braque, Juan Gris, and Amedeo Modigliani. ${ }^{74}$ Three of Poulenc's works were considered favorites and regularly performed there: Mouvements perpétuels, Cocardes, and Le Bestiaire ${ }^{75}$ Cocteau recounted those performances and the hall:

I detest sentimentalizing over meager souvenirs, but the Salle Huyghens was not without its charm. We listened to music and poetry standing - not as a matter of respect, but owing to a lack of chairs. The stove used to burn well in the spring but in winter it refused to draw. Beautiful ladies in furs could be seen next to "djibbahs" of Montmartre and Montparnasse. These miracles did not last long, but while poets and painters were

\footnotetext{
${ }^{71}$ Daniel, 29.

72 Ibid., 30.

${ }^{73}$ Carl B. Schmidt, Entrancing Muse: A Documented Biography of Francis Poulenc (Hillsdale: Pendragon Press, 2001), 455.

${ }^{74}$ Daniel, 30.

${ }^{75}$ Ibid., 31.
} 
learning to hate each other, our musicians came together, supported one another, and formed under the title "Nouveaux Jeunes." 76

At one of these concerts featuring Rapsodie négre, the singer refused to perform, so Poulenc, still in military uniform, got on stage and sang "Honoloulou." ${ }^{.77}$ Rapsodie négre used pseudo-African poetry, crunchy dissonances, parallel fifths and octaves, and very simple text that Daniel said "riled the audience and caused the succés de scandale that every young composer dreams of." ${ }^{, 78}$ After another performance of the piece, Poulenc was crowned "enfant terrible" and his association with Satie, Cocteau, and Les Nouveaux Jeunes was formalized. ${ }^{79}$ Cocteau continued to engage in work with Poulenc and Auric, feeling that they were the most Parisian of the New Youth and therefore, the most representative of the new style. Cocteau further suggested that they "abandon the philosophical mists and wanderings of German Romanticism and French Impressionism in favor of light, tuneful, popular French art, based on the music of the circus, café-concert, and the music-hall." ${ }^{80} \mathrm{He}$ preferred music that was based on instinct instead of intellect, and that "instinct must be controlled by method, but only instinct helps us discover a method which is our own, and through which we can control our instinct." ${ }^{181}$

Poulenc's early works can be described in this manner: they are more tuneful and less of a wash of "clouds, waves, aquariums, undines, and perfumes of the night" associated with the likes of Debussy and Ravel. ${ }^{82}$ More specifically, Poulin lists them as being more "influenced by Stravinksy ... characterized by the non-tonal use of exact sequences, exotic scales, chords in oscillation, ostinati and parallelism, as well as polymeters, isomelody and the manipulation of

\footnotetext{
${ }^{76}$ Daniel, 31.

${ }^{77}$ Ibid., 33.

${ }^{78}$ Ibid.

${ }^{79}$ Ibid.

${ }^{80}$ Ibid., 35.

${ }^{81}$ Ibid.

${ }^{82}$ Ibid., 34.
} 
pitch within cells.. ${ }^{83}$ Cocardes and Toréador, vocal examples, further suggest a move toward clarity as they are set to syllabic text, avoiding muddy melismas. This seems to be a favored formula for Poulenc that he revisits later on. Similarities in his other early works exist: short tunes, explosive crunchy chords, repetitive ostinati, clear text, frequent use of grace notes for rhythmic inflection, and spread dissonant chords at the end of pieces. These techniques resemble his early street music style and offer the first glimpse into his developing twin natures.

It wasn't until late 1919 that members of Les Nouveaux Jeunes began to be featured more exclusively on concert programs. Word of their concerts spread and the music critic Henri Collet caught wind of them. In his first review "La Musique chez soi; Les Cinq Russes, Les Six Français et Erik Satie" in the art paper Comœedia, he compared them to the great Russian Five, and a week later in another article dubbed them Les Six Français. ${ }^{84}$ This name was officially shortened to Les Six by January 16th, 1920, thereby glueing these six composers together in music history forever.

\footnotetext{
${ }^{83}$ Poulin, v-vi.

${ }^{84}$ Daniel, 40-41.
} 


\section{Chapter 2}

\section{Les Six and First Collaborations}

As early as 1917, Satie, Viñes, and Cocteau were instrumental in introducing Auric, Poulenc, Milhaud, Honegger, Durey, and Tailleferre to one another and provided them with performance opportunities. It was because of these events that Collet named them Les Six citing their "unique association of personalities" 85 and how frequently their works appeared at concerts together. Despite the ubiquitous name, Poulenc said they couldn't have been more different: "we had never had any common aesthetic and our musical styles have always been dissimilar. Our likes and dislikes opposed. Thus, Honegger has never liked Satie's music, and [Florent] Schmitt, whom he then admired, was a pet aversion for Milhaud and me." 86

Trickey confirms this sentiment, saying while they were all "French born, their bonds did not share national and vocational interests." ${ }^{87}$ Sensing the importance of their new label, Milhaud was the most aware of how their group's identity was a "useful asset" in their promotion and collaborations. ${ }^{88}$ He said the group didn't really object to their new name (except for him). Instead, they understood the commercial appeal it brought, while mentioning the difficulty of going solo in Paris: ${ }^{89}$

Collet's article excited such world-wide interest that the "Group of Six" was launched, and willy-nilly I formed part of it.

This being so, we decided to give some "Concerts des Six." The first was devoted to our work; . . . Satie was our mascot. He was very popular among us. . . The purity of

\footnotetext{
${ }^{85}$ Samuel M. Trickey, "Les Six" (PhD diss., University of North Texas, 1955), 1, ProQuest Dissertations and Theses Global.

${ }^{86}$ Poulenc and Audel, 42.

${ }^{87}$ Trickey, 14.

${ }^{88}$ Ibid., 40.

${ }^{89}$ Ibid.
} 
his art, his horror of all concessions, his contempt for money, and his ruthless attitude toward the critics were a marvelous example for us all.

The formation of the Group of Six helped to draw the bonds of friendship closer among us. For two years we met regularly at my place every Saturday evening. ... we would play our latest compositions. Some of them, such as Auric's Adieu New York, Poulenc's Cocardes, and my Boeuf sur le toit were continually being played. We even used to insist on Poulenc playing Cocardes every Saturday evening, as he did most readily. Out of these meetings, in which a spirit of carefree gaiety reigned, many a fruitful collaboration was to be born; they also determined the character of several works strongly marked by the influence of the music hall..$^{90}$

The group's first joint work was a thought-project of Cocteau's—a four volume broadsheet (a folding colored-paper containing all forms of art and even musical snippets) called Le Coq, later renamed Le Coq parisien. ${ }^{91}$ Through this they reached a much larger audience, and after sharing their thoughts and ideas, they subsequently acquired a "bad boy" reputation. The paper's "tone was generally pseudo-serious, self-centered, and somewhat condescending," and meant to offend.${ }^{92}$ In 1920 , they worked on another group project, L'Album des Six. Oddly enough, this was the last work in which all six members were featured together. The next of these large projects by Cocteau, Les Mariés de la tour Eiffel, was a ballet depicting various scenes on the Eiffel Tower, narrated by phonographs. ${ }^{93}$ Durey did not participate and was already trying to leave Les Six to write music for French communist functions, a move that infuriated Cocteau ${ }^{94}$ This was also the last time Honegger worked with the group, too, instead going into a different musical direction for the rest of his career. ${ }^{95}$ Auric, Poulenc, Milhaud, and Tailleferre collaborated on other projects after Les Mariés de la tour Eiffel, but effectively the group was dissolved by 1921. Only three of them could be heard performing jointly at concerts then:

\footnotetext{
${ }^{90}$ Trickey, 40.

${ }^{91}$ Daniel, 41-42.

${ }^{92}$ Ibid., 42.

${ }^{93}$ Ibid., 45.

${ }^{94}$ Ibid., 46.

${ }^{95}$ Ibid.
} 
Milhaud, Auric, and Poulenc. ${ }^{96}$ Daniel mentions that even though "the six composers who comprised this coterie never actually formed a unified whole" they were mainly bound by friendship and that they performed together frequently. ${ }^{97} \mathrm{He}$ goes on to say that they

were a liberating force on French music and on the state of art in general. They were responsible (in France, at least) for the downfall of Wagnerism and Impressionism, and they accelerated the decline of romanticism that had begun in the decade 1910-1920 with the music of Satie and Stravinsky. They helped to lay the artistic foundation of skepticism and banality upon which Dada and Surrealism flourished. They brought music back down to earth - indeed, they traced it back to its popular roots. They helped usher in a decade of pleasure (of hedonism, some might argue) and of musical and aesthetic freedom. They set the stage for, and became some of the chief proponents of, musical neo-classicism. And they contributed to the continuing importance of Paris as a musical and cultural center. $^{98}$

There is no doubt that if Collet had chosen to highlight any other composer at those concerts during the Les Nouveaux Jeunes era, the course of music history may have appeared very different.

\section{Their Different Styles}

In general, three aspects may be discerned in the total state of affairs which existed during the formative years of the lives of Les Six. These may be categorically identified as: [1] a national psychosis engendered by the fear of war, the actual experience of war, and the after effects of war; [2] an acute awareness of a feeling of revulsion toward the end products of the Romantic period; and [3] a realization that the lode of the anti-Romantic impressionist techniques had reached the point of exhaustion making further exploitation profitless.

—Samuel Trickey, Les Six

Trickey's 1955 dissertation, Les Six, provides an in-depth biographical account of its members. Their compositional styles can be characterized as a reaction to many different world

\footnotetext{
${ }^{96}$ Daniel, 45.

${ }^{97}$ Ibid., 46.

${ }^{98}$ Ibid., 47.
} 
events happening simultaneously: World War I, an existential shift away from Romanticism and early 20th century Impressionism, and a turn to more accessible and pedestrian concert styles. Paris was a melting pot of styles with artists from all callings between the period of 1910 and 1920. Their joint collaborations reached a boiling point in 1913 with Stravinsky's Le Sacre du printemps at the Ballets Russes, creating a near-riot through the streets of Paris. And again in 1917, as another such event happened with Satie's Parade, signalling a second monumental shift in the arts. The members of Les Six, as young adults, lived through these historical moments, and there is no doubt that their compositional styles were influenced by them.

In the following section, I will review Trickey's biographical account of the members of Les Six while also noting their compositional influences and styles during the period of time up to and between 1917 and 1921. These elements, in turn, influenced Poulenc's own compositions, namely the oboe sonata.

Trickey describes Milhaud "as [a] Frenchman from Provence, and by religion a Jew." 99 His parents, both musicians, encouraged him to experiment at an early age. ${ }^{100}$ He began playing violin at seven years old and, despite his aversion to it, learned to compose in four-part harmony at thirteen. ${ }^{101}$ When he turned eighteen, he entered the Conservatoire where he studied violin with Berthelier, harmony with Leroux and Pech, and chamber music with Dukas. ${ }^{102}$ His dislike for harmony manifested itself further, and he subsequently dropped out of Leroux's classes, turning to Gédalge and Widor for composition and orchestration. ${ }^{103}$ At some point he decided to end his violin studies to pursue composition completely. This coincided with military service during World War I, choosing to serve as a secretary to the Ministry of Foreign Affairs with a

\footnotetext{
${ }^{99}$ Trickey, 2.

${ }^{100}$ Ibid.

${ }^{101}$ Ibid.

102 Ibid.

${ }^{103}$ Ibid., 3.
} 
one-year stint in Brazil from 1917 to 1918 . He was still a member of Les Nouveaux Jeunes in absentia, and upon his return to Paris immediately joined with the other members under Satie's guidance. He viewed Satie, Couperin, Rameau, Berlioz, Chabrier, Bizet, and Debussy as the "masters to whom France owed its true musical heritage." 104 And he attributed Satie as the new figurehead of the French renaissance. ${ }^{105}$

As far as his compositional style and preferences, he saw diatonicism and chromaticism as fundamentally opposed - a theory that later warped into ideas of "polytonality and atonality."106 Trickey suggests that Milhaud preferred diatonic melodies while exploring polytonality. To Milhaud, he saw that it was melody that "united the group of French musicians to which he wished to be allied."107 Milhaud explained the importance of melody further:

What gives life to a work, what makes it true, will never be its characteristics, polytonal or atonal, but, rather, its essential melody. Thence springs its real power, because it comes straight from the heart of the musician. There is no training so complete or so thorough that it can suffice without that melodic source. It is the primary element, the authentic organic one, that comes from the pure sentiment itself and that is conducive to rhythmic and harmonic design. Without melody, all composing will fall, or end in vain rhetoric, quite conventional and empty. It is the entire secret of music... ${ }^{108}$

Around 1921, Milhaud had shown that he leaned toward certain composers, namely Bach, Mendelssohn, Schubert, Berlioz, Debussy, and Magnard, while “despising” Schumann and Wagner, and disliking Brahms. ${ }^{109}$ He found their works to be too heavily orchestrated, and Wagner's "influence on music and musicians was malign and destructive." ${ }^{110}$ Regarding his fellow Les Six members, he claimed that "apart from our attachment to polytone, we have little in

\footnotetext{
104 Trickey, 45.

105 Ibid., 46.

${ }^{106}$ Ibid.

107 Ibid., 47.

${ }^{108}$ Ibid.

${ }^{109}$ Ibid., 48-49.

${ }^{110}$ Ibid., 49.
} 
common... We are a proclamation and a protest. We proclaim the death of musical Impressionism. We protest against the unnecessary complexities of contemporary instrumentation."111

He added that Honneger dwelt too much in German Romanticism and Tailleferre was too "sympathetic" to Impressionists; Auric and Poulenc were the most Satie-like, but he found Poulenc's compositions more original, describing them with "gaiety, precision, charm, and grace." $" 112$ With Durey he made no comment.

Born in Le Havre, France (the Normandy region) to Swiss parents, Honegger's beginnings were similar to Poulenc. His first piano lessons were given to him by his mother, but his father wanted him to go into the family business. ${ }^{113}$ He studied violin with Émile Sautreuil and harmony with organist Robert-Charles Martin before being forced into the family trade. ${ }^{114}$ Honegger lucked out because his father, observing his lack of skill in the family trade, sent him to the Zurich Conservatory for two years instead. By 1912, he returned to France and entered the Conservatoire, studying composition with Charles Widor and André Gédalge, conducting and orchestration with Vincent d'Indy, and violin with Lucien Capet. ${ }^{115}$ He met Milhaud, Auric, and Tailleferre there and "they sensed a similarity of outlook and began a lasting personal and musical friendship." $" 116$ His time at the Conservatoire was cut short, as he went back to Switzerland in 1914 to complete military service, a requirement for all Swiss citizens. ${ }^{117}$ A year later, he returned to Paris, and it was around then that his music started being performed publicly

\footnotetext{
111 Trickey, 50.

112 Ibid., 51.

${ }^{113}$ Ibid., 7.

${ }^{114}$ Ibid.

${ }^{115}$ Ibid.

${ }^{116}$ Daniel, 30.

117 Trickey, 7.
} 
and Les Nouveaux Jeunes took shape. ${ }^{118}$ At one of these first concerts in 1917, his work Six poèmes extraits de Alcools was premiered along with Auric's Gaspard et Zoè, Durey’s Carillons, Tailleferre's Sonatine à cordes, and Roland-Manuel's Sept poèmes de Perse.

As Milhaud recalled, the members of Les Six did not share much aesthetically apart from friendship and an appreciation for melody. Honegger confirmed this when he said that "his association with Milhaud had nothing to do with the restriction of the independence of either party... [he was a] fervent zealot of Satie... and finds himself unable to join [him] in his cry, 'A bas Wagner!""119 Honegger much preferred the music of Bach, was well-versed in Classical and Romantic music, particularly Strauss and Reger, and was influenced by Stravinsky and Schoenberg. ${ }^{120}$ He credited Fernand Ochsé, a French musician and painter he met at the Conservatoire, as one of the most influential people in his life. Honegger dedicated two works to him—his 1918 ballet Le Dit des Jeux du Monde and his 1930 operetta Les Aventures du Roi Pausole. Ochsé was friends with Ravel and Hahn, and he had his hand in many different projects between 1900 and 1940. Tragically, he and his wife were captured by the Nazis and murdered in 1944 at the Drancy extermination camp.

Honegger's early compositional style can be described as short pieces with a tendency for "predominance of linear texture; at times considerable chromaticism of linear motivation, and a general absence of "pianistic" features such as octaves, scales, arpeggios."121 He had a "preference for small forms or sets of small pieces; this is, in fact, true of most works in his rather small output for the [piano], with exception of his fairly substantial Toccata et variations

\footnotetext{
118 Trickey, 7.

${ }^{119}$ Ibid., 58.

${ }^{120}$ Ibid.

${ }^{121}$ Michael R. Sitton, "The Album Des Six and Pianism in the Works of Les Six, 1917-1925" (DMA diss., University of Illinois at Urbana-Champaign, 1991), 81, ProQuest Dissertations and Theses Global.
} 
from 1916. The absence of other large piano works in his oeuvre surely demonstrates his lack of interest in the instrument." 122

Sensing a common thread amongst the members of Les Six, Tailleferre's parents did not want her to go to the Conservatoire. Born in the Southeast of Paris as Germaine Taillefesse, she changed her last name to Tailleferre to disown and distance herself from her father who was the main obstacle in her pursuit of a musical career. ${ }^{123}$ At the Conservatoire, she was a remarkable student, winning first prizes in solfège, harmony, counterpoint, and accompaniment. Milhaud described her as

a delightful musician. She writes slowly but with sureness. She produces little but each work is remarkably mise au point. Her music has the great merit of being without pretension; it is most attractive because it is sincere. It is really the music of a young girl in the most lovely sense of the word. It is so fresh that one would almost say that it is scented. Her tendencies have left her rather in sympathy with the Impressionists from whom she inherited the love of subtle chords and perfection in details. ${ }^{124}$

Tailleferre met Milhaud, Auric, and Honegger at the Conservatoire, forming the beginnings of Les Nouveaux Jeunes. She remembered those times after the war began fondly_-"we spent long days in Milhaud's flat since classes were empty... He initiated us into Stravinsky, Magnard, Debussy, etc., in short, everything the Conservatoire despised and rejected! Everything that delighted us!" 125 She admired Bach, Couperin, and Mozart, but she was never able to escape her perceived associations with Impressionists. In L'Album des Six, Tailleferre's movement Pastorale displays this harmonic "subtleness," expressing Milhaud's sentiment that her music was almost "scented." Pastorale is "a playful and busy-textured [piece] which

\footnotetext{
122 Sitton, 81.

${ }^{123}$ Trickey, 70.

${ }^{124}$ Ibid., 5.

${ }^{125}$ Sitten, 11.
} 
ventures into harmonically ambiguous territory... and formally the best description of the piece is certainly 'through-composed'... until the slowing, softening close... is reached."126

Born in the south of France, Auric was considered a child prodigy, and by the age of ten was composing and performing on piano. In 1913, his parents moved to Paris so he could study at the Conservatoire. He attended the same classes that the other members of Les Six did but he also went to the Schola Cantorum de Paris, a counterpart school to the Conservatoire run by d'Indy. Auric's aesthetic preferences for Satie and Cocteau are very apparent, made mostly due to their close friendship and working relationship. ${ }^{127}$ Cocteau seemed to favor Poulenc and Auric the most, dedicating his Le Coq et l'Arlequin to Auric. ${ }^{128}$ Like Poulenc, Auric's other compositional influences leaned in the direction of Chabrier and Messager. ${ }^{129}$ In 1920, Auric premiered his foxtrot Adieu, New York, a piece that explored American jazz. ${ }^{130}$ Trickey mentions that among the other members of Les Six, Auric did not speak out publicly about his early personal preferences for music, taste, and compositional practices. ${ }^{131}$ Instead there are "certain traits to be dominant in Auric's music: a conciseness of expressions, a clarity that derives from a lively intelligence, a sharp sting of acerbity, a firmness of purpose, a marked reserve, and a scrupulous concern for the complete avoidance of self-delusion." 132

Durey was the oldest member of Les Six, born in 1888 in Paris. He started his music career very late and, similarly to Poulenc, he never attended the Conservatoire. Instead, he attended the Schola Cantorum between 1910 and 1914. Trickey mentions that Durey was

\footnotetext{
${ }^{126}$ Sitton, 70.

${ }^{127}$ Trickey, 66.

${ }^{128}$ Daniel, 33.

129 Trickey, 67.

${ }^{130}$ Sitten, 32.

${ }^{131}$ Trickey, 67.

${ }^{132}$ Ibid.
} 
"known as a retiring person who preferred obscurity which he deliberately sought" 133 and this makes sense. By 1921, Durey was already severing his ties with Les Six by rejecting Cocteau's offer to contribute to Les Mariés de la tour Eiffel. Trickey goes on to say that he was only briefly influenced by Satie, and instead that "his heart does not ever seem to have been with the innovators and all his subsequent music has shown that his natural affinity is rather with the older generation of Debussy and Ravel." ${ }^{134}$ A perfectionist, Durey flirted with varying styles at different times, at one point with Schoenberg and atonality, with Satie and the "New Spirit," and another time with the great Impressionists. ${ }^{135}$

Durey's attachment to the French communist party after his departure from Les Six complicated his musical career for the rest of his life. It started when he rejected Cocteau's Les Mariés de la tour Eiffel offer. Like Auric, Durey had been associating himself with people Satie did not like, further widening the divide between them. This time it was with Ravel:

To his great dismay Durey decided not to participate; he had in fact already estranged himself by associating with Ravel, to whom Satie was at the moment violently opposed, and by moving his family to Saint Tropez, from which residence he would become increasingly involved in the leftist political causes which would, largely, thereafter consume his passions. Cocteau was annoyed by this show of independence. It was as if a canvas on which he was a painting had suddenly got up and walked away. His authority had been contested. In a poem addressed to the Six, he testily omitted Durey's name. ${ }^{136}$

In summary, Trickey shows that even though each member of Les Six chose different paths early on, certain identifiable features can be observed across all of them. The first of these unifying forces was “youthfulness." These composers worked together closely starting in 1917, and it wasn't until Collet named them that they were launched onto a worldwide platform. By

\footnotetext{
${ }^{133}$ Trickey, 71.

${ }^{134}$ Ibid.

${ }^{135}$ Ibid.

${ }^{136}$ Sitton, 35.
} 
that time, Poulenc and Auric were already twenty-one, Milhaud, Honegger, and Tailleferre were twenty-seven, and Durey was thirty-one. Trickey says

this quality of youthfulness is important. The history of man and the history of music have been marked by a period of rejuvenation, revolution, or reaction stemming from a desire to move in new directions of artistic and creative effort, and youthfulness has been a prominent characteristic of those who have rallied to the support of such causes. ${ }^{137}$

As such, it was their youthful disposition in a war-torn Europe and reaction to abandon the older ways that no longer served them. Secondly, Trickey mentions their "spirit of independence." Throughout their early careers, all six members displayed some degree of this defiant spirit: Milhaud, Poulenc, and Honegger through their personalities and actions, Auric by defying Satie and befriending his enemies, Tailleferre by disowning her anti-music father and winning numerous prizes at the Conservatoire, and by Durey leaving Les Six to pursue his political passions. The final aesthetic Trickey refers to is that they knew "they were of their time."138 This was brought on by Collet, who launched them onto the worldwide platform. Milhaud seemed to understand this more than the others because he was aware of the importance of the name and the publicity that came with it. He disliked being put on a pedestal, having said:

I disapproved fundamentally of communal aesthetic theories and considered them a limitation, an unreasonable brake on the imagination of the artist who must, for each new work, find different and often opposing means of expression; but resistance was useless! Collet's article made such an international splash that the "Groupe des Six" was founded and I was a part of it, whether I liked it or not. ${ }^{139}$

Although Les Six existed briefly, they made the most of their time together while they could. If it were not for their interpersonal relationships, how they were all at the right place at the right time, and how they reacted the way they did to world events, they never may have

\footnotetext{
${ }^{137}$ Trickey, 78.

${ }^{138}$ Ibid., 79.

${ }^{139}$ Nichols, 37.
} 
existed. It was by their friendship stemming from the Conservatoire and these chance happenings that brought them together. Their union came to represent the period of time after Parade.

\section{A List of Their Oboe Works}

In this section, smaller oboe works by Les Six are listed to assist the reader with the timely context of the Poulenc oboe sonata among those compositions. The list is sorted in order of who was born first (providing chronological context), the year the pieces were composed, and by opus numbers or catalogue systems where applicable. All instrumentation is included, while avoiding larger ensembles, film scores, and orchestral pieces. Some catalog numbers do not match with the year of composition, indicating that there may be an error in Carl B. Schmidt's (Poulenc) and Harry Halbreich's (Honegger) cataloging systems. The other four composers correctly align with their labeling systems and year of composition.

\section{Louis Durey (1888-1979)}

Trois Chansons Basques for voice, oboe, English horn, clarinet, and bassoon, Op. 23 (1919)

Les Soirées de Valfre for wind quintet, Op. 96 (1963)

Divertissement for oboe, clarinet, and bassoon, Op. 107 (1967)

Trois Pièces Brèves for oboe solo, Op. 115 (1974)

Arthur Honegger (1892-1955)

Antigone for oboe, English horn, and harp, H. 45 (1922)

Three Counterpoints for flute, oboe, violin, and cello, H. 43 (1929)

Concerto da camera for flute, English horn, and strings, H. 196 (1948)

Germaine Tailleferre (1892-1983)

Partita for oboe, clarinet, bassoon, and strings (1962)

Sonate champêtre for oboe, clarinet, bassoon, and piano (1972)

Rondo pour hautbois et piano (1973)

Menuet for oboe and piano (1975)

Menuet en Fa for oboe, clarinet, bassoon, and piano (1979) 
Darius Milhaud (1892-1974)

Sonate for Flute, Oboe, Clarinet, and Piano, Op. 47 (1918)

Pastorale for oboe, clarinet, and bassoon, Op. 147 (1935)

Suite d'après Corrette for oboe, clarinet, and bassoon, Op. 161b (1937)

La cheminée du roi René for wind quintet, Op. 205 (1939)

4 Ésquisses for wind quintet, Op. 227b (1941)

Les rêves de Jacob, dance suite for oboe and string quartet, Op. 294 (1949)

Divertissement for wind quintet, Op. 299b (1958)

Sonatina for Oboe and Piano, Op. 337 (1954)

Concerto for Oboe and Orchestra, Op. 365 (1957)

Stanford sérénade for oboe solo, flute, clarinet, bassoon, trumpet, harp, two violins, viola, cello, string bass, and percussion, Op. 430 (1969)

Wind Quintet, Op. 443 (1973)

Francis Poulenc (1899-1962)

Quatre poèmes de Max Jacob for voice and wind quintet, FP. 22 (1921)

Trois mouvements perpétuels for wind quintet and string quartet, FP. 14b (1925)

Trio for Oboe, Bassoon, and Piano, FP. 43 (1926)

Sextour for wind quintet and piano, FP. 100 (1932)

Suite française d'après Claude Gervaise for 2 oboes, 2 bassoons, 2 trumpets, 3 trombones, percussion, and harpsichord, FP. 80a (1935)

Sonata for Oboe and Piano, FP. 185 (1962)

Georges Auric (1899-1983)

Trio for Oboe, Clarinet, and Bassoon, GA. 114 (1938)

Impromptu for oboe and piano, GA. 164 (1946) 


\section{Chapter 3}

\section{The Oboe Sonata (1962-1963)}

The Oboe Sonata, Poulenc's last significant work, is imbued with a serene gentleness and a peaceful resignation that could have come only from a man who had achieved contentment with his life and his music.

—Keith Daniel, Francis Poulenc

The oboe sonata can not be discussed without mentioning Poulenc's other stand-alone wind sonatas - the clarinet and flute sonatas. Many thematic and melodic elements are shared between them, making it easier to explore them together. Originally, Poulenc may have begun composing them as early as 1957 after he became bored listening to his vocal works. ${ }^{140}$ The flute sonata, however, was conceived much earlier, in 1952. Harold Spivacke, Chief of the Music Division at the Library of Congress at the time, attempted to commission Poulenc to compose chamber works for two pianos or small ensembles to which Poulenc declined. ${ }^{141}$ He was too busy with work and travel to consider taking on more projects. Spivacke pressured him further until Poulenc finally agreed, but only if it were a piece for woodwinds. Poulenc said, "I have always adored wind instruments, preferring them to strings, and this love developed independent of the tendencies of the era [c.1915-1925]. Of course, L'Histoire du Soldat and Stravinsky's solo clarinet pieces stimulated my taste for winds, but I had developed the taste as a child."142

The flute sonata was completed and premiered in 1957 by flutist Jean-Pierre Rampal with Poulenc at the piano. It was dedicated to Elizabeth Sprague Coolidge, a prominent American pianist and patron of music. He said of the work, "in working on this flute sonata I have the

\footnotetext{
${ }^{140}$ Nichols, 278.

${ }^{141}$ Schmidt, 408.

142 Daniel, 201.
} 
feeling of going back a long way, but with a more settled technique. It's a sonata of Debussyan dimensions. It's the French sense of balance... It's what Webern had in the highest degree and what Boulez has not yet found." ${ }^{143}$ Poulenc also said that the flute sonata was "sans complexes," $" 144$ a comment with an almost Satie-like undertone suggesting a return to uncomplicated music. With the flute sonata he was caught in a whim of nostalgia, reminiscing on a period of time over half a century ago.

With the immediate success of the flute sonata and subsequent publications, Poulenc was motivated to complete the remaining three. At the time, he had just finished incidental music for Cocteau's play, Renaud et Armide, but remained unimpressed with his own vocal works. ${ }^{145}$ Finding renewed momentum, he revisited his sketches of the clarinet and oboe sonatas that he had been "stewing in the same pot" since $1957 .{ }^{146}$ There was another reason for his revived interest in these works - the ten year anniversary of Prokofiev's death (1963) was approaching, and even though their friendship ended at a Parisian bus stop thirty years ago, he still respected him immensely. This sad event was the inspiration for their creation, source material, and the subsequent oboe dedication. ${ }^{147}$ The clarinet and oboe sonatas, hence, were deeply personal projects for Poulenc. He valued his friendships dearly and was extremely aware of death and hardship, especially having served in the military during both World War I and World War II. It was

clear from his correspondence that he cherished his friends and took it very hard when any of them passed away. Many friends were persecuted and killed during the war, in Nazi death camps and during the French Resistance; the only woman he ever loved died

\footnotetext{
${ }^{143}$ Nichols, 251.

${ }^{144}$ Ibid.

${ }^{145}$ Nichols, 278.

${ }^{146}$ Ibid.

${ }^{147}$ Margaret J. Grant, "A Feminist Analysis Of Francis Poulenc's Sonata For Oboe And Piano" (DMA diss., University Of Cincinnati, 2006), 75, ProQuest Dissertations and Theses Global.
} 
young ${ }^{148}$; he anguished over Denis Brain's premature death; he lost his own parents while still a teenager. Burton writes, "If Poulenc's work is haunted by the omnipresence of violent, tragic or premature death, the reason is in large part to be found in the holocaust of his personal friends." 149

Poulenc typically dedicated his works to one of his many friends, although often denying that they were associated with any particular person or event. ${ }^{150}$ Grant makes the suggestion that it would be interesting to review these dedications as a window into his life, especially since he was so well connected. ${ }^{151}$

In the case of the oboe sonata, it was his last piece. ${ }^{152}$ It takes direct source material from the other two wind sonatas, reusing themes and figures found throughout them. Some of those thematic elements come directly from his operas La voix humaine and Dialogues de Carmélites, and Prokofiev's fourth and fifth piano sonatas. This makes sense, however, since the flute sonata was one of the first major works he composed after Carmélites. ${ }^{153}$ Poulenc would have been very familiar with Prokofiev's first four piano sonatas, since they were composed long before they met in 1921. Poulenc even said that he prefered them over his later ones (with special exception to his sixth and seventh, citing them as not being played enough). ${ }^{154}$ The source materials for these compositional similarities are discussed in the wind sonatas review.

The final two wind sonatas for clarinet and oboe, respectively, are a presentation of Poulenc's mature and deeply reflective style. Daniel accurately describes them as "the most perfect examples of Poulenc's mature art: serene, profound, lyric, and ideally proportioned.’155

\footnotetext{
${ }^{148}$ Poulenc was also openly gay, having been in several relationships with men during his lifetime.

${ }^{149}$ Grant, 74.

${ }^{150}$ Nichols, 19.

${ }^{151}$ Grant, 65.

152 Daniel, 250.

${ }^{153}$ Ibid., 247.

${ }^{154}$ Poulenc and Audel, 123.

${ }^{155}$ Daniel, 126.
} 
He adds that "the chamber works are generally lighthearted and tuneful, often saucy and tongue-in-cheek; in this sense, they retained, throughout Poulenc's fifty-year career, the imprint of Parisian popular music (cafe-concert and music-hall) and the aesthetic of Les Six." ${ }^{156}$

Thus, these sonatas are our final glimpse into his sound world. It is a presentation of the many different jigsaw pieces that encompass the artist at the peak of his bourgeoisie style. With them we gain a better understanding of his late unified form and why they share so many thematic elements amongst them. The sonatas come to represent his sincere devotion to his friends - by taking entire melodies from their works and recomposing them with dedication. They are "the culmination of Poulenc's chamber genre, both chronologically and stylistically." 157

\section{An Unusual Pair}

Poulenc's and Prokofiev's friendship was quaint in that it was really odd for a Frenchman and a composer from the USSR to be best friends. They met first in 1921 at the Hôtel Continental at the invitation of Diaghilev, who was coordinating the production of Chout, a two-part ballet by Prokofiev. ${ }^{158}$ Poulenc did not recall much of Prokofiev at that time, saying, “[he was] all silence. I don't think I've remembered four sentences, four words, from [him] at that lunch." ${ }^{159}$ Poulenc mentioned later that he spoke French very well, so for him not to have said a word was very awkward. Prokofiev was a quiet man and exclusive with his friendships, choosing specific people to include in his inner circle. ${ }^{160}$ So it is odd then that Prokofiev warmed up to the much younger Poulenc; when they first met he was thirty and Poulenc was twenty-two. Similarly to Vidal, Prokofiev was not shy about how he felt Poulenc's compositions sounded. He

\footnotetext{
${ }^{156}$ Daniel, 200.

${ }^{157}$ Ibid., 254.

${ }^{158}$ Poulenc and Audel, 114.

${ }^{159}$ Ibid.

${ }^{160}$ Ibid.
} 
"thought badly of [them], badly."161 It seemingly made sense that Poulenc assumed Prokofiev thought nothing of him when they first met, but rather, he did not know that Prokofiev was simply a very private and selective person. ${ }^{162}$ However, around 1923, Poulenc mentions, was when things changed. Their differences did not seem to matter much anymore, with Audel saying that "of all the musicians Prokofiev met [in Paris], [Poulenc] was the only one he became friendly with." 163

Their friendship became based on two things - playing piano and Bridge. Poulenc helped him practice his concertos by playing the orchestral parts, and they attended Bridge tournaments together. Prokofiev may have used these occasions to feel more secure in his own piano playing, still dealing with his "problematic hand positioning, which took [him] many years to overcome." ${ }^{164}$ Prokofiev took extra care when it came to Poulenc and his personal finances, too. Poulenc had lost money in a previous tournament they went to, and a concerned Prokofiev found a Bridge competition in the United States for him to enter which offered $\$ 25,000$ as the pot (more than $\$ 430,000$ today). ${ }^{165}$ After Poulenc's death, Mme Milhaud recounted a similar hilarious story involving his problems with money:

He had his anxious side. And one has to admit, he was rather-how do you say? - "close" with money. I remember at a party Darius and I gave, he found one franc on the carpet and was going round the room asking "C'est à vous? C'est à vous?" Eventually I said to him, "For Heaven's sake Francis, put it in your pocket!"166

Poulenc went to Prokofiev's home every week between 1931 and 1932, with Jacques Février, a famous French pianist, Alexander Alekhine, the world chess champion at the time, and

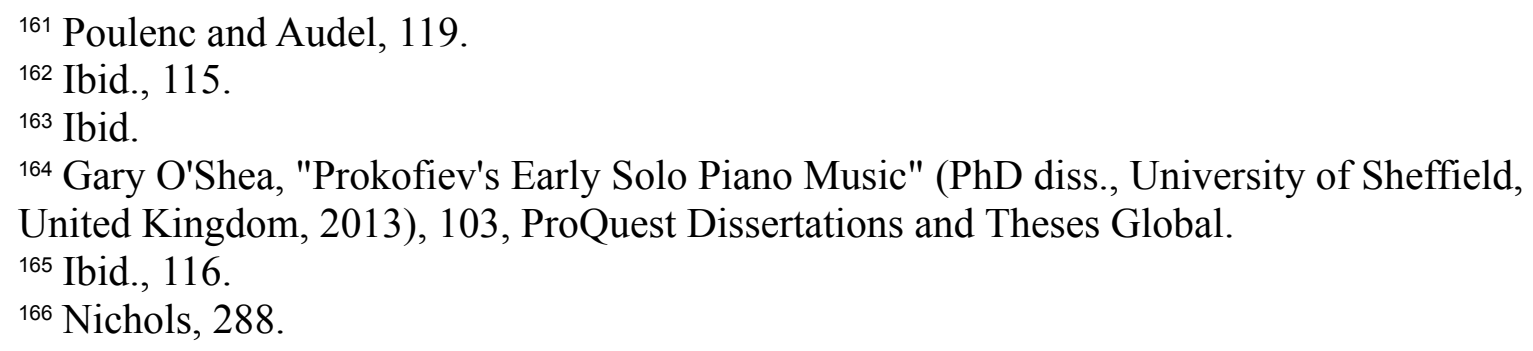


an unnamed Russian woman to play Bridge. If he arrived early, "music was an extra... we'd have a cold dinner and play music for four hands... that's the point where my friendship with Sergei crystallized." ${ }^{167}$ That moment must have been magical for Poulenc. He revered

Prokofiev's piano playing, and he gasped when recalling it:

Ah!... Prokofiev's playing!!! It was marrrvellous! I worshiped [it]... he played on a level with the keyboard, with an extraordinary sureness of wrist, a marvellous staccato. He rarely attacked from on high; he wasn't at all the sort of pianist who throws himself from the fifth floor to produce the sound. He had a nervous power like steel, so that on a level with the keys he was capable of producing sonority of fantastic strength and intensity, and in addition - I recommend this to all players of Prokofiev - the tempo never, never varied. ${ }^{168}$

This unusual friendship came to an unusual end, however. Prokofiev left Paris for good in 1932 and Poulenc never heard from him again. ${ }^{169}$ He was one of the last few people to see Prokofiev in Paris, having walked him to his bus stop where he recalled Prokofiev saying "a bientôt" $" 170$ to him. Poulenc replied, "write to me... and I never received anything, he went back to Russia and I never heard anything more from him." ${ }^{171}$ Poulenc displayed confusion here because Prokofiev went to the United States first in 1932, later recalling this himself. ${ }^{172}$ O'Shea confirms that Prokofiev was back in the USSR by 1936, so during this period of four years Prokofiev was touring internationally but never returned to France. ${ }^{173}$ Poulenc had hoped that one day they'd talk or meet again, but his attempts to reach Prokofiev failed. Once in Brussels, he met an unnamed Soviet leader of music and asked him to pass on a message to Prokofiev, but

\footnotetext{
${ }^{167}$ Poulenc and Audel, 116.

${ }^{168}$ Ibid., 120.

${ }^{169}$ Ibid., 124.

${ }^{170}$ Ibid., 123.

${ }^{171}$ Ibid., 124.

172 Ibid., 119.

${ }^{173}$ O'Shea, 112.
} 
whether that message made it to him is unknown - "[he had] no clue."174 Their friendship had effectively ceased the moment he left France.

During this period of time, the USSR was under the totalitarian rule and iron fist of Joseph Stalin, and the political and humanitarian situation was extraordinarily dire. A famine from 1932 to 1933 caused between five to seven million people to die, ${ }^{175}$ judicial executions were commonplace, totalling almost eight hundred thousand deaths; ${ }^{176}$ and millions of others were forcibly relocated or sent to die at labor colony prisons, known as Gulags, in Siberia. ${ }^{177}$ It was not a safe place to live or work, especially as an artist returning from a free country-something Audel mentions in his interviews with Poulenc, saying, "there were certain rules that had to be observed over there." ${ }^{178}$ We can only speculate that Prokofiev was forced to stop all communication with Poulenc and others outside of the curtain for fear of his life and his family's lives. O'Shea somewhat confirms this isolation because he was banned from leaving the Soviet Union in $1938 .{ }^{179}$

Poulenc does not make it clear, but at some point while he was running errands many years later, he ran into the same unnamed Russian lady who attended Prokofiev's at-home Bridge tournaments. ${ }^{180}$ They talked about Prokofiev, who was now back in the USSR, and she said when she spoke with Prokofiev, he said to her that he was actually "mistaken, [that] Poulenc is a real musician." 181 This chance exchange consoled Poulenc greatly, who had thought Prokofiev hated

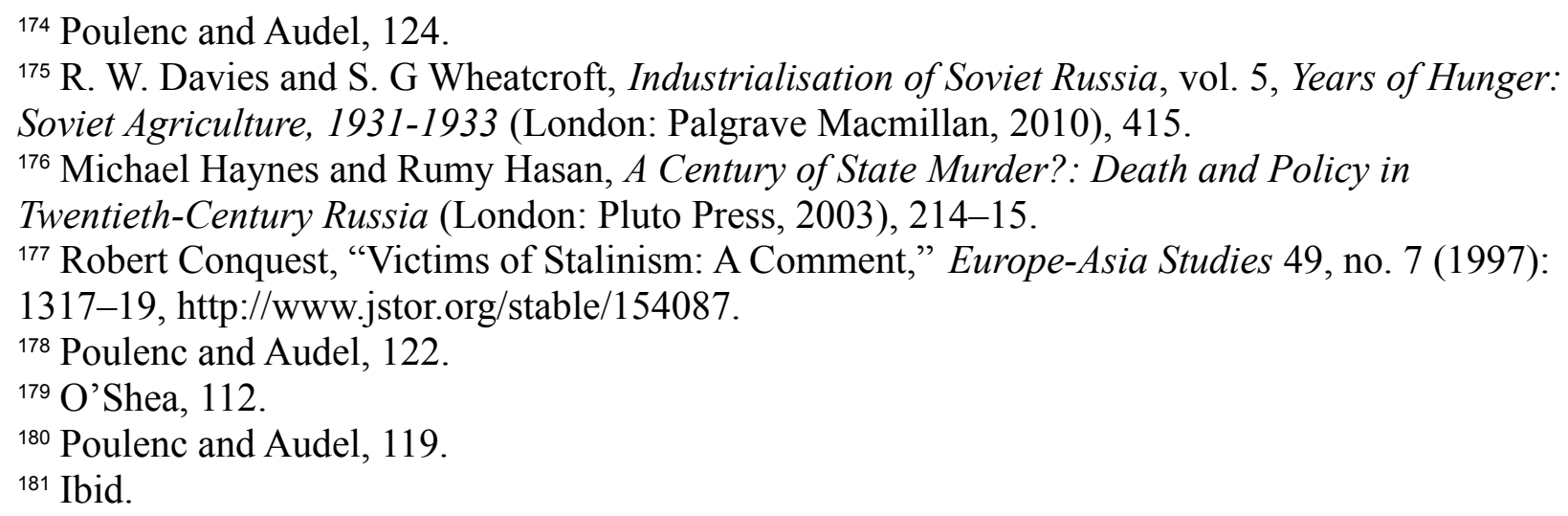


his music. He was a person who cherished memories of his friends, and he referred to them as some of his happiest times. ${ }^{182}$

\section{The Dedication to Sergei Prokofiev}

"Where [do I] go now?" 183 is a question Poulenc frequently asked himself, especially when he grew bored of his own works. Rather than continue composing vocal music, Poulenc took a special interest in composing for solo winds. By 1957, he had already finished the flute sonata, so he set out to conceptualize the clarinet, bassoon (never finished), and oboe sonatas from his sketches. He dedicated the clarinet sonata to his lifelong friend and co-member of Les Six, Arthur Honegger, and the oboe sonata to Sergei Prokofiev. Grant suggests that further investigation into the dedication is necessary due to the programmatic elements of the unusual setting in the oboe sonata. She notes that the movements do not follow the typical tempo layout expected of sonata form (fast-slow-fast), and instead, it is reversed (slow-fast-slow) ${ }^{184}$ This seemingly extramusical element from the dedication is intentional and makes sense here considering the titles of each of the movements (Élégie, Scherzo, and Déploration) relate to Prokofiev's death and the end of their friendship.

The dedication to Prokofiev becomes more interesting then when examining these elements and it explains why the first movement of the oboe sonata, Élégie, is just that—-"both a consolation and a lament." ${ }^{185}$ Elegies are typically poems mourning the dead, and in this case, Poulenc was mourning the death of his friend. The following movement, Scherzo, features a snapshot of one of Prokofiev's more preferred styles; it is a sparkly depiction of Prokofiev's own

\footnotetext{
${ }^{182}$ Poulenc and Audel, 119.

${ }^{183}$ Nichols, 278.

${ }^{184}$ Grant, 75.

${ }^{185}$ Nichols, 282.
} 
piano playing interrupted by a slower and more sensuous middle section, le double plus lent. Nichols suggests this unusual section features Pokofiev's ability to compose expressive melodies. While I agree with Nichols on the nature of this slower area, I cannot help but think how Poulenc vocalized the oboe part. Poulenc was a great composer for voice and he set the oboe part here as if it were one, where each note could easily be set to text (in the syllabic style he preferred). It is imaginable then that Poulenc, hot off the heels of the flute sonata and Carmélites, inserted a "song" into the middle of the Scherzo creating this almost vocal-like interlude. In the last movement, Déploration, Nichols reminds us that Poulenc "pays deference to the déplorations that early French composers like Josquin and Ockeghem" wrote for their teachers. ${ }^{186}$ And so here, too, Poulenc pays tribute to Prokofiev in the traditional French sense as students would do for their teachers in the past.

Poulenc, in his own words, worshipped Prokofiev and his piano playing. He cherished the moments they shared at his home as some of his most valued memories. He lamented the tragic end of their friendship and wished they had reconnected at some point. The oboe sonata is a testimony of that brief time but also a homage to Prokofiev.

Attributed as his last work, the sonata and its last movement Déploration take on a double meaning - it spelled the end for Poulenc. He had suffered greatly during his lifetime with hypochondria and depression, and he was becoming increasingly more aware of his own mortality and legacy. His health had been steadily declining, spiked by severe episodes of angina (chest pain brought on by a lack of blood flow to the heart that is commonly associated with coronary artery disease). ${ }^{187} \mathrm{He}$ had been diagnosed with high blood pressure in 1954 and was on a strict diet. ${ }^{188}$ During a trip to Milan in February with soprano Denise Duval, he contracted

\footnotetext{
${ }^{186}$ Nichols, 282.

${ }^{187}$ Ibid., 283.

${ }^{188}$ Ibid., 279.
} 
severe bronchitis. He returned to Paris after being treated by a doctor and "stuffed" with penicillin. ${ }^{189} \mathrm{He}$ expressed in a letter to famous baritone Pierre Bernac that he was "dying for wind, humidity, and flowers." ${ }^{190}$ Despite his ailing health, Poulenc continued to compose and travel, even giving a short concert tour with Duval in Belgium and Holland. ${ }^{191}$ In 1962, Poulenc spent the remaining winter months copying the clarinet manuscript and finishing the oboe sonata, but on January 30, 1963, he died of a suspected heart attack. ${ }^{192}$ Both works were premiered later that year - the clarinet sonata by clarinetist Benny Goodman and conductor Leonard Bernstein on piano; and the oboe sonata by oboist Pierre Pierlot and pianist Jacques Février.

\section{Prokofiev's Early Style}

A short biographical investigation is necessary to convey what Prokofiev's early style was like, and what Poulenc would have been familiar with in his own compositions. Prokofiev was born in 1891 (putting him in the same age group as Honegger, Milhaud, and Tailleferre) in a remote and small village, Sontsovka, which is now located in modern day Ukraine. Much like Poulenc, his mother was pivotal in his early music education. She gave him his first piano lessons, although she was limited in her ability. ${ }^{193}$ He was taught by her until 1902, when he was passed over to composer Reinhold Glière. Not a very talented pianist himself, Glière was unable to help Prokofiev fix hand position problems he developed while studying with his mother. ${ }^{194}$ Prokofiev said that

he played the piano with great ease and confidence, although his technique left much to be desired. He played carelessly and did not hold his hands together properly on the

\footnotetext{
${ }^{189}$ Nichols, 279.

${ }^{190}$ Ibid.

${ }^{191}$ Daniel, 126.

${ }^{192}$ Nichols, 279-83.

${ }^{193}$ O'Shea, 103.

${ }^{194}$ Ibid., 104.
} 
keyboard. Sometimes he managed difficult passages with comparative facility but at other times he could not play a simple scale or an ordinary arpeggio. ${ }^{195}$

Two years later, Prokofiev was accepted to the St. Petersburg Conservatory, and after taking his piano entrance exam, he was told that he read music aptly but his technique was poor. ${ }^{196}$ Alexander Winkler took him on as a student, making him study Beethoven piano sonatas and Bach fugues. ${ }^{197}$ Winkler aided Prokofiev in fixing his hand position problem, with both Glière and Alexander Glazunov (the director of the school of music then) noticing technical improvements. Glazunov even shared that he had a "brilliant technique, [and] beautiful tone."198 O'Shea brings attention to Prokofiev's diary, saying he was aware that he had the ability to be a pianist, but also rarely practiced for an hour a day. ${ }^{199}$ At Glazunov's suggestion, he switched to Anna Yesipova's studio (whom Prokofiev later married) to become a better pianist because "Winkler [was] a first-class musician, [while] Yesipova is a pianist and he is not." ${ }^{200}$ Yesipova instructed him on works by Bach, Handel, Mozart, Beethoven, and Mendelssohn, and even provided criticism of his newly-composed first piano sonata as "over-pedalled and all fortissimo." ${ }^{201}$ Some of his other classes included orchestration with Rimsky-Korsakov, Glazunov, and Lyadov. ${ }^{202}$

After winning the Anton Rubinstein Piano Competition in 1914 with his own first piano concerto, Prokofiev left the conservatory to pursue his career as a concert pianist and composer. ${ }^{203}$ His early recital programs featured his music almost exclusively, featuring his piano

\footnotetext{
195 O'Shea, 104.

${ }^{196}$ Ibid.

${ }^{197}$ Ibid.

${ }^{198}$ Ibid.

${ }^{199}$ Ibid.

${ }^{200}$ Ibid.

${ }^{201}$ Ibid., 106.

${ }^{202}$ Ibid., 3.

${ }^{203}$ Ibid., 107.
} 
sonatas among his other works. He traveled during this period of time, giving performances of his first piano concerto, third piano sonata, and his Classical Symphony at Carnegie Hall. ${ }^{204}$ The reviews of these works were not kind:

Prokofieff uses, like Arnold Schonberg, the entire harmonies. [...] He is a psychologist of uglier emotions - hatred, contempt, rage — above all rage — disgust, despair, mockery, and defiance legitimately serve as models for moods. Occasionally there are moments of tenderness; exquisite jewels that briefly sparkle and then melt into seething undertow. The danger in all this highly spiced music is manifest; it soon exhausts our faculty of attention $[\ldots] .{ }^{205}$

This review changed his approach to the stage in the United States, in part by choosing more "palatable" programs for his future performances. ${ }^{206}$ In 1924, Prokofiev left the United States and traveled to Paris where he premiered his second piano concerto alongside Honegger's Pacific 231 to great success. ${ }^{207}$ For the next six years, Prokofiev gave public performances and premieres of his works back home in the USSR, United States, Brussels, London, and Paris, preferring major cities. O'Shea mentions that his most productive year as a performer was in 1930 while in Paris, where he "gave almost one concert each month." 208 This roughly coincided with the period of time Poulenc was visiting Prokofiev every week. Poulenc would have known many of Prokofiev's works given the frequency he performed them in Paris, seemingly confirming Poulenc's testimony. Prokofiev left Paris in 1932 where O'Shea cites Diagheliv’s death in 1929 as a potential reason: "Diaghilev had died the previous year and the Ballets Russes was consequently disbanded, starving Prokofiev of commissions. The move to the USSR, where collaborations were being discussed, must have looked even more attractive, and Prokofiev set

\footnotetext{
${ }^{204}$ O'Shea, 108.

${ }^{205}$ Ibid., 109.

${ }^{206}$ Ibid.

${ }^{207}$ Ibid., 111.

${ }^{208}$ Ibid., 112.
} 
about plotting his permanent return. ${ }^{209}$ It is at this point that Poulenc and Prokofiev's friendship ended and Prokofiev's permanent isolation in the USSR began.

During their interviews, Audel asked Poulenc about many things, but when asked to define Prokofiev's style, he answered:

F.P. To define Prokofiev's style... Stravinksy is a formidable innovator and Prokofiev isn't an innovator, but what does it matter? Schubert's not an innovator, either... Music wouldn't have changed if Schubert hadn't existed... Do you understand? You can be a great musician and still not be an innovator... yet you can be influenced by Prokofiev... I have myself, in certain little areas... But you can't say he was someone who made innovations like Debussy, like Schoenberg or Webern...

S.A. He wasn't a leader...

F.P. No. He was an excellent composer but he wasn't an innovator. ${ }^{210}$

Perhaps this is the same reason that Daniel struggles to define Poulenc's style, in that it is difficult to "describe a composer's style without resorting to meaningless and inflated generalizations." ${ }^{211}$ Rather than describing the entirety of Prokofiev's style, I will discuss his early period as Poulenc would have known up until 1932, drawing ideas from his fourth (1917) and fifth (1923) piano sonatas. Having written nine of them over a period of forty years, these initial sonatas can be characterized as "traditional in structure, displaying Russian influences in its debts to Skryabin and Medtner."212

The fourth sonata is "traditional in its focus on the primary chords; the minor to major idea in the recapitulation section is reminiscent of Beethoven's "Appassionata" Sonata."213 Prokofiev follows the three movement layout typical of sonata forms. The sonata's structure

${ }^{209}$ O'Shea, 112.

${ }^{210}$ Poulenc and Audel, 121.

${ }^{211}$ Daniel, 133.

${ }^{212}$ O'Shea, 100.

${ }^{213}$ Ibid., 101. 
makes sense given that Prokofiev had left the St. Petersburg Conservatory in 1914, where he studied mostly Germanic composers with both Winkler and Yesipova. O'Shea adds that the elemental nature of Prokofiev's musical ideas, displayed in compositions as early as the first sonata, is fundamentally Beethovenian, as is his superficial formal clarity. Prokofiev's melodies are often inconsistent in their phrase lengths, as sometimes are Mozart's. Creating tensions [that are] set up between symmetry and asymmetry. ${ }^{214}$

O'Shea brings up the experimental nature of the fifth sonata in that Prokofiev "lull[s] the listener into a false sense of security with conventionally structured ideas, such as those at the opening of the first and final movements, ${ }^{, 215}$ but he stays within the boundaries of the sonata form again. Perhaps this is a reason why Poulenc was convinced Prokofiev was not an innovator; he seemingly always fell back on traditional forms. O'Shea suggests the presence of Mozart in the opening melody, indicating a theme and accompaniment-like sensibility. ${ }^{216}$ The fifth sonata draws more comparisons to a "Parisian atmosphere" where the "modal writings of Ravel's and Debussy's styles come to mind." ${ }^{217}$ It's at this point where Prokofiev's music turns towards simplicity, perhaps as a reaction to the early beginnings of the neoclassical movement in Paris.

In summary, Prokofiev's early style was a testimony to the Germanic tradition, heavily influenced by Beethoven. He said of this, "I want nothing better, nothing more flexible, or more complete than the sonata form, which contains everything necessary to my structural purpose."218 He finds moments in these sonatas where he can "Prokofievize" (a term coined by his son) melodies by adding a wrong note or adding chromatic displacements, where temporary modulation happens. ${ }^{219}$ These would have been the styles and influences Poulenc referred to

\footnotetext{
${ }^{214}$ O'Shea, 102.

${ }^{215}$ Ibid., 100.

${ }^{216}$ Ibid., 119.

${ }^{217}$ Ibid., 100.

${ }^{218}$ Ibid., vii.

${ }^{219}$ Ibid., viii.
} 
when he composed the wind sonatas. These compositional elements are discussed in detail in the Wind Sonatas Review.

\section{Analyses Review}

The analyses review is a comparison of Margaret Grant, Keith Daniel, and Pamela Poulin's analyses of Poulenc's oboe sonata, Samuel Trickey's biographical investigation of the members of Les Six, and Siobán Ciulla's research documents_-all intellectual contributions in analyzing Poulenc's life and interpreting his work. Grant's exploration provides a previously untapped and unique approach through feminist scholarship. Grant suggests that "feminist music theory steps outside the bounds of traditional techniques, seeking ways to offer new kinds of music analysis that have more value to a wider audience." ${ }^{220}$ She adds that

feminist music theory may include musicological work and "celebrate multiple relationships between music, music theory and the cultures in which these relationships are developed." It is "process-oriented, including concepts of drama and myth, noting that myth includes rather than excludes truth." Feminist music theory avoids imposing an analysis on a work - an error often committed in traditional analysis. Killam states that theorists who impose an analysis on a work are creating "private power relationships" over the music. Feminist music theory, by contrast, recognizes that analyses reflect the individual analysts themselves. Because each analyst approaches a work out of her or his own contextuality, each analysis will be different. Therefore, the possibilities for multiple critical examinations of any one work are as numerous as the theorists who undertake to analyze it. ${ }^{221}$

While she applies feminist methods of analysis, she does so by still observing traditional theory when it's more suitable. An oboist herself, she mentions that her first attempt to analyze the sonata did not help her to perform or understand it any differently, and the only thing she discovered was that it did not follow the expected sonata form. She found that the absence of

\footnotetext{
${ }^{220}$ Grant, 2.
}

${ }^{221}$ Ibid., 38. 
traditional models necessitated the need for a new perspective. In her thesis, she contextualizes Poulenc by observing his personal life and musical style, and deconstructs already established ideas in traditional theory to transform and "reveal a more complete truth" 222 in the sonata. By doing this, she hopes to assist the oboist in achieving a better performance. She refers to the work done by Daniel, Hell, and Audel as the main source material for her research.

Daniel's contribution to Poulenc scholarship is the most substantial and comprehensive. Compiled in 1980, this biographical document is over six-hundred pages and provides an exhaustive exploration into the life of Poulenc, his music, and styles. At the time, only one such biographical account existed, authored by Henri Hell in 1959. Daniel notes the lack of a general survey of Poulenc's works, necessitating his research. Daniel presents an overview of select pieces (including the oboe and wind sonatas) for analysis and traditional observations. In the chapter in which he investigates the wind sonatas, he links them directly to each other, making mention of their timeliness, reused motivic materials, and compositional techniques.

Another traditional source comes from Poulin's 1983 thesis, “Three Stylistic Traits in Poulenc's Chamber Works for Wind Instruments," in which she provides a brief analysis of the sonata. She presents the formal layout, points to tonal relationships in and between movements, and lists the bars that are self-quoted from the other wind works. ${ }^{223}$ Like Daniel, she gives a biographical account of his early life and identifies the three stylistic traits that span the course of his career: Experimental, Neoclassical, and Popular. ${ }^{224}$ She says that his early works are indicative of his experimental period which "reflect some of the prevailing "mainstream" compositional tendencies in Paris in the 1920 s. ${ }^{225}$ She associates his neoclassical style with his

\footnotetext{
${ }^{222}$ Grant, 26.

${ }^{223}$ Poulin, 122.

${ }^{224}$ Poulin, iv.

${ }^{225}$ Ibid.
} 
middle and later works, citing Stravinsky as a major influence. She makes special mention of these techniques by listing them: "diatonic melodies, cyclic themes, textures, rhythms and harmony reminiscent of classic music, and quotations of themes, many of which are taken from some of Stravinsky’s own neoclassical works." ${ }^{, 26}$ Lastly, she notes the use of his Populist style consisting of "melodies and textures reminiscent of Parisian popular songs and music hall revues from the 20 s through the 40 s, modulating fifth relation harmony and syncopated rhythm.."${ }^{, 27}$ All of these styles coalesce in the oboe and clarinet sonatas.

Ciulla, while not performing an analysis of the Poulenc oboe sonata, instead provides a comparative analyses of two other works_-Poulenc's Trio for Oboe, Bassoon, and Piano (1926) and Françaix’s Trio for Oboe, Bassoon, and Piano (1994). She evidences neoclassical devices used by both composers that suggest the continuity of these techniques in chamber wind works from the first half of the twentieth century to the later half. And that by "studying both works it quickly becomes apparent that while Poulenc and Françaix used traditional formal models and tonalities for inspiration, they were still writing new music... as a result, a multitude of twentieth century compositional devices such as planing, octatonicism, and chromaticism are used to embellish the neoclassical music of these composers." 228

It is important to note that Milhaud, Poulenc, and others stated that the members of Les Six shared no aesthetical preferences and their relationship as a group was arbitrarily chosen by Collet. Instead, their association stemmed from a lifelong friendship that started in the early days at the Conservatoire and through their meetings with Satie, Viñes, and Cocteau. However,

\footnotetext{
${ }^{226}$ Poulin, Xv.

${ }^{227}$ Ibid., vi.

${ }^{228}$ Siobhán M. Ciulla, "Two Examples of Neo-Classicism in France from the Early and Late Twentieth Century: Francis Poulenc's Trio for Oboe, Bassoon, and Piano (1926) and Jean Françaix's Trio for Oboe, Bassoon, and Piano (1994)" (DMA diss., The Florida State University, 2017), vii, ProQuest Dissertations and Theses Global.
} 
Trickey suggests that they do share similarities, albeit they are contextual and not based on compositional styles or techniques. Instead, it was their youthfulness, spirit of independence, and knowing "they were of their time" that bound them together.

Unfortunately, Grant, Daniel, and Poulin, while covering the many different angles of the oboe sonata, never directly relate specific elements back to Prokofiev or Les Six. Instead, Prokofiev is mentioned in passing, usually as Poulenc's Bridge partner, and Les Six is an afterthought. Through these sources I will review the contextual principles shared by Les Six in the oboe sonata, and identify melodic content from Prokofiev's fourth and fifth piano sonatas that inspire some of the major themes. Lastly, the analyses review compares elements of Grant's feminist research with Daniel and Poulin's more traditional observations, and provides more theoretical terminology and suggestions offered by others.

A short investigation of the flute and clarinet sonatas will also assist in analyzing and understanding thematic elements and figures of the oboe sonata, which can be found in the Wind Sonatas Review.

\section{Wind Sonatas Review}

The opening line of Prokofiev's fifth piano sonata (Fig. 1) directly inspires the opening melody of Poulenc's flute sonata in an almost Mozart-like fashion (Fig. 2). Poulenc compresses the beginning 16 th notes to 32 nd notes while retaining the overall shape and phrasing of the line. In the fourth bar, he compresses the 16ths again but off-sets them to the weak subdivision of the second beat as a 32 nd septuplet. This creates an upward trajectory towards the high $\mathrm{C}$, the downbeat of the next bar. Poulenc takes the ascending quarter note line of the seventh bar from the piano sonata and inverts it in the flute sonata, creating a closed eight bar phrase ending on the tied quarter note B. 
Fig. 1 - Prokofiev, Piano Sonata No. 5, Mvt. I, opening

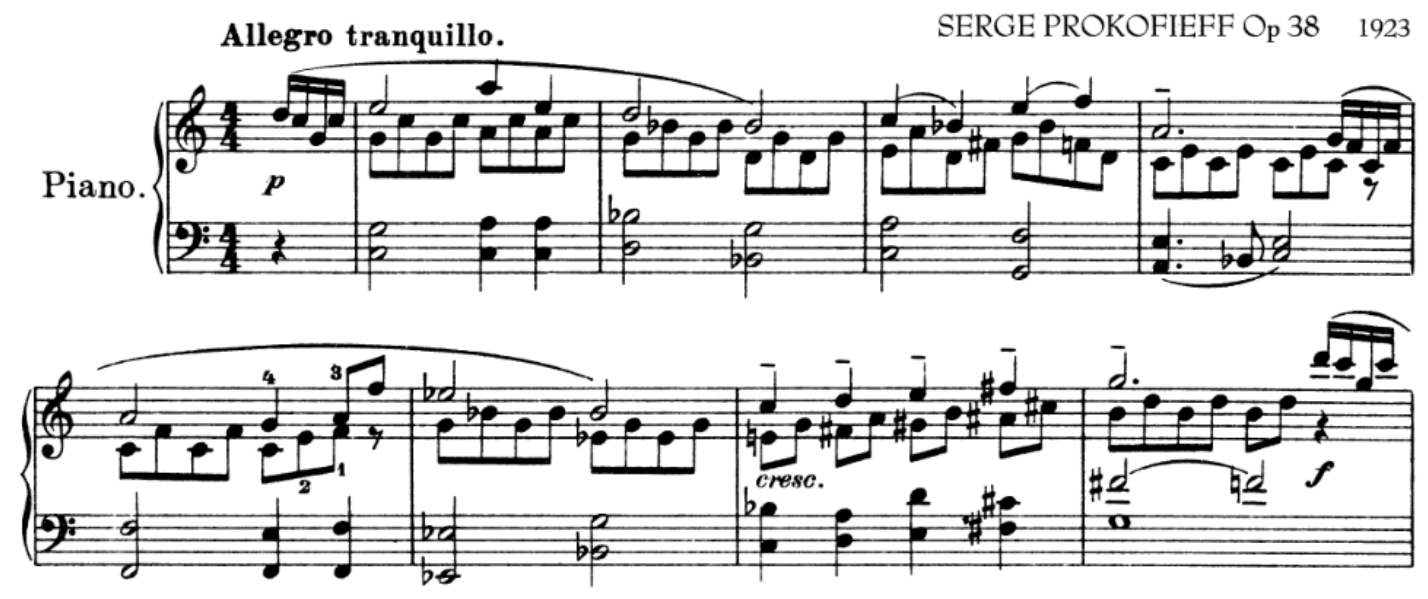

Fig. 2 - Poulenc, Flute Sonata, Mvt. I, opening

1. Allegro malinconico
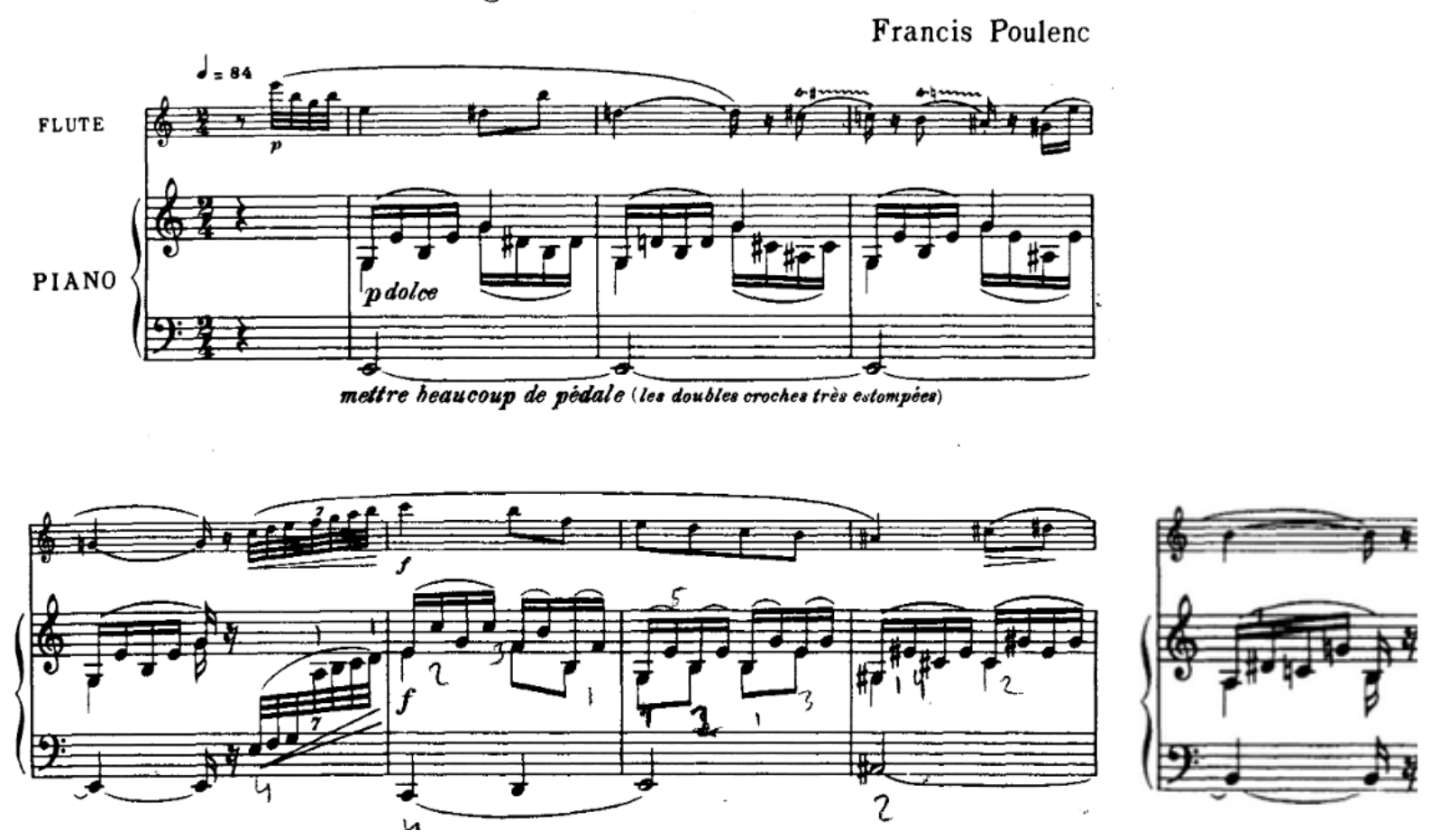

Similarly, Poulenc takes the closed eight bar phrasing structure of the flute opening and reuses it in the clarinet sonata at reh. 2 (Fig. 3). The melody is transformed with the original 16th notes changing to dotted eighth 16th figures, creating a more lyrically optimized line. The presence of the 32 nd note quintuplet in the second bar acts as a rhythmic device to drop the 
octave, resulting in a closed four bar phrase ending on the $\mathrm{C}$ downbeat. Poulenc quotes the next four bars almost entirely from the flute sonata where the weak 32nd note figure is present again and the quarter note melody is augmented from the flute sonata's eighth notes. The melodies are repeated immediately in all three works with the piano up an octave, whereas the winds start on their principal notes and then the melodies expand registerally.

Fig. 3 - Poulenc, Clarinet Sonata, Mvt. I, reh. 2-3
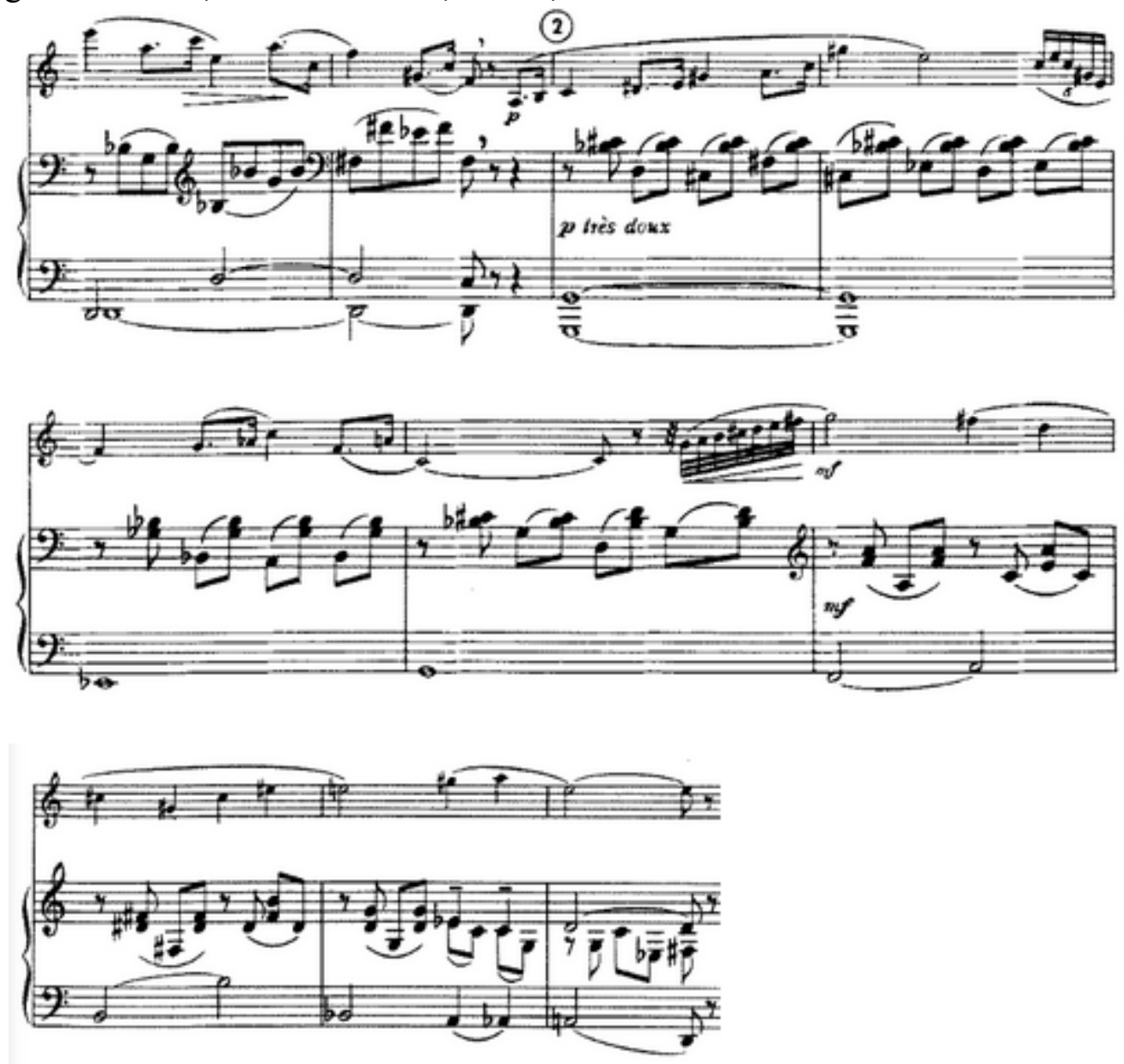

The clarinet melody at reh. 2 comes directly from La voix humaine (1958), Poulenc's one act opera for soprano and orchestra (Fig. 4). In the flute sonata, he quotes himself again and takes a direct melody from his other opera Dialogues de Carmélites (1953) and places it in the flute part of the second movement (Fig. 5 and 6). 
Fig. 4 - Poulenc, La voix humaine, reh. 107-108 (near the ending)
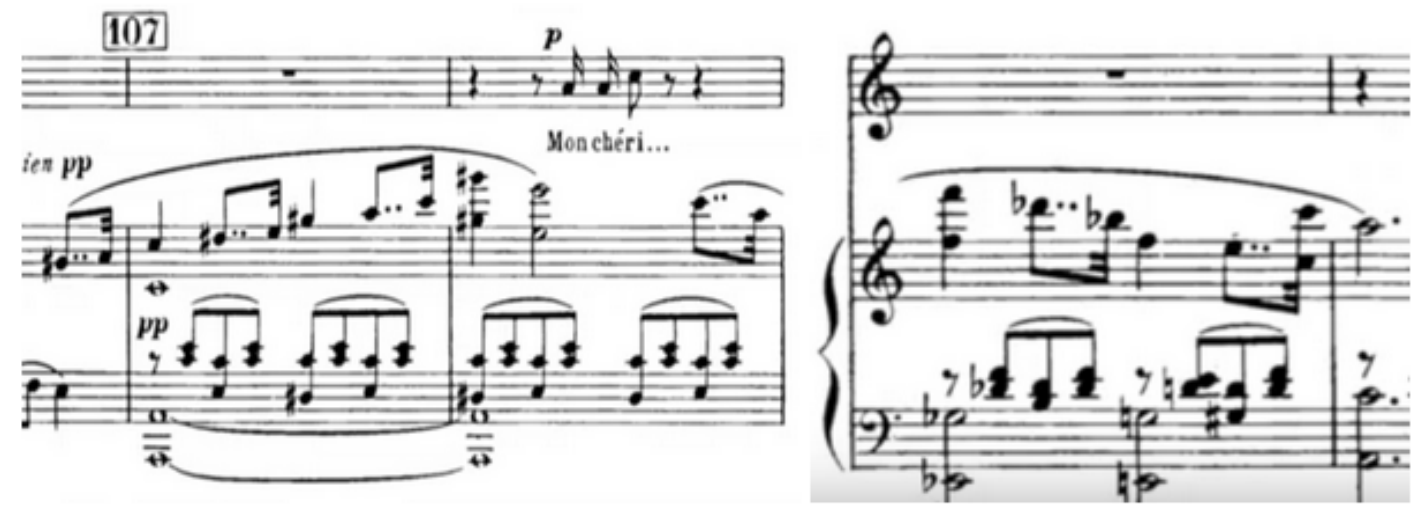

Fig. 5 - Poulenc, Flute Sonata, Mvt. II, pickup to 4 before reh. 1
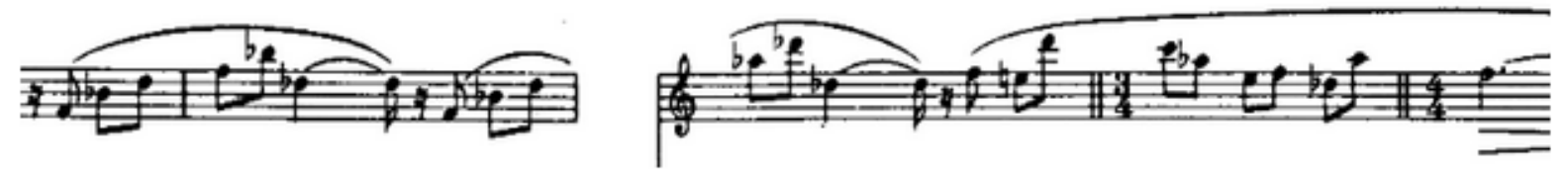

Fig. 6 - Poulenc, Dialogues de Carmélites, act III, scene iii, pickup to 4 before reh. 39

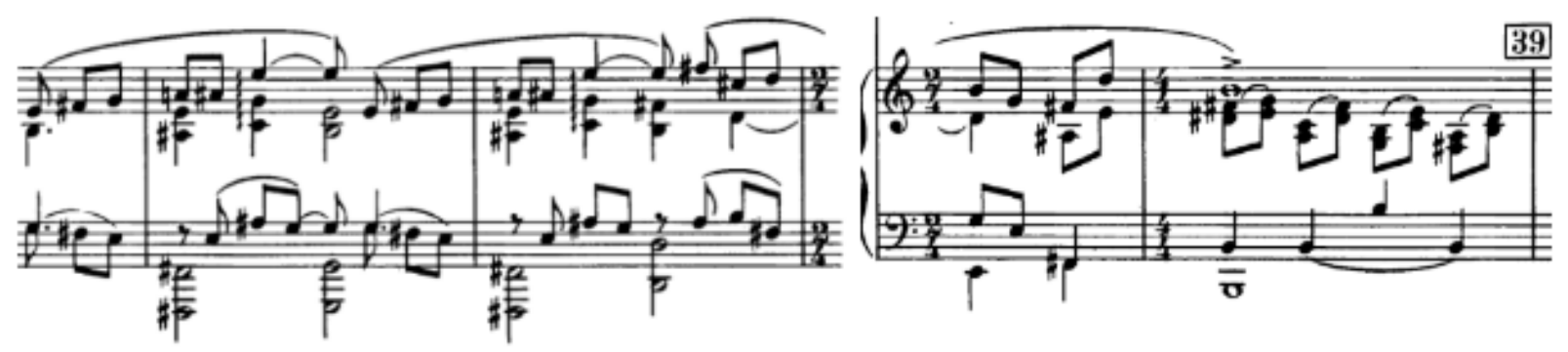

Daniel brings attention to the use of 32nd fragments (Fig. 7 and 8 ) as it is a prominent figure found littered throughout the flute sonata. This figure appears only once in the clarinet sonata at the end of the Romanza. 
Fig. 7 - Poulenc, Flute Sonata, Mvt. I, opening

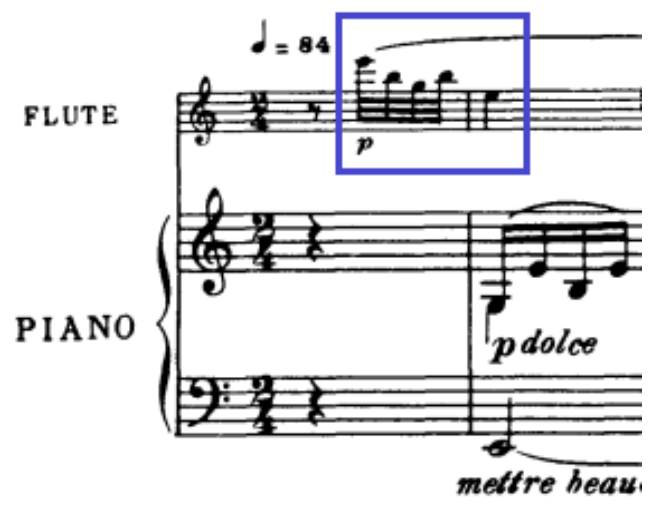

Fig. 8 - Poulenc, Clarinet Sonata, Mvt. II, ending

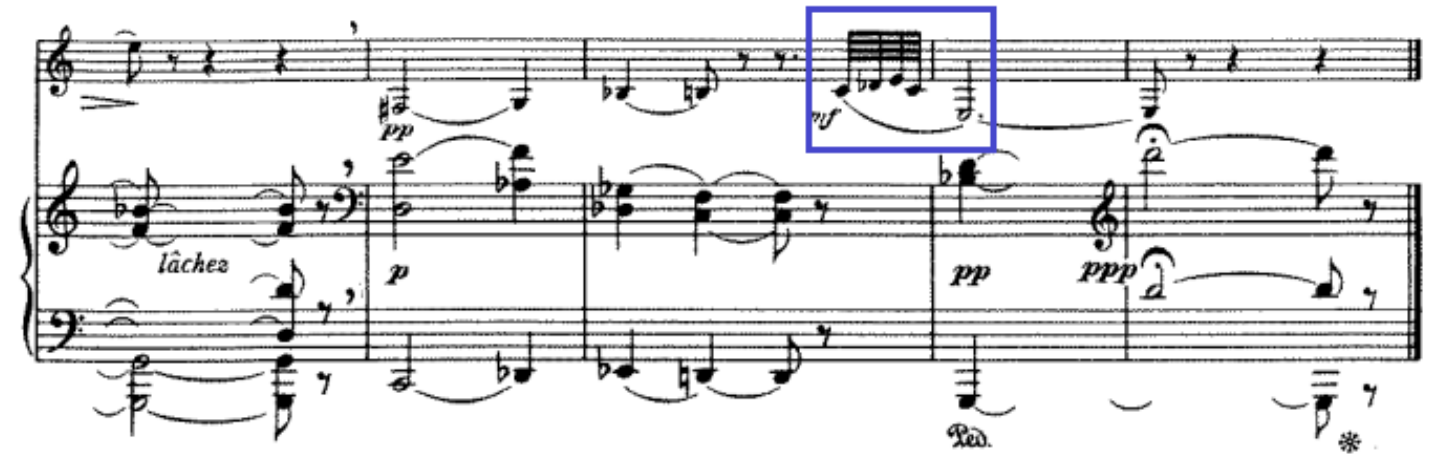

This may have been inspired by Prokofiev's fourth piano sonata where the opening 16th note figure (Fig. 9) is a Beethovian cell in which a figure is taken and developed extensively. While other similar rhythmic values appear in the works, usually as double-dotted figures, the identity of the cell remains the same - a group of four 32nd notes that drop by a fifth or more on the last note (Fig. 10). Poulenc uses this cell as a way to imply the tonal ambiguity of the movement via pitch alteration (Fig. 11). 
Fig. 9 - Prokofiev, Piano Sonata No. 4, Mvt. I, opening

\section{Allegro, molt}

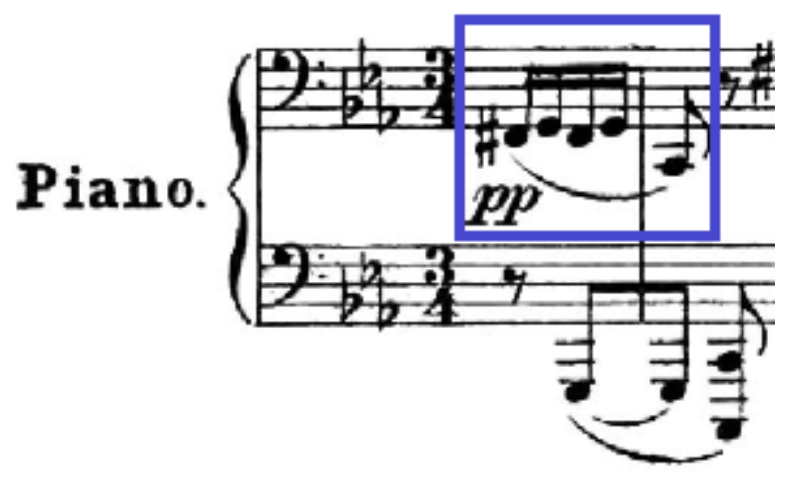

Fig. 10 - Poulenc, Flute Sonata, Mvt. I, 3 bars before reh. 2 (piano part)

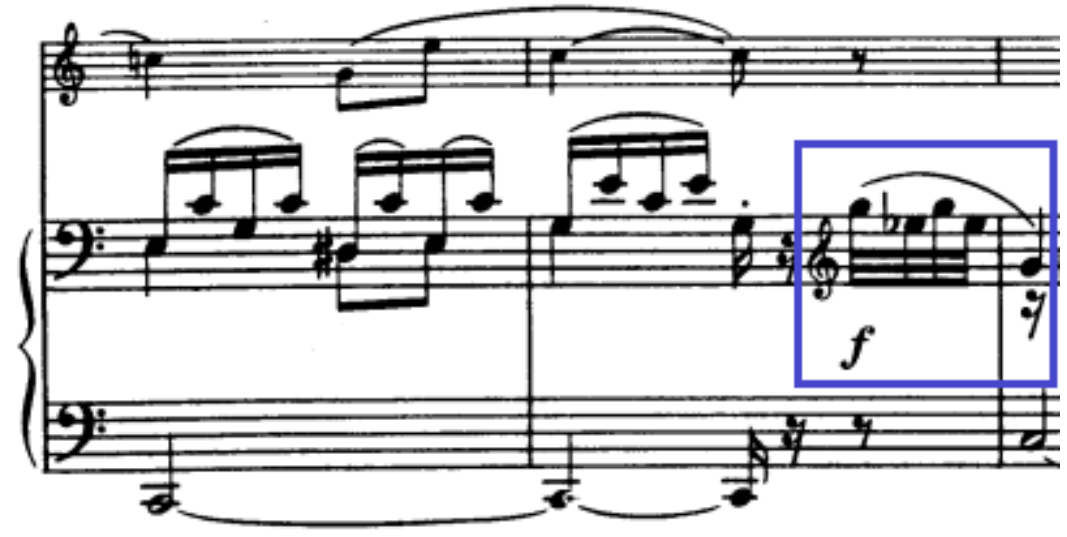

Fig. 11 - Poulenc, Flute Sonata, Mvt. I, ending

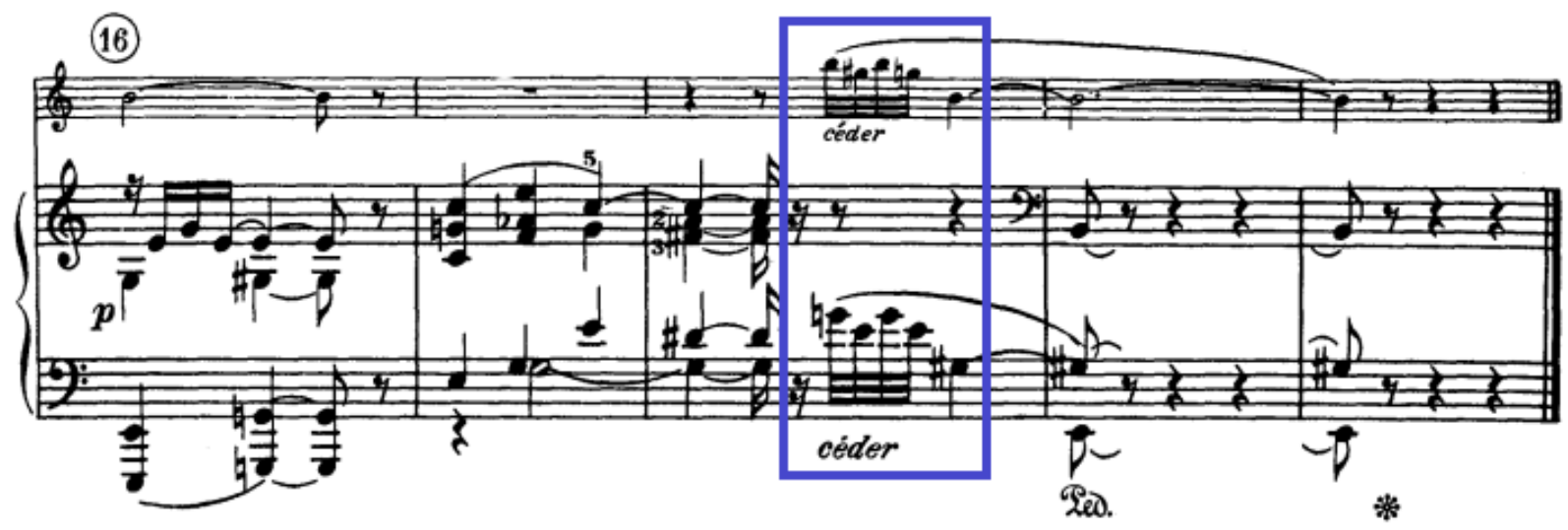


The cell is further evidenced when it returns in the last movement of the flute sonata 2 bars after reh. 9 (Fig. 12).

Fig. 12 - Poulenc, Flute Sonata, Mvt. III, pickup to reh. 9 and 2 bars after reh. 9

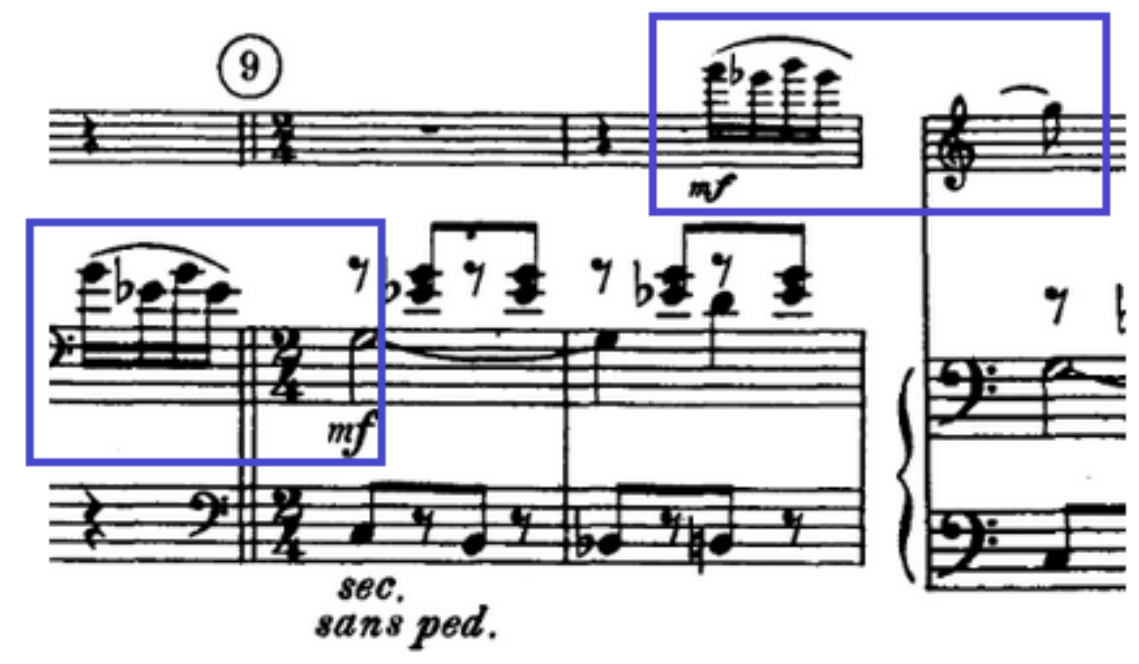

The slight pitch alterations within the cell also confirm Poulin's observation regarding Poulenc's earlier experimental style with structure. The flute and clarinet sonatas share many other thematic elements and, as Daniel rightly said, "rarely has a composer in this century unblushingly used so many common motives in two of his works." 229 Another "Prokofievien" influence can be found in the beginning of the last movement of the clarinet sonata (Fig. 13). It shares a similar "mood and spirit" with the last movement of Prokofiev's fourth piano sonata (Fig. 14).

${ }^{229}$ Daniel, 248. 
Fig. 13 - Poulenc, Clarinet Sonata, Mvt. III, opening

\section{ALLEGRO CON FUOCO}
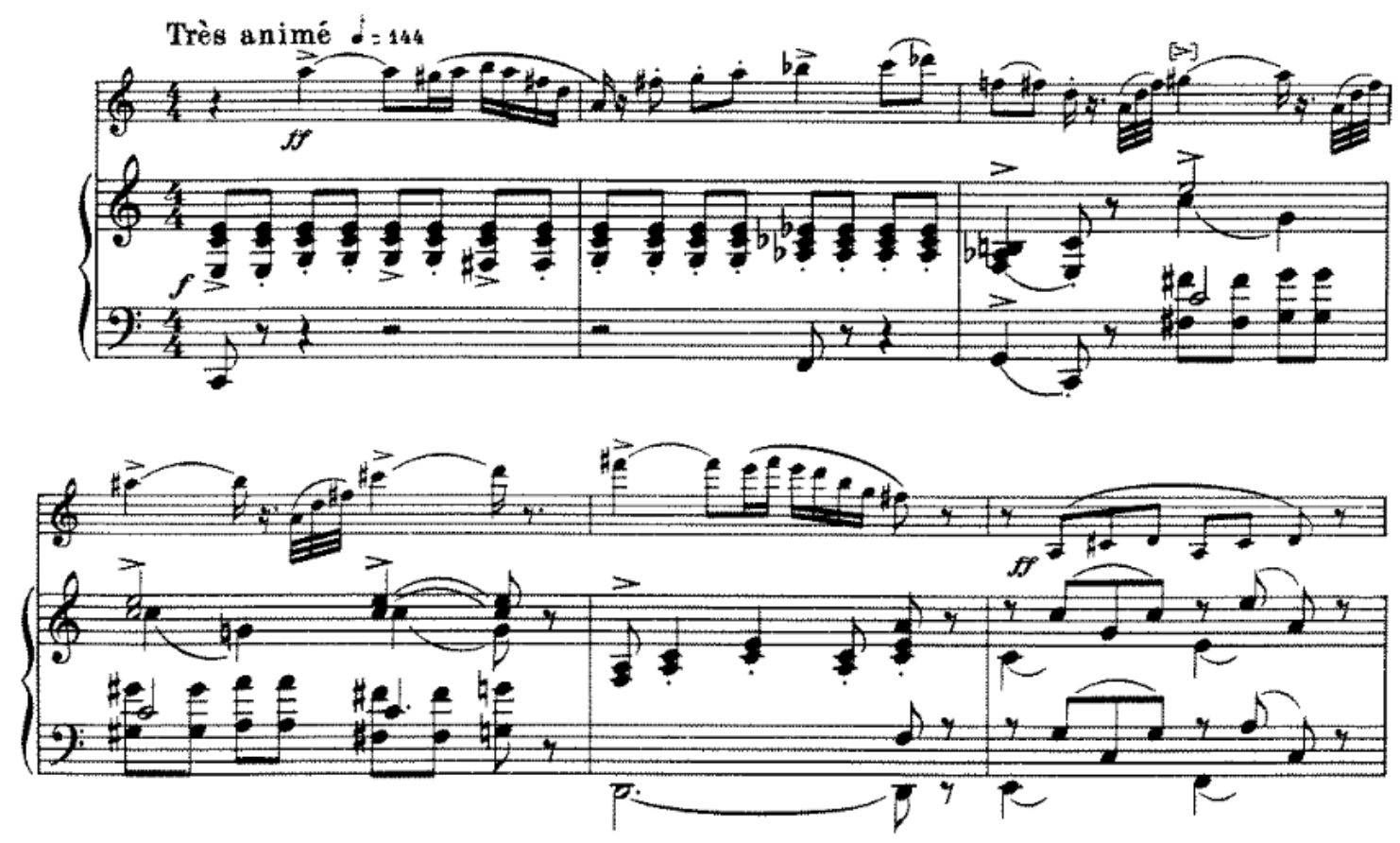

Fig. 14 - Prokofiev, Piano Sonata No.4, Mvt. III, opening

III.

Allegro con brio, ma non leggiere.
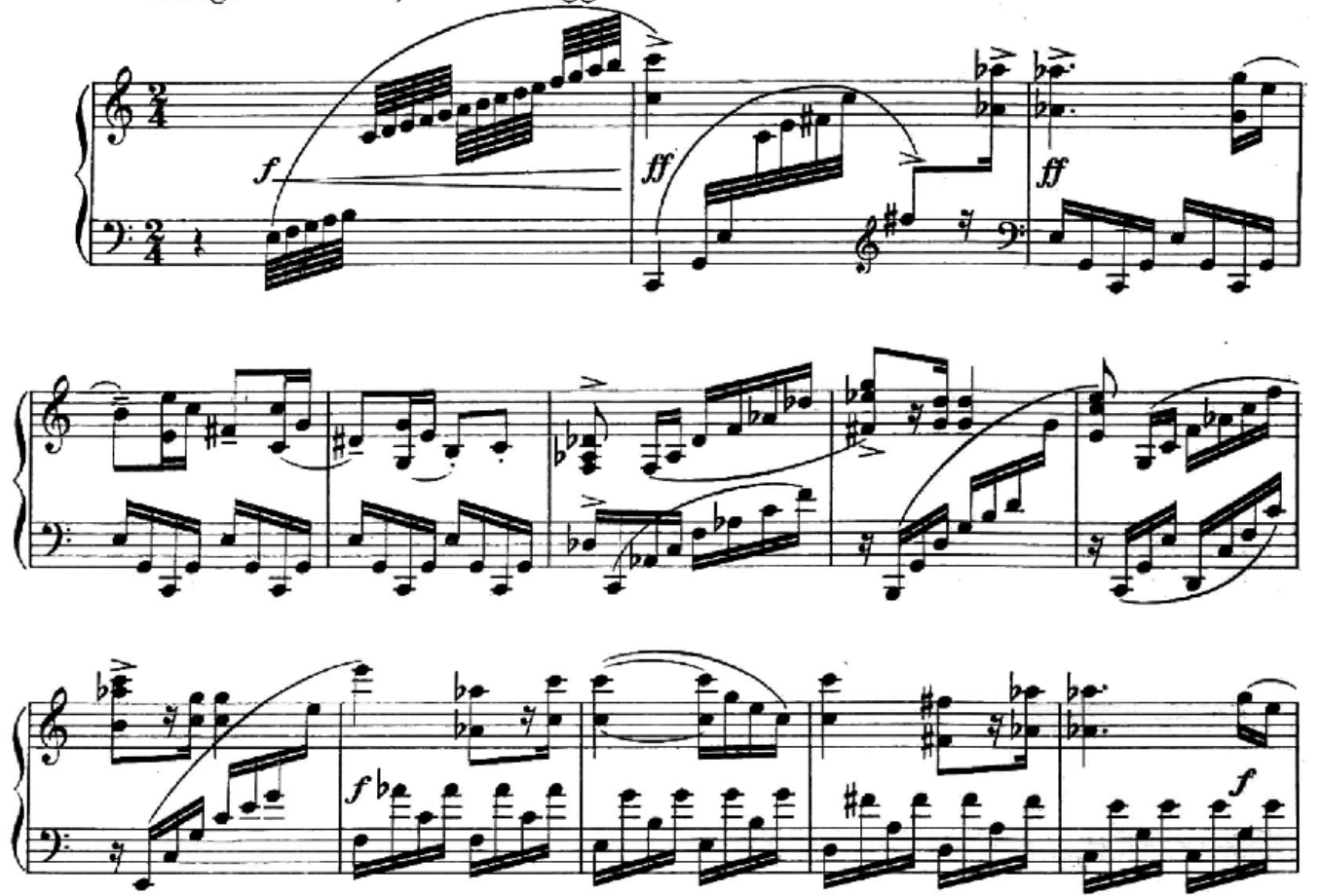
Mm. 3-5 of the clarinet sonata resemble mm. 6-11 of the piano sonata. The clarinet part deviates from there onward, following the flute sonata more closely. Poulin provides an exhaustive chart of all of the self-quoted material in the three wind sonatas (Fig. 15). Daniel and Grant both discuss these similarities but never realize such a chart, making this an invaluable visual aid.

Poulin also mentions the widespread use of fragmentation and sequential transformation in the wind sonatas. ${ }^{230}$ She says what is "missing are the dramatic changes of tempo, style, texture and meter (preceded by silence) of the earlier works. This may be due, in part, to the neoclassical character of [the works]. ${ }^{, 231}$ Poulin may have been referring to Poulenc's Sonata for Two Clarinets (1918) which exemplifies that experimental style.

${ }^{230}$ Poulin, 107.

${ }^{231}$ Ibid., 93. 
Fig. 15 - Poulin, "Self-Quotation In The Sonata For Oboe And Piano, example 2-30" 232

EXAMPLE 2-30

SELF-QUOTATION IN THE SONATA

FOR OBOE AND PIANO

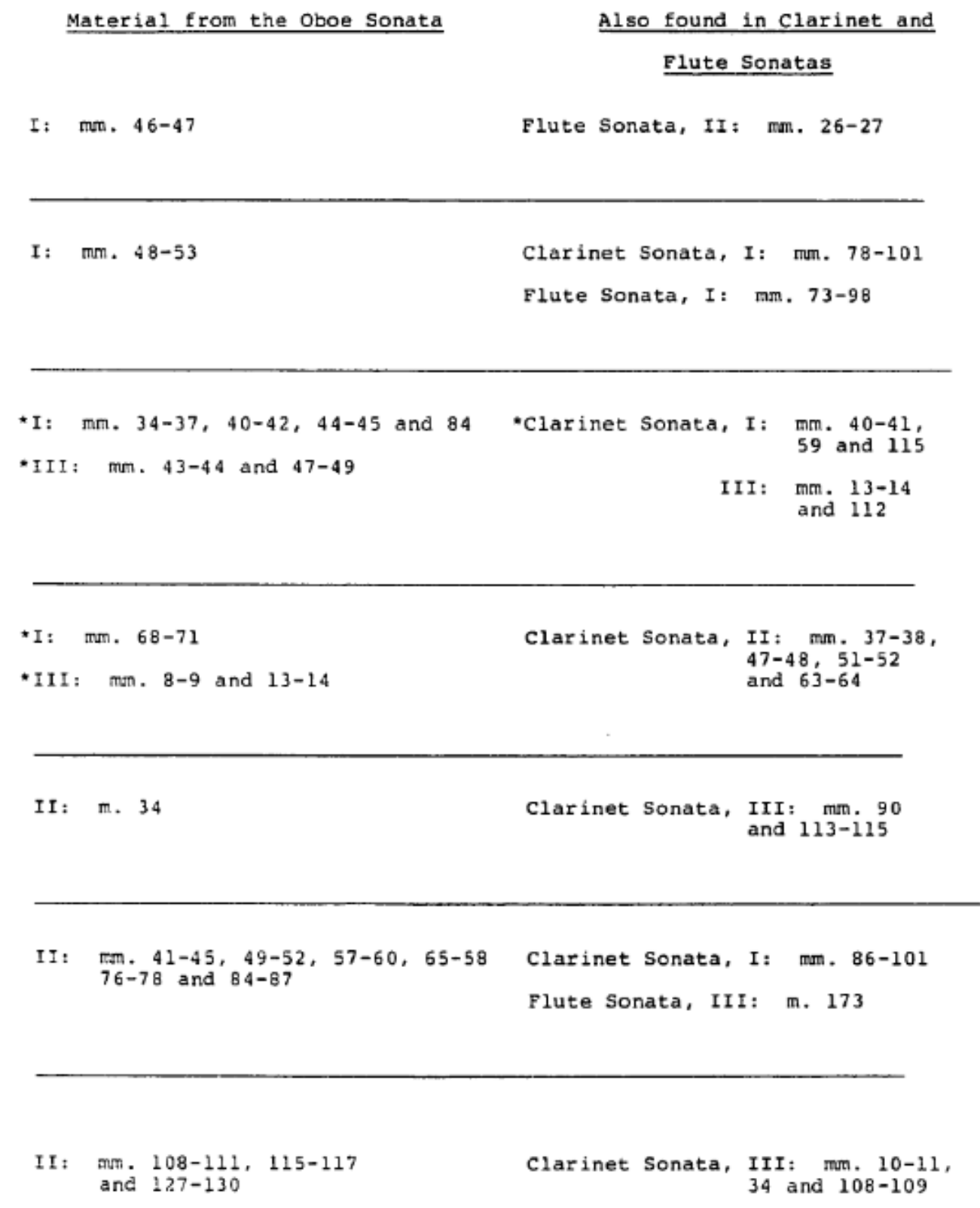

${ }^{232}$ Poulin, 117. 
Where do Les Six play into these sonatas? Prokofiev and members of Les Six were of similar age, often displaying the common aesthetic principles contextualized by Trickey. Musical examples comparing works of Les Six to the oboe sonata prove futile, just as Milhaud and Poulenc firmly believed none of their compositions shared any commonalities. Investigating their works to arbitrarily determine an association to the sonata would be like saying that if apples and oranges both grow on trees, then they must be of the same stock - this is in fact true that they are fruit, but chemically, visually, and objectively they are different. However, it does stand to reason that the unifying contextual aesthetics are present in the conception and handling of thematic material. Poulenc described these works as "san complexes," indicating a simpler compositional style like that of his early period, even referring to the flute sonata as "Debussyan," further suggesting a return to youthfulness. The existence of Beethovien cell fragments found in the flute and clarinet sonatas also confirms this glance back. Daniel agrees that "in [them] can be found elements of his mature style (graceful lyricism, religiosity, a full harmonic vocabulary emphasizing seventh and ninth chords), as well as reminiscences... of his lighthearted, impertinent first period works and his sentimental, romantic works, of the 1940s." ${ }^{233}$ Ciulla agrees that his early period displayed an "affinity for clarity and simplicity [and] is evident in his utilization of traditional formal structures"234 akin to Mozart and Haydn. The spirit of independence can be seen in the overuse of self-quotation without need for originality. Both Daniel and Poulin identify these areas, and Daniel even remarks how it could be that one composer could so unabashedly take from himself without fear of consequence. Finally, Poulenc was aware that "he was of his time" because he knew he had to move away from writing vocal works. He often questioned his current mental and physical state to determine his

\footnotetext{
${ }^{233}$ Daniel, 254.

${ }^{234}$ Ciulla, 10.
} 
compositional direction. After examining the wind sonatas, Poulenc's mature neoclassical style becomes more transparent-it is a homogenization of his experimental, modernist, and populist styles with a Les Six twist that evokes an air of nostalgia seldom heard today.

\section{Élégie}

In the analyses, each researcher gives an overview of the form; Daniel and Poulin offer a traditional approach and Grant a visual one. They all mention that the sonata's form deviates from the typical F-S-F expectation and is instead S-F-S. The dedication is responsible for this, imposing an extramusical element on the form. From there, both Daniel and Poulin dive into the first movement and notice the use of a "ternary plan," ${ }^{235} \mathrm{ABA}$, primarily divided up by major rehearsal sections: the beginning to reh. 6, 6-9, and 9 to the ending. Grant is the only one who notices that the opening oboe monologue flirts with $\mathrm{g}$ minor, foreshadowing the ambiguity of the movement's tonal center (Fig. 16). Another detail they all miss is the self-quotation from the beginning of the second movement of the clarinet sonata in the opening oboe line (Fig. 17). Both instruments are completely solo, further indicating tonal ambiguity but also establishing a central mood that is deeply intimate. Like the oboe sonata, the clarinet sonata is also dedicated (to Honegger), further confirming the presence of thematic planning stemming from extramusical ideas.

${ }^{235}$ Daniel, 251. 
Fig. 16 - Poulenc, Oboe Sonata, Mvt. I, opening

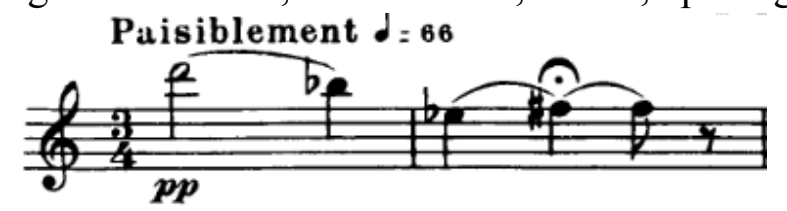

Fig. 17 - Poulenc, Clarinet Sonata, Mvt. II, opening

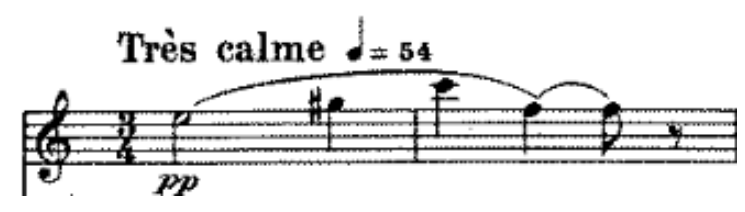

Unlike Daniel and Poulin, Grant organizes the work by phrase groupings while avoiding traditional theory. She identifies two larger sections, mm. 1-21 and mm. 22-47, and refers to them roughly as an "exposition" and "development." She goes deeper and arranges the larger sections into sub-groupings-Section 1 [mm. 1-2, 3-10, 11-16, and 17-21] and Section 2 [mm. 22-29, 30-33, and 34-47].

Both Daniel and Grant agree where the B section begins, but Poulin does not. In Poulin's chart (Fig. 18) she lists B as starting at reh. 4 and lasting for thirty-eight measures, which is reh. 9. Daniel lists B as beginning at reh. 6 and ending at reh. 9. While they both agree on the ending, I think Daniel is more right in his observations because the section at reh. 6 is different enough in both style and "mood and spirit."

Fig. 18 - Poulin, "Form Of The Sonata For Oboe And Piano, figure 2-9"236

I. Elégie

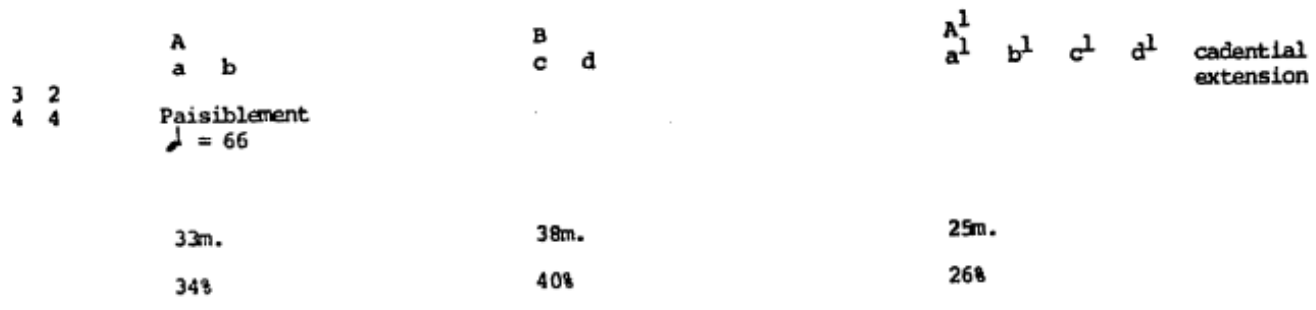

${ }^{236}$ Poulin, 115. 
Poulin may have grouped there because it uses the dotted populist style (Fig. 19), which was absent in the movement until then. This area does not follow the cited "mood and spirit" of reh. 6, and the feeling is too similar to the A section for it to be possibly grouped with B. At reh. 6, the dotted rhythm returns but undergoes a 64th note transformation (Fig. 20). This section is another major self-quotation that comes from the first movement of the clarinet sonata (Fig. 21).

Fig. 19 - Poulenc, Oboe Sonata, Mvt. I, reh. 4

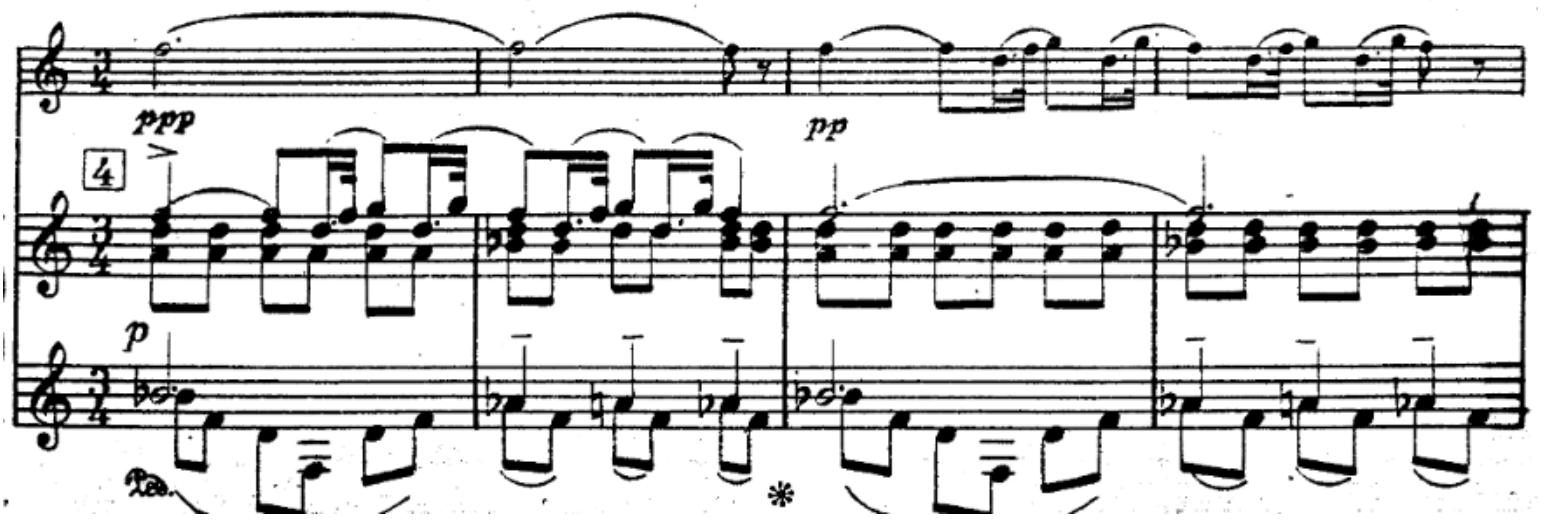

Fig. 20 - Poulenc, Oboe Sonata, Mvt. I, reh. 6
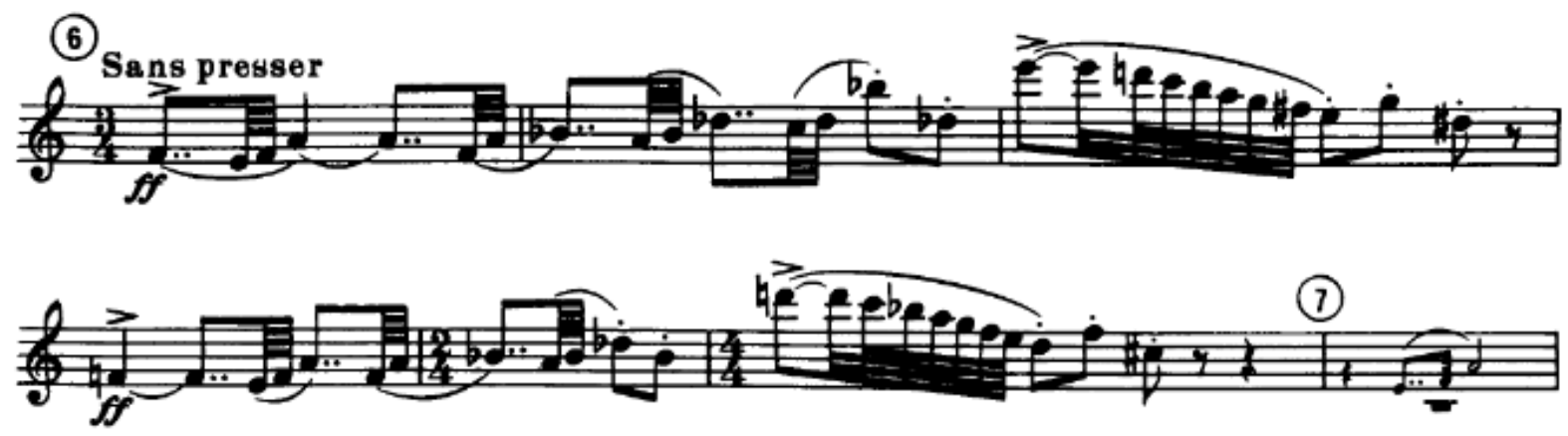

Fig. 21 - Poulenc, Clarinet Sonata, Mvt. I, reh. 8

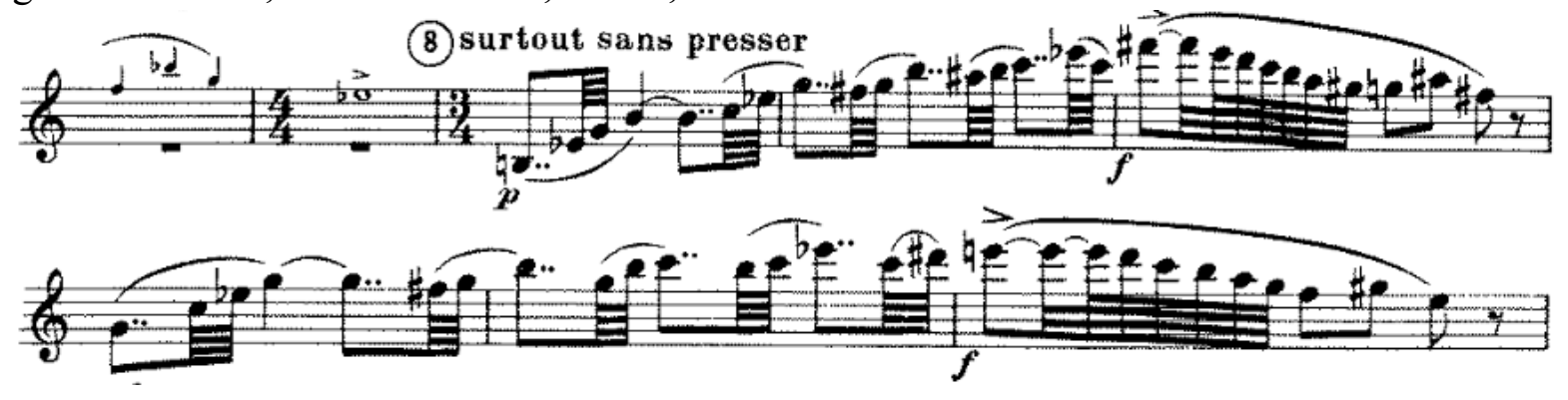


Grant deviates from Daniel and Poulin as to where the ending of the B section is. Instead, she shortens it from reh. 6-8, leaving mm. 64-71 as a transition to the anticipated "return" of A. Before that though, Grant makes a marvelous connection between the four accented notes in the oboe melody (blocked) at reh. 6 to the liturgical Dies irae (Fig. 22 and 23). She says:

Poulenc gives a concrete clue to musical significance by placing accent marks over the four notes that mark the registral extremes of the oboe part: [F4-E6-F4-D6]. Although the four notes are separated physically both by musical space and by registration, they spell out the first four notes of the Dies irae (the Sequence found in the Requiem Mass) in the Catholic liturgy. This is not a coincidence. The accented notes mark registral extremes and are the only accented notes in the section. ${ }^{237}$

Fig. 22 - Liturgical chant, Dies irae 238

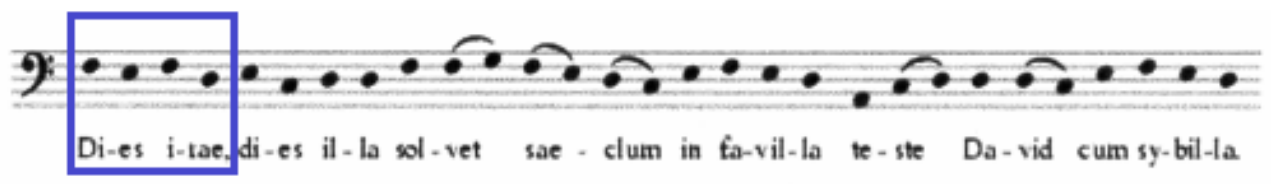

Fig. 23 - Poulenc, Oboe Sonata, Mvt. I, reh. 6, Dies irae notes

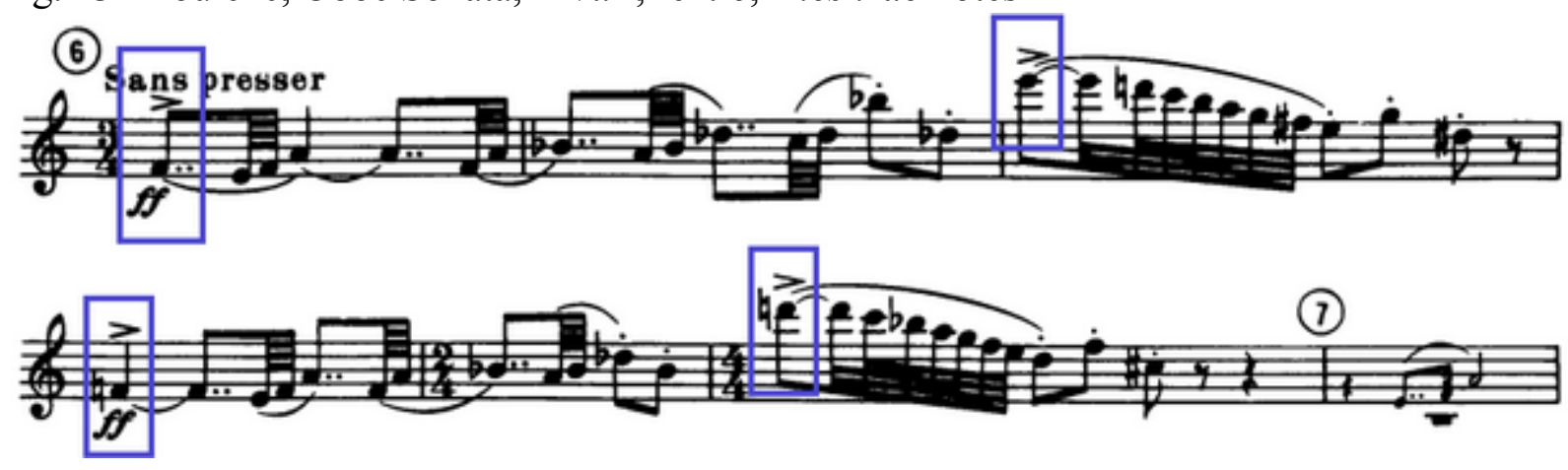

Ciulla also suggests this was a common technique of Poulenc's, where articulation is used as a thematic tool. ${ }^{239}$ I agree with Grant on the transitory nature of the material from mm. 64-71, as it is not seen anywhere else in the movement.

\footnotetext{
${ }^{237}$ Grant, 90.

${ }^{238}$ Grove Music Online, s.v. "Dies irae," accessed November 6th, 2021, https://doi-org.wvu.idm.oclc.org/10.1093/gmo/9781561592630.article.40040. ${ }^{239}$ Ciulla, 18.
} 
Another self-quotation appears from the second and third movements of the clarinet sonata in this transitory section (Fig. 24 and 25). It first appears at the beginning of the Romanza and then again augmented and extended in the Allegro con Fuoco.

Fig. 24 - Poulenc, Oboe Sonata, Mvt. I, 2 bars after reh. 8

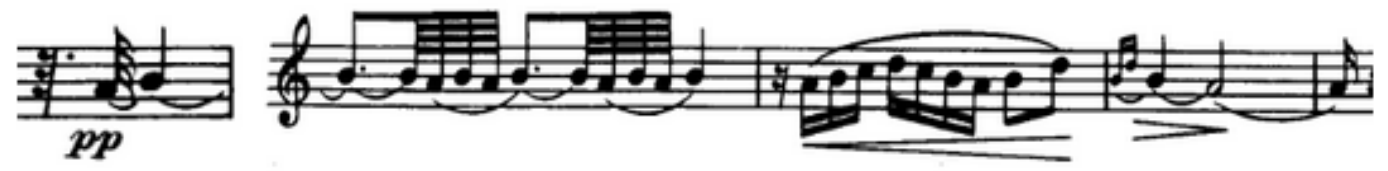

Fig. 25 - Poulenc, Clarinet Sonata, Mvt. II, 3 bars after opening

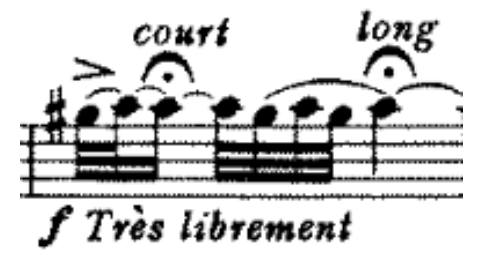

Fig. 26 - Poulenc, Clarinet Sonata, Mvt. III, 2 bars after reh. 9
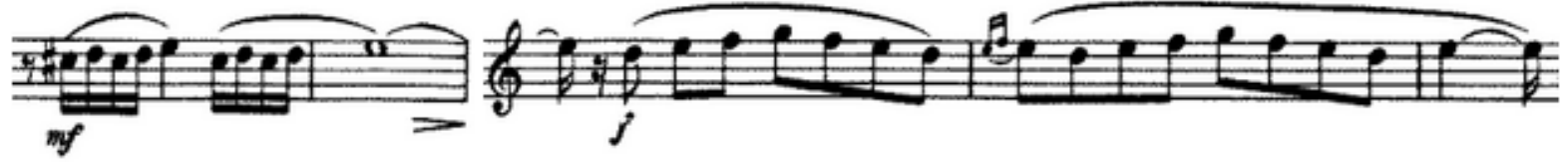

Referring back to Poulin's chart, the final A1 section is represented well. After reviewing the analyses, I've made some alterations to her chart (Fig. 27): I shifted "c" from the B section to the A section, added "+ transition" in the B section, and added "c2" before the cadential extension in A1.

Fig. 27 - Poulin, "Form Of The Sonata For Oboe And Piano" revised by Klein

\section{Élégie}

A

$a+b+c$

$(\mathrm{mm} .1-47)$
B

d+transition

(mm. 48-71)
A1

$\mathrm{a} 1+\mathrm{b} 1+\mathrm{c} 1+\mathrm{d} 1+\mathrm{c} 2+$ cadential extension

(mm. 72-end) 
Grant would agree since she also noticed that "everything begins to become more and more fragmented and broken apart." 240 The movement ends similarly to how it began with the oboe whispering a $\mathrm{D}$ while the piano reaffirms the tonal ambiguity of $\mathrm{g}$ minor with a raised seventh and eleventh in either hand (Fig. 28).

Fig. 28 - Poulenc, Oboe Sonata, Mvt. I, ending

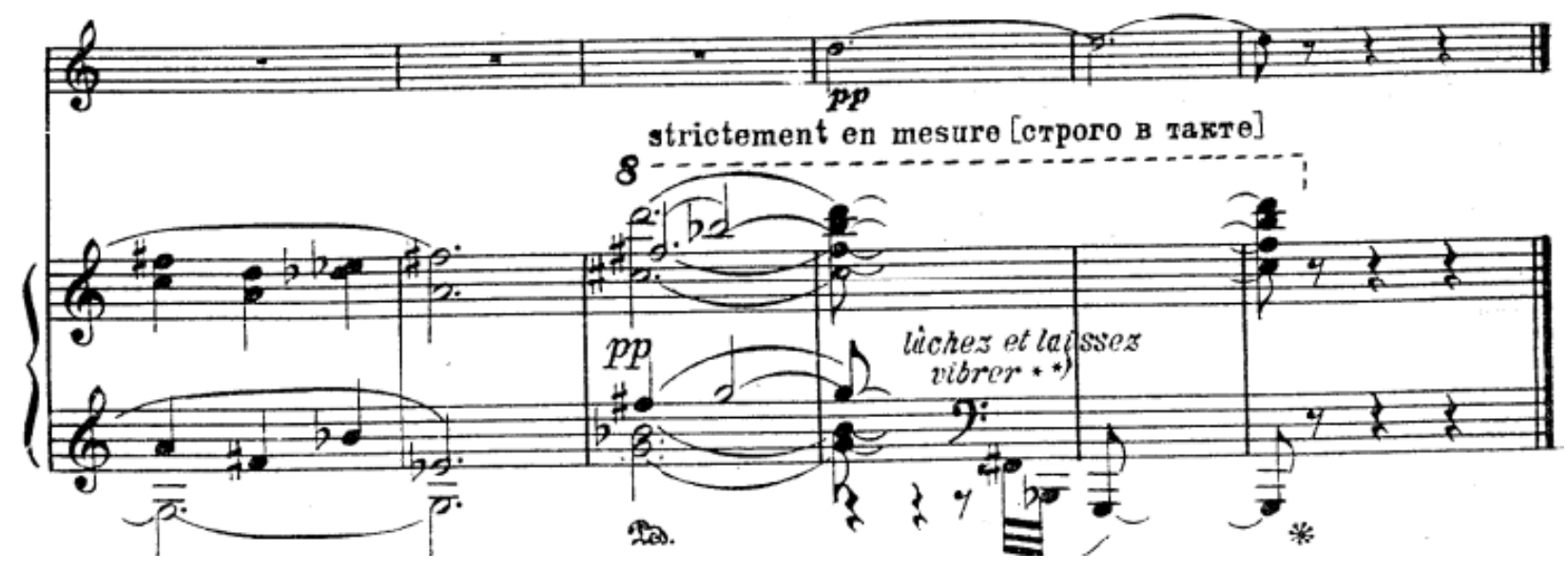

Scherzo

Like in the first movement, ternary form returns on an almost "Dvorakien" scale. The form is a large rondo juxtaposed against a slower B section that ends with the return of A. Grant suggests that the B section behaves almost like a trio, "but this is no trio. Poulenc has stepped way out of bounds." ${ }^{241}$ Extramusical ideas are present in the Scherzo, again drawing inspiration from the dedication. Daniel and Poulin both provide formal charts of this movement, adding rehearsal numbers and tonal areas when observed (Fig. 29 and 30).

\footnotetext{
${ }^{240}$ Grant, 93.
}

${ }^{241}$ Ibid., 78. 
Fig. 29 - Daniel, rondo ABA ternary form chart ${ }^{242}$

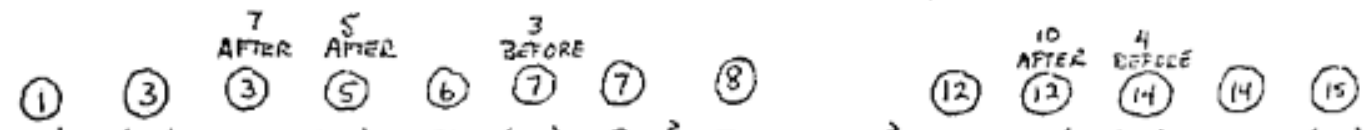

$$
\begin{aligned}
& A, A^{\prime}(A) B(A) B(A) C \xi D \text { (silw) } \xi A A^{\prime}(A) C \text { (A) } \\
& B b \quad G b \quad B b m . E b \quad G m . B b \quad I F b b=B b \quad G b \quad B b
\end{aligned}
$$

Fig. 30 - Poulin, "Form Of The Sonata For Oboe And Piano, figure 2-9"243

II. Scherzo

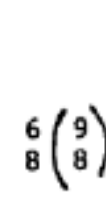

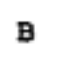

432

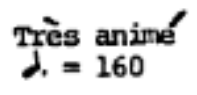

$100 \mathrm{~m}$.

538

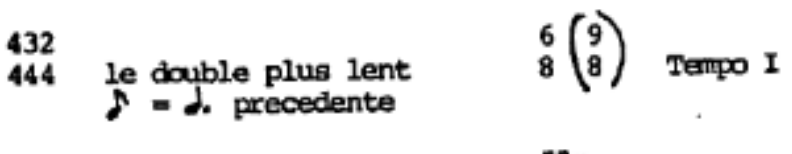

$34 m$.

188

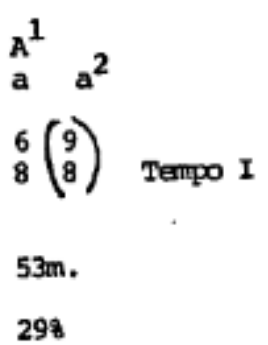

298

Poulin is not convinced that the Scherzo is a rondo. Instead, she insists that it takes on the character of a classical rondo, but "were it not for the extended B section (in the Popular stylistic trait), this movement could be classified as a rondo." ${ }^{244}$ I do not agree with Poulin because Daniel's presentation is the most complete version of the form while managing to include its fragmented complexity. It is missing the larger ABA ternary denotations, however, so I have added those to his chart to better display the full form (Fig. 31). In his chart, he explains further that "(a) represents a shortened reprise or a suggestion of "a."

\footnotetext{
${ }^{242}$ Daniel, 251.

${ }^{243}$ Poulin, 115.

${ }^{244}$ Ibid., 114.

${ }^{245}$ Daniel, 252.
} 
Fig. 31 - Daniel, "rondo ABA ternary form chart" revised by Klein

\section{Scherzo}

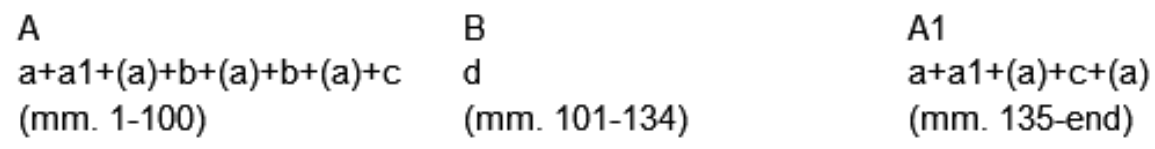

Another prominent self-quote appears with the "b" figure in section A. It comes from the slower Très calme section at reh. 9 of the clarinet sonata (Fig. 32), indicating that it should be more lyrically driven. In the Scherzo, the figure is first used seven bars after reh. 3 (Fig. 33) and several times later, but in the most virtuosic way at reh. 6. This figure may have been inspired by Prokofiev's Romeo and Juliet Suite, No.2 - the famous flute tune from the Moderato tranquillo sounds eerily similar to the clarinet sonata, even sharing the same tempo marking, quarter=54 (Fig. 34). In all three examples, the winds ascend an octave and return to the principal note creating this haunting cyclic melody (the figure is unique to the oboe and clarinet sonatas).

Fig. 32 - Poulenc, Clarinet Sonata, Mvt. I, reh. 9

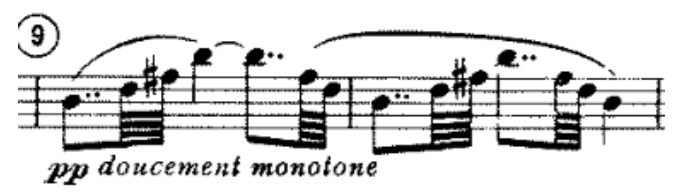

Fig. 33 - Poulenc, Oboe Sonata, Mvt. II, 7 bars after reh. 3

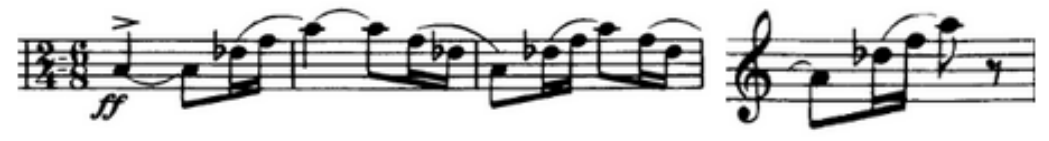

Fig. 34 - Prokofiev, Romeo and Juliet Suite No. 2, Mvt. I, reh. 7

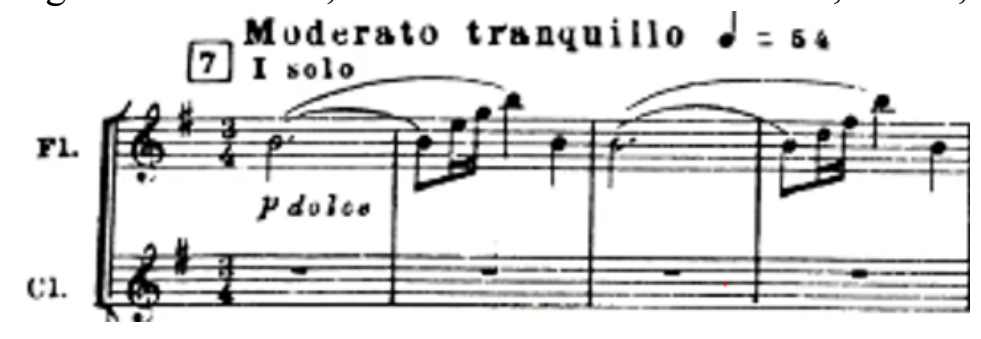


The B section that starts at le double plus lent (Fig. 35) is a striking juxtaposition to the virtuosity of the A section. Grant offers a visual account:

[The] three measure transition transports the listener from the rollicking A section into a completely different realm. Dissonant harmonic dyads, doubled in each hand, descend from the piano's middle register into the very low range as the dynamics grow ever softer. The dyads form a sequential pattern in which the gradually expanding intervals alternate between consonance and dissonance, their upper and lower notes moving chromatically in contrary motion. ${ }^{246}$

Fig. 35 - Poulenc, Sonata, Mvt. II, reh. 8

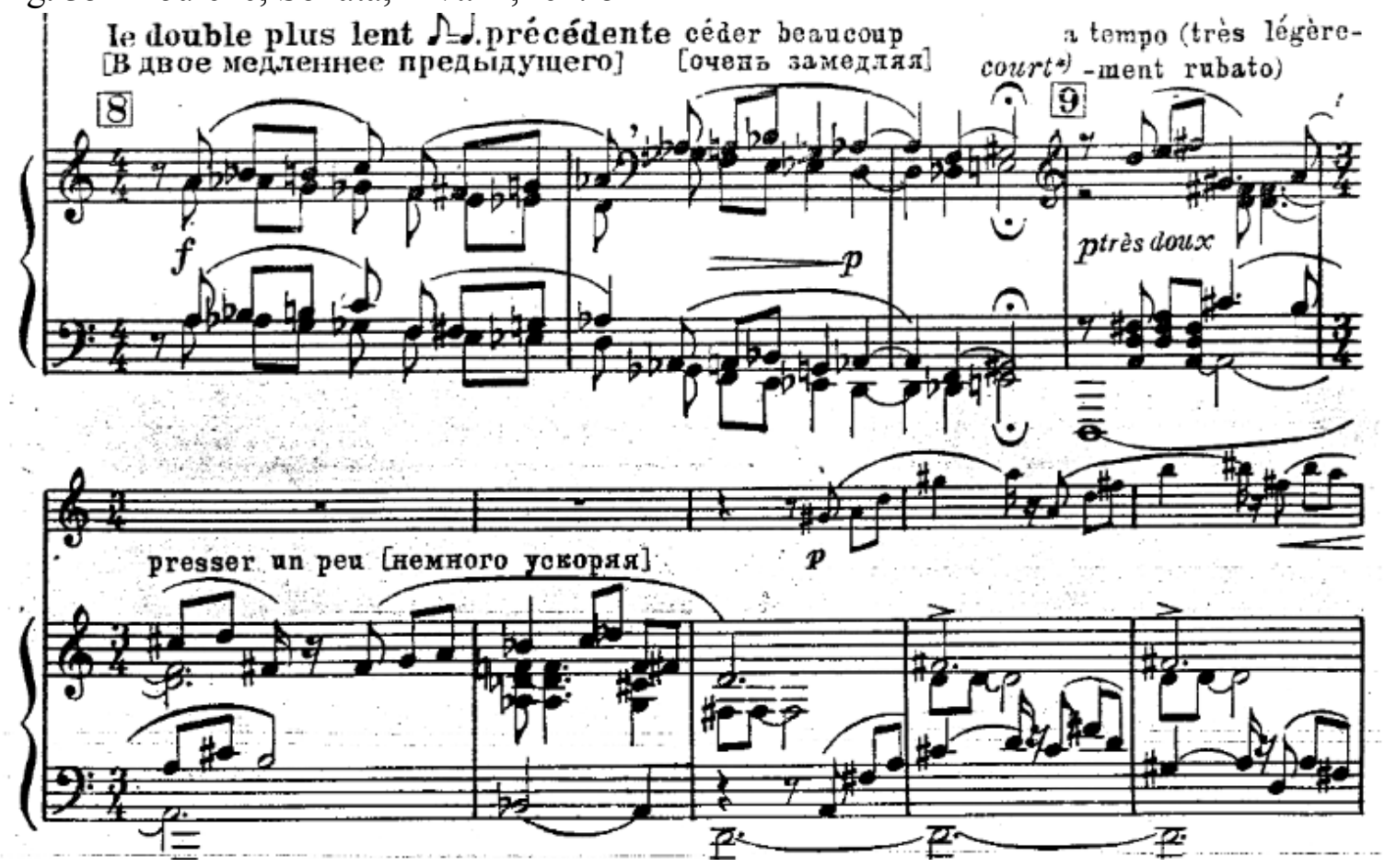

Daniel equally describes this section as having a "Rachmaninoff-like late romantic flavor in its lyricism, fullness, and sentimentality." ${ }^{247}$ Nichols attributes it more properly to Prokofiev, saying that it was "one of his many talents, when he chose to exercise it, was for writing tunes." 248 Daniel may have been unaware of the thematic implications of the dedication, therefore misplacing the influence.

\footnotetext{
${ }^{246}$ Grant, 78.

${ }^{247}$ Daniel, 252.

${ }^{248}$ Nichols, 282.
} 
For the remainder of the movement, Daniel and Poulin provide no further information. Grant lays out more gestural observations by giving descriptive "play-by-plays" of the oboe melodies and piano accompaniment. I argue that Poulenc, being a prolific vocal composer, proposed a song here in which each note of the oboe part could be set to text (Fig. 36).

Fig. 36 - Poulenc, Oboe Sonata, Mvt. II, 4 bars after reh. 9-12
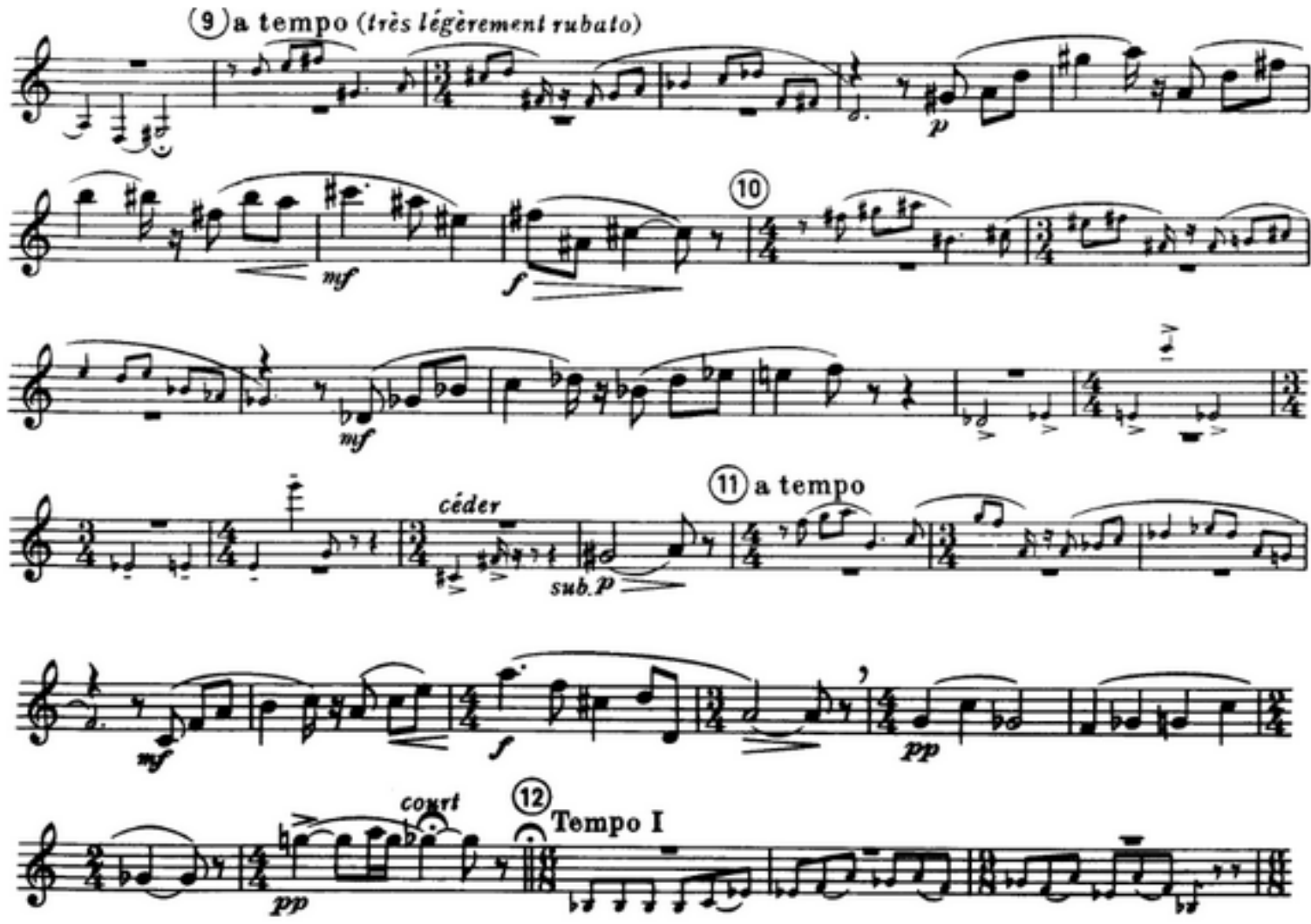

This section is reminiscent of the Cantilena from the flute sonata, heavily suggesting an extramusical song-like quality to it. Whatever it may be, there is no clear reason for this section, and as Grant said, it is definitely not a trio. So what is it? Is it a homage to Prokofiev, a nod to Rachmaninoff, or a song? It poses more questions than it answers.

The return of the A section completes the ternary form and Poulenc does not introduce any new material. Grant brings up the unique question of pedalling at the beginning of the 
movement since the "score indicates neither pedal nor staccato markings." ${ }^{249}$ She suggests that it is up to the pianist as "[they] often perform this section in a detached manner that disguises its harmonic underpinnings. ${ }^{, 250}$ She makes the observation that when the pedal is employed, the piano sounds almost bell-like, thereby creating a more "emotional counterpart to the interiority of the middle section." 251 This conversation on pedalling definitely evokes memories of Viñes.

\section{Déploration}

The final movement of the sonata continues exploring the extramusical themes of the dedication as set to déploration:

Originally, a poem in which the passing of an individual is announced and communities to which the departed belong are called to mourn... In some déplorations, such tributes take the form of emulating the style or mannerisms of the composer deplored. ${ }^{252}$

Daniel provides a starting point of the context of the movement, saying "it's a sort of liturgical chant... [and it] opens in Poulenc's religious style: soft, gentle, chordal. The initial open fifth and the oscillating incomplete seventh and ninth chords are reminiscent of the organ." ${ }^{253}$ Grant adds that "performance instructions [reveal] associations that suggest ${ }^{254}$ both religious references and a physical space: a cathedral. ${ }^{, 255}$ With this description it is easier to visualize a group of monks chanting the first three bars of the piano line then (Fig. 37).

\footnotetext{
${ }^{249}$ Grant, 82.

${ }^{250}$ Ibid.

${ }^{251}$ Ibid.

${ }^{252}$ Grove Music Online, s.v. "Déploration (Fr.)," accessed October 13th, 2021, https://doi-org.wvu.idm.oclc.org/10.1093/omo/9781561592630.013.90000315369.

${ }^{253}$ Daniel, 252.

${ }^{254}$ The original quotation includes the word "not" after "suggest" but it is believed to be an error, as Grant later explains the religious associations of the movement and cathedral setting. ${ }^{255}$ Grant, 96.
} 
Fig. 37 - Poulenc, Oboe Sonata, Mvt. III, opening

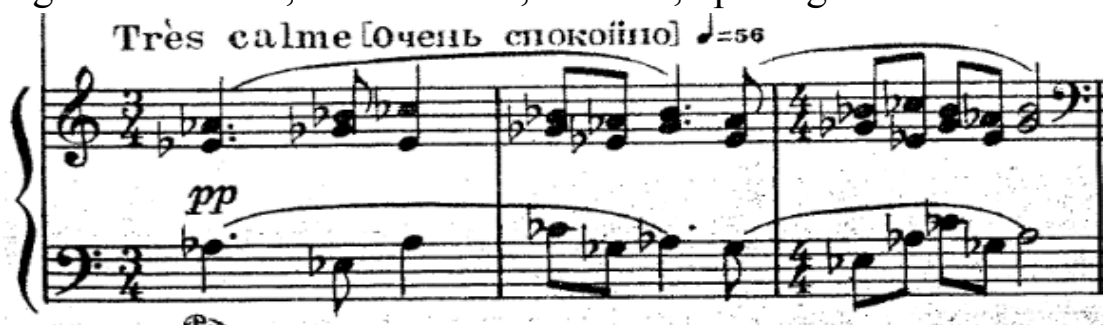

2 20.

Daniel, while pointing to the religious tone of the movement, misplaces the thematic association again. Instead, he believes that Poulenc could have been "accepting his coming death peacefully." ${ }^{256}$ Grant quickly dismisses this idea, saying, "Poulenc died suddenly several months after he composed the oboe sonata; he even had social plans for the day he died." ${ }^{257}$ She properly redirects attention back to Prokofiev. From here, Poulin, Daniel, and Grant all address the tonal area of the movement as a-flat minor, but Poulin is the only one who identifies ABA ternary form (Fig. 38).

Fig. 38 - Poulin, "Form Of The Sonata For Oboe And Piano, figure 2-9"258

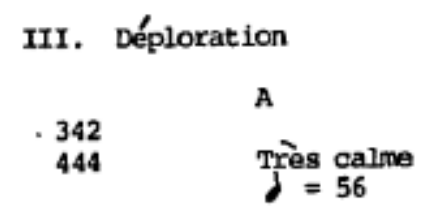

$26 \mathrm{~m}$.

378

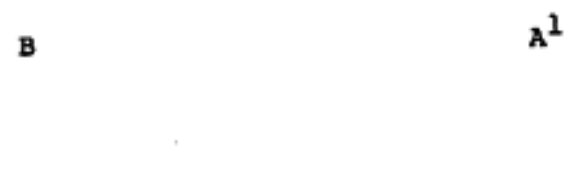

23m.

33워
$\mathbf{A}^{1}$

$20 \mathrm{~m}$.

298

Problems arise when comparing her analysis to the music again. The chart is overly simplified and does not address returning motives from the first movement. These figures are the “+transition" and "c," and I added them to my revision (Fig. 39).

${ }^{566}$ Daniel, 252.

${ }^{257}$ Grant, 95.

${ }^{258}$ Poulin, 115. 
Fig. 39 - Poulin, "Form Of The Sonata For Oboe And Piano" revised by Klein

\section{Déploration}
A
a
(mm. 1-26)
B
(+transition) $+\mathrm{a}+(\mathrm{c})$
(mm. 26-49)
A1
a1+coda
(mm. 50-end)

The transition and the dotted "c" section of the first movement come back in the B section of the last movement (Fig. 40). The transition material is the same figure that was previously identified as coming from the Romanza of the clarinet sonata.

Fig. 40 - Poulenc, Oboe Sonata, Mvt. III, "transition" material and "c" at reh. 6
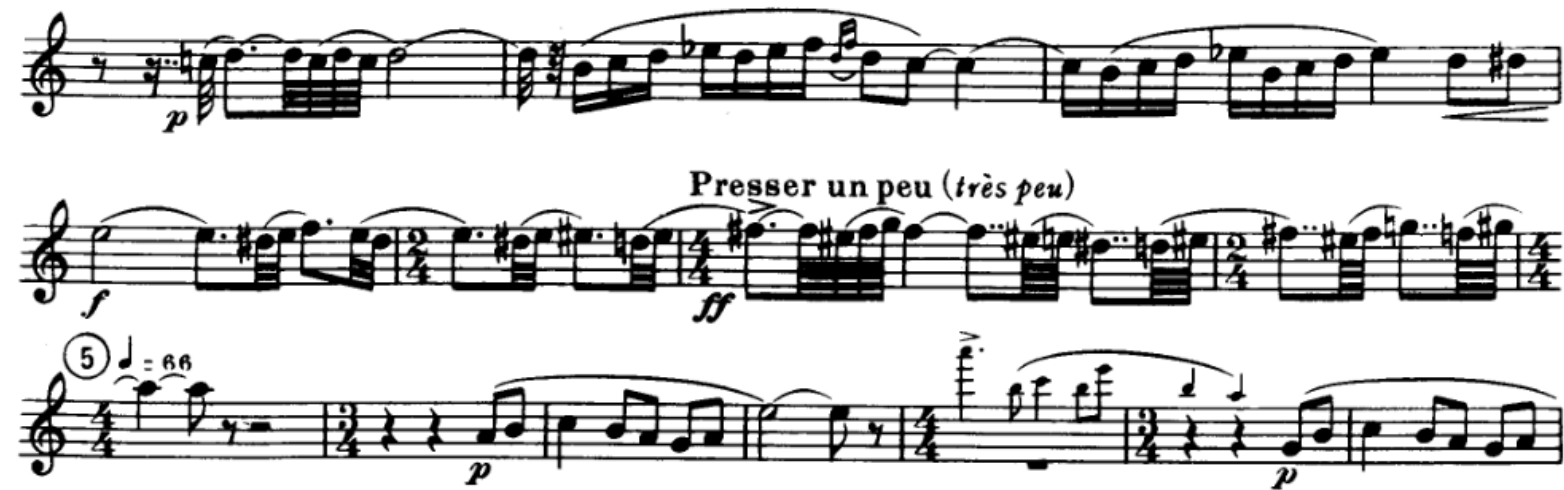

(6)

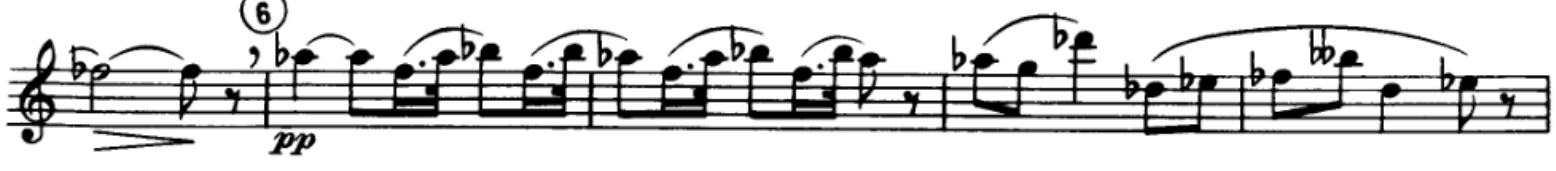

Grant makes another suggestion that the setting of dynamics and register in the oboe part is a vocal feature:

Poulenc paints an instrumental picture of choral singing. The slight melodic variations in many repetitions emulate those that would naturally occur with changing texts sung to the same chant melody in liturgical music. The extremes of the oboe's register impy higher and lower voices, and terraced dynamics imply soloists and choirs answering each other in this emulation of responsorial singing. ${ }^{259}$

${ }^{259}$ Grant, 96-97. 
She refers to rehearsal 1 (Fig. 41) and rehearsal 2 (Fig. 42) as the best figures that exemplify the setting of the "oboe as voice."

Fig. 41 - Poulenc, Oboe Sonata, Mvt. III, reh. 1

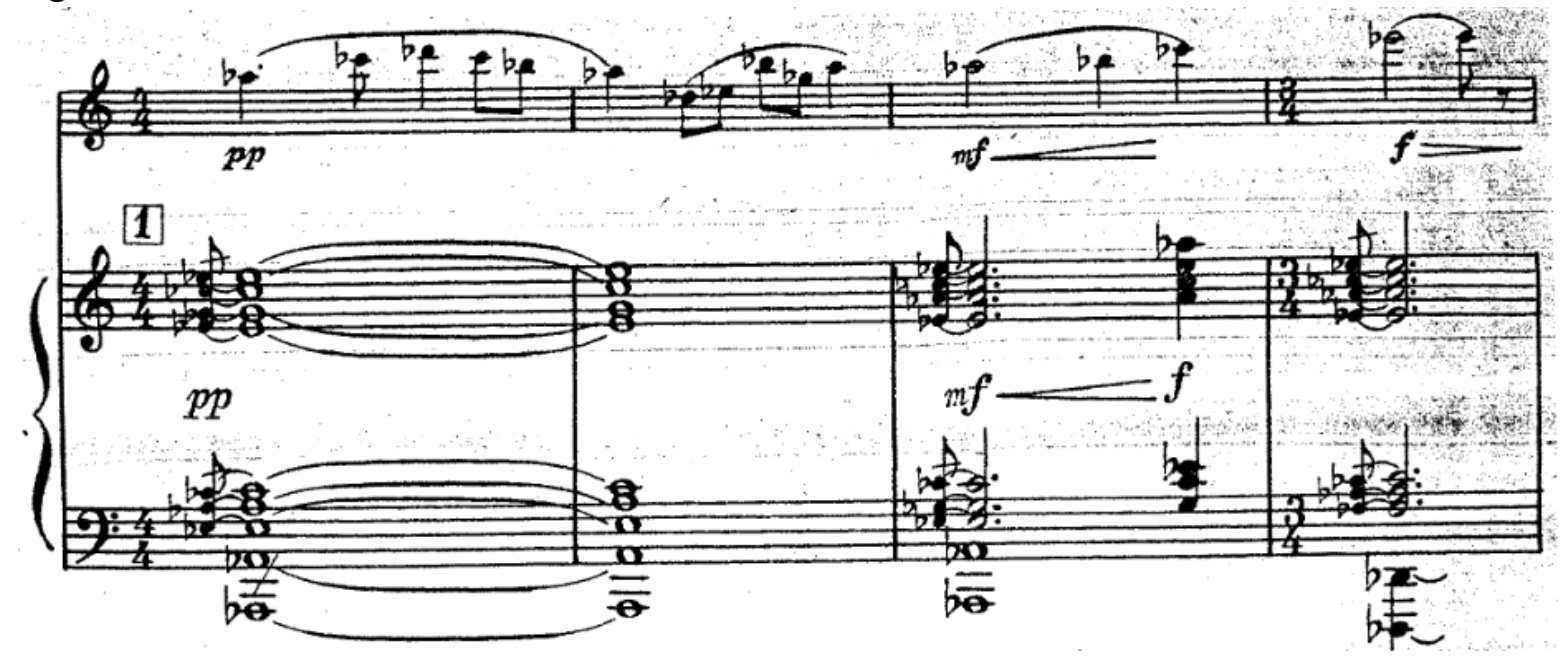

Fig. 42 - Poulenc, Oboe Sonata, Mvt. III, reh. 2

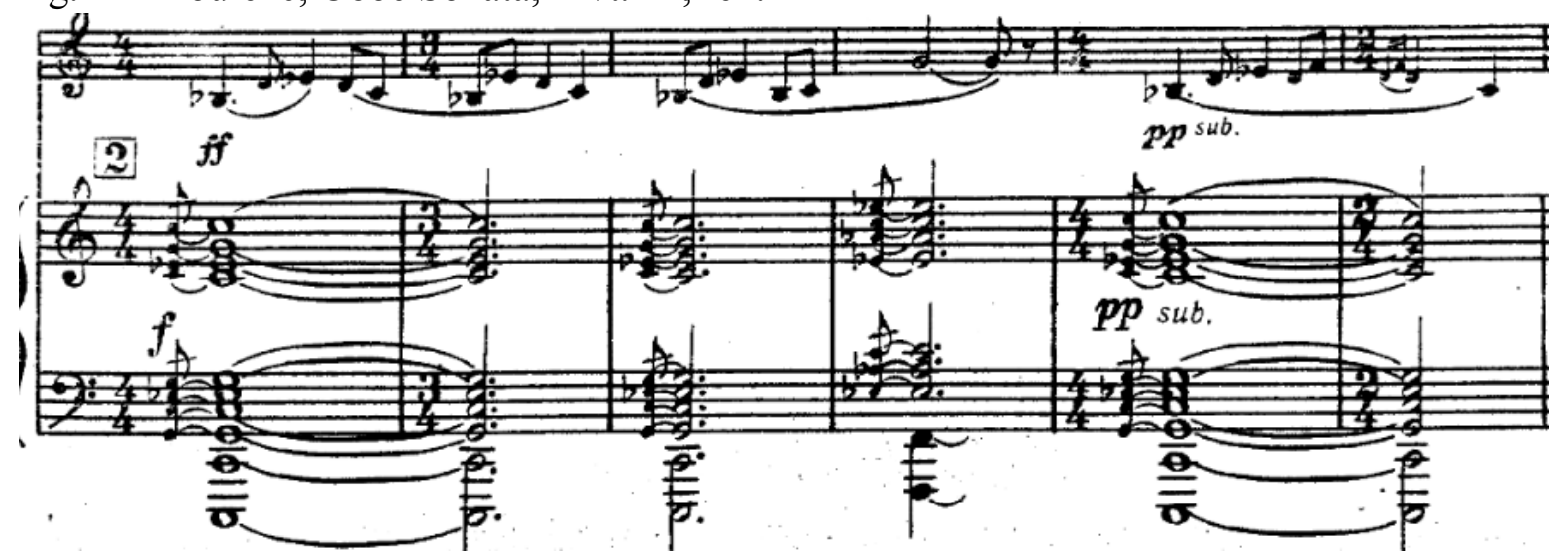

The return of A at reh. 7 signals the end of the piece. Daniel suggests a "dirge-like coda" 260 exists at reh. 8. I agree with him, as this music is new and serves no other purpose than to balance out the rest of the movement. In closing, Daniel and Grant give descriptive accounts of the profound message Déploration leaves with the listener. It is a liturgically-inspired

${ }^{260}$ Daniel, 253. 
movement where the oboe plays in pairs — soprano and bass, cantor and choir — all while eliciting religious imagery associated with the Church.

After performing the comparative analyses on the sonata, certain unifying characteristics become transparent in the place of traditional forms - self-quotation, direct references to Prokofiev through the observed recycled material, ambiguous tonal centers, fragmentation, and the "oboe as voice." The sonata deviates from expected traditional structures, preferring S-F-S and ABA ternary form over F-S-F and sonata form; there is no exposition or development of any kind in the work. Instead, they are replaced by fragments. Sectionalism does not exist in the sonata either; rather, fragmentation is used thematically and to great effect when selected parts return at important moments in the third movement. Grant reinforces this idea "that Poulenc ignores most if not all of the typical sonata conventions [and it] is not even as interesting as the fact that he chose this particular medium to express such profound, conflicting emotions." ${ }^{261}$ The extramusical elements are inspired from the dedication, Dies irae, and centuries-old French traditions like déploration. Daniel makes the observation that "Poulenc's chamber music was his most consistent genre, for he composed it in every decade and the stylistic characteristics (though not the mood) changed little from the works of the 1920s to those of the 1960s." ${ }^{262}$ The oboe sonata proves the opposite, that "mood and spirit" can serve as a thematic and extramusical expression on the form. Poulenc experimented within these fixed formal traditions yet created a work that alludes to something entirely new. I'm left to wonder, what would the bassoon sonata have sounded like?

\footnotetext{
${ }^{261}$ Grant, 104.

262 Daniel, 254.
} 


\section{Chapter 4}

\section{A Lasting Legacy}

Poulenc's sonatas are a hallmark of concerts, frequently featured on recital programs everywhere. His contribution to the chamber music genre is substantial, as seen through the large body of works he left behind. They are accessible, mostly tonal, and combine elements of high art with Parisian "street music." They evoke a sense of nostalgia from the listener and are often described as neoclassic. In the later works, he combines styles from his different eras to create a truly unified form that is unmistakably "Poulenc." His influence on the oboe spans from his first real solo setting of the instrument in the Trio for oboe, bassoon, and piano (1926). Ciulla, bringing attention to Jean Françaix’s Trio for oboe, bassoon, and piano (1994), claims that Poulenc was the driving inspirational force that helped composers in the later half of the twentieth century refine and further explore the neoclassical style.

\section{The Neoclassic Expectation}

The spirit of French innovation is driven by what Trickey identified as "youthfulness." It acts as a moving force marking periods of revolution and reaction. So it stands to reason that the generation of composers after Les Six came to such an impasse just like their predecessors. One of these composers, Jean Françaix, was born to musician parents in 1912 in Le Mans, France. His mother was a vocalist and his father "was an accomplished musicologist, composer, and pianist as well as the Director of the Le Mans Conservatoire."263 Family connections to Paris provided Françaix early lessons with Nadia Boulanger, the famous composition instructor.

${ }^{263}$ Ciulla, 21. 
Boulanger played a pivotal role in his childhood education and even gave many of his early premieres. ${ }^{264}$ Boulanger was impressed with him, remarking to his mother, "Madam, I do not know why we are wasting time to teach him harmony, he knows harmony. I do not know how, but he knows it, he is born knowing it." ${ }^{265}$ By 1930, he won the premier prix in piano performance at the Conservatoire.

Françaix's beginnings mirror Poulenc in a way—-they both had a musician parent(s) that was instrumental in getting them started and a famous mentor who premiered their first pieces. Poulenc thought highly of him when he said, "Only the kind of mediocrity that prevails today could so easily brush aside Stravinsky, Prokofiev, Hindemith, Falla etc... Apart from Francaix and Messiaen, all the young composers are quite happy with what was done before 1914."266 Poulenc expressed how dissatisfied he was with his contemporaries being unable to innovate, suggesting there was no need to improve on anything that came before 1914 (roughly the time Le Sacre du printemps was being performed at Théâtre des Champs-Elysées). He suggested that Françaix and Messiaen were the only ones of their generation that were attempting to revolutionize music. Poulenc and Françaix’s paths crossed frequently, and on several of these occasions they performed together. They played Poulenc's Concerto for Two Pianos when Février was not available (the same Février from Prokofiev’s Bridge tournaments). Another time, Poulenc offered him work when he was overbooked—-the publisher Hansen asked Poulenc to orchestrate his own piece L'histoire de Babar so he passed it on to Françaix. ${ }^{267}$ Hilarity ensued when Poulenc "allowed him to have a harp instead of piano, as well as a

\footnotetext{
${ }^{264}$ Ciulla, 21.

${ }^{265}$ Ibid.

${ }^{266}$ Nichols, 158.

${ }^{267}$ Ibid., 277.
} 
trombone or tuba which, as envisaged by Francaix, duly contributed 'some farts in the right places.' Poulenc called the result a chef d'oeuvre."268

Similarities in Françaix and Poulenc's music are abundant. Notably, they chose classical forms as starting points for experimentation and expression, their harmonic language was mostly tonal, and their treatment of solo winds as vehicles to deliver a "mood and spirit" is present. Ciulla's analysis of Françaix's Trio reaffirms the neoclassic nature of the work and the audience's approving reception. She mentions how his music allows for a more pleasurable experience when compared to his contemporaries:

"In classical music, you enter one room, then another, take a walk in the garden and return. With this new music you are locked in one room." This quote is vital to understanding Jean Françaix's approach to his formal structures as it provides a window into his mentality towards music that is both intelligible and pleasurable. ${ }^{269}$

In both the Poulenc and Françaix trios, she reviews the formal structure, harmonic devices, thematic material, rhythm and meter, and ensemble orchestration. She presents her findings as contemporary neoclassical examples. Ciulla provides a brief conclusion that directly relates to the influence:

When comparing the elements of composition, the two trios share many similarities. Each trio utilizes traditional forms while occasionally departing and distorting them. Harmonically, although they both employ techniques such as planing and chromaticism, the trios are tonal, usually beginning and ending in the same key area and remaining around a general tonal center. The use of orchestration is similar in both trios, often with the main thematic material in the oboe and bassoon, while the piano is accompanimental. ${ }^{270}$

Poulenc's oboe sonata displays these exact ideas: it takes the sonata and experiments with the form using fragmentation, it is mostly tonal while suggesting harmonic ambiguity, the B

\footnotetext{
${ }^{268}$ Nichols, 277.

${ }^{269}$ Ciulla, 25-26.

${ }^{270}$ Ibid., 38.
} 
section of the Scherzo is overly chromatic (as mentioned in Grant's observation), and the piano plays a pivotal role in both introducing important thematic material like the "c" section of the Élégie and accompaniment. Ciulla's concluding observations are concise, and her observations have serious implications on newly-composed wind sonatas. Neoclassical style creates expectations, which then poses many questions when approaching these works:

How does the form deviate from sonata form or the traditional form it uses? How does the handling of tonal centers affect the harmonic language of the work? How does orchestration decide important thematic presentations?

If extramusical influences are present, how do they impress on the form, tonal language, and thematic material?

Do performance instructions suggest any extramusical elements?

The allure of neoclassical compositions, with their feeling of classical familiarity, leaves them to be easily understood and received. On the surface, they indicate a return to traditional forms, but underneath they deviate from these fixed models greatly. They provide a veiled complexity brought forth by the spirit of experimentation and youthfulness. The continued innovation of these older models suggests there are still many more ways to explore them. As Grant said, "Poulenc ignores most if not all of the typical sonata conventions," 271 proposing that he was already pushing sonata form to its neoclassical limits towards the end of his life. His thematic recycling process from the flute and clarinet sonatas helped expedite the procedure, even abandoning exposition and development entirely in favor of fragmentation. Françaix's trio, as influenced by Poulenc, continues this concept of contemporary neoclassicism and reinvention of the style.

${ }^{271}$ Grant, 104. 


\section{Oboe Characterizations}

Neoclassic settings for the oboe present many performance opportunities. As seen through the lens of the oboe sonata, the oboe is characterized in three major different settings: the “oboe as voice," "oboe as virtuoso," and "oboe as tonality."

\section{Oboe as Voice}

Throughout the sonata, extramusical elements heavily suggest the oboe personifying the voice. This happens in all three movements, most prominently in the third movement as Grant provided concrete evidence of the "cathedral scene" and the responsorial choral settings. In the Élégie, the oboe first displays vocal tendencies at rehearsal four in the "c" section (Fig. 19). The obscured Dies irae at rehearsal six (Fig. 23) reveals further extramusical inspiration taken from liturgical chant. In the B section of the Scherzo (Fig. 36), Poulenc inserted a song into the middle of the movement.

\section{Oboe as Virtuoso}

The second and most traditionally observed characterization of the oboe is its virtuosic presentation in the Scherzo. Poulenc drew inspiration from Prokofiev and set the oboe as if it were the right hand of the pianist. If the oboe were removed from the A sections, the listener can more readily imagine Nichol's sparkling depiction of Prokofiev's piano playing. Poulenc's treatment of the oboe is then that of a pianist and not of a wind player, suggesting a different approach to articulation and dynamic phrasing.

\section{$\underline{\text { Oboe as Tonality }}$}

The oboe sonata opens in an ambiguously tonal way that foreshadows the uncertainty of the sonata's harmonic centers (Fig. 16). At key points, Poulenc used the oboe as a thematic tonal 
device to reaffirm this message, both in the beginning and ending of the Élégie, and the ending of the Déploration. He also did this at the beginning of the Romanza of the clarinet sonata (Fig. 17). Poulenc included the woodwinds in the overall discussion of his harmonic language, which signaled a certain "mood and spirit" of extramusical significance upon the work. 


\section{Chapter 5}

\section{Conclusions}

The comparative analysis reveals significant discoveries in Poulenc's oboe sonata. The work is rife with extramusical elements that impress on the total form of the work and its complete abandonment of sonata form. The presence of ABA ternary form in each movement indicates another thematic element that is not yet realized. Investigations into the self-quotations of the flute and clarinet sonatas led me to the discovery of the haunting flute melody from the Moderato tranquillo of Prokofiev's Romeo and Juliet Suite No. 2. Additionally, Grant's findings of the Dies irae have major implications on the secular nature of the work, as there are numerous other references that allude to the Church, too.

The review of biographical information sheds light on Poulenc's early relationships and influences found in the sonata. This provides context for the creation of the work, explains the dedication, and gives way to the encoded thematic elements.

The presence of Les Six is felt though never directly identified. Poulenc himself said they shared no compositional ideologies apart from the group's treatment of melody. The survey of their solo oboe works gives a brief overview of the different traditional forms they each composed and places Poulenc's sonata on that timeline with them. Trickey suggests that they did share some aesthetic principles, albeit only contextually. These principles reappear in Poulenc's sonata through the spirit of innovation and youthfulness "sans complexes."

By observing the Poulenc and Françaix's trios, a continuation of neoclassical idioms established by Poulenc can be seen in the contemporary era. Ciulla's investigations into Françaix's trio reveals this "Poulencien" influence, proposing that neoclassical expectations exist 
for newly-composed works that are considered the "sonata" or chamber works using traditional models. And should a musician want to realize a more truthful performance of these neoclassical works, including Poulenc's oboe sonata, it is important to address the expectations of neoclassical's deviation from the traditional style.

In closing, it has been almost sixty years since the death of Poulenc, and his presence is still felt today. With his final work, the oboe sonata, he explored the limits of the neoclassical style while glancing back for inspiration. In his last months, he returned to simplicity and traditional forms, while garnishing his harmonic language with a dash of his refined later style. His flavor was a complex recipe of many different ingredients from his youth that he seasoned over time. This is the reason his music is considered undeniably and irrevocably "Poulenc." 


\section{Bibliography}

Blacc, Guillaume and Romain Wacziarg. Explorations in Economic History. Vol. 78, Change and Persistence in the Age of Modernization: Saint-Germain-d'Anxure, 1730-1895. Amsterdam: Elsevier, 2020.

Ciulla, Siobhán Marie. "Two Examples of Neo-Classicism in France from the Early and Late Twentieth Century: Francis Poulenc's Trio for Oboe, Bassoon, and Piano (1926) and Jean Françaix's Trio for Oboe, Bassoon, and Piano (1994)." DMA diss., The Florida State University, 2017. ProQuest Dissertations and Theses Global.

Conquest, Robert. "Victims of Stalinism: A Comment."

Europe-Asia Studies 49, no. 7 (1997): 1317-19. http://www.jstor.org/stable/154087.

Daniel, Keith William. "Francis Poulenc: A Study Of His Artistic Development And His Musical Style." PhD diss., State University Of New York At Buffalo, 1980. ProQuest Dissertations and Theses Global.

Davies, R. W., and S. G. Wheatcroft. Industrialisation of Soviet Russia. Vol. 5, Years of Hunger: Soviet Agriculture, 1931-1933. London: Palgrave Macmillan, 2010.

Duteurtre, Benoît. La Mort de Fernand Ochsé. Paris: Fayard, 2017.

Grant, Margaret J. "A Feminist Analysis Of Francis Poulenc's Sonata For Oboe And Piano." DMA diss., University Of Cincinnati, 2006. ProQuest Dissertations and Theses Global.

Haynes, Michael, and Rumy Hasan. A Century of State Murder?:

Death and Policy in Twentieth-Century Russia. London: Pluto Press, 2003.

Homme, James Michael. "The Oboe Music of 'Les Six'." DMA diss., University of Maryland, College Park, 2019. ProQuest Dissertations and Theses Global.

Mellers, Wilfrid H. Francis Poulenc. Reprint, Oxford Studies of Composers. Oxford: Oxford University Press, 2003.

Nichols, Roger. Poulenc: A Biography. New Haven: Yale University Press, 2020.

O'Shea, Gary. "Prokofiev's Early Solo Piano Music." PhD diss., University of Sheffield, United Kingdom, 2013. ProQuest Dissertations and Theses Global.

Poulenc, Francis. Dialogues de Carmélites. Milan: Ricordi, 1957.

Poulenc, Francis. La voix humaine. Paris: Ricordi, 1959. 
Poulenc, Francis. Sonata for Clarinet and Piano. Rev. ed. London: Chester, 2006.

Poulenc, Francis. Sonata for Flute and Piano. Rev. ed. London: Chester, 1994.

Poulenc, Francis. Sonata for Oboe and Piano. Rev. ed. London: Chester, 2004.

Poulenc, Francis, and Stéphane Audel. My Friends And Myself: Conversations [With] Francis Poulenc. Translated by James Harding. London: Dobson Books Ltd., 1978.

Poulin, Pamela Lee. "Three Stylistic Traits in Poulenc's Chamber Works For Wind Instruments." PhD diss., University of Rochester, Eastman School of Music, 1983. ProQuest Dissertations and Theses Global.

Prokofiev, Sergei. Piano Sonata No. 4, Op. 29. Moscow: A. Gutheil, 1917.

Prokofiev, Sergei. Piano Sonata No. 5, Op. 38. Moscow: A. Gutheil, 1925.

Prokofiev, Sergei. Romeo and Juliet Suite No. 2, Op. 64ter. 1936. Reprint, New York: E.F. Kalmus, 1970.

Schmidt, Carl B. Entrancing Muse: A Documented Biography of Francis Poulenc. Hillsdale: Pendragon Press, 2001.

Sitton, Michael Randy. "The Album Des Six and Pianism in the Works of Les Six, 1917-1925." DMA diss., University of Illinois at Urbana-Champaign, 1991. ProQuest Dissertations and Theses Global.

Trickey, Samuel Miller. "Les Six." PhD diss., University of North Texas, 1955. ProQuest Dissertations and Theses Global. 